\title{
Prevention of lower respiratory tract infection in mechanically ventilated patients : study of the effect of a novel regime of selective decontamination in combination with short-term systemic antibiotic prophylaxis
}

Citation for published version (APA):

Aerdts, S. J. A. (1989). Prevention of lower respiratory tract infection in mechanically ventilated patients : study of the effect of a novel regime of selective decontamination in combination with short-term systemic antibiotic prophylaxis. [Doctoral Thesis, Maastricht University]. Rijksuniversiteit Limburg.

https://doi.org/10.26481/dis.19890217sa

Document status and date:

Published: 01/01/1989

DOI:

$10.26481 /$ dis.19890217sa

Document Version:

Publisher's PDF, also known as Version of record

Please check the document version of this publication:

- A submitted manuscript is the version of the article upon submission and before peer-review. There can be important differences between the submitted version and the official published version of record. People interested in the research are advised to contact the author for the final version of the publication, or visit the DOI to the publisher's website.

- The final author version and the galley proof are versions of the publication after peer review.

- The final published version features the final layout of the paper including the volume, issue and page numbers.

Link to publication

\footnotetext{
General rights rights.

- You may freely distribute the URL identifying the publication in the public portal. please follow below link for the End User Agreement:

www.umlib.nl/taverne-license

Take down policy

If you believe that this document breaches copyright please contact us at:

repository@maastrichtuniversity.nl

providing details and we will investigate your claim.
}

Copyright and moral rights for the publications made accessible in the public portal are retained by the authors and/or other copyright owners and it is a condition of accessing publications that users recognise and abide by the legal requirements associated with these

- Users may download and print one copy of any publication from the public portal for the purpose of private study or research.

- You may not further distribute the material or use it for any profit-making activity or commercial gain

If the publication is distributed under the terms of Article $25 \mathrm{fa}$ of the Dutch Copyright Act, indicated by the "Taverne" license above,

Download date: 26 Apr. 2023 
PREVENTION OF LOWER RESPIRATORY TRACT INFECTION IN MECHANICALLY VENTILATED PATIENTS 
Tekening omslag: Willemijn Aerdts

No part of this book may be reproduced in any form, by print, photoprint or any other means without written permission from the publisher.

Niets uit deze uitgave mag worden verveelvoudigd en/of openbaar gemaakt door middel van druk, fotokopie, microfilm of welke andere wijze dan ook, zonder voorafgaande toestemming van de uitgever.

Text and data have been processed with Framework, Ashton-Tate. 


\section{PREVENTION OF LOWER RESPIRATORY TRACT INFECTION IN MECHANICALLY VENTILATED PATIENTS}

Study of the effect of a novel regime of selective decontamination in combination with short-term systemic antibiotic prophylaxis

\section{PROEFSCHRIFT}

TER VERKRIJGING VAN DE GRAAD VAN DOCTOR AAN DE RIJKSUNIVERSITEIT LIMBURG TE MAASTRICHT. OP GEZAG VAN DE RECTOR MAGNIFICUS, PROF. DR. F.I.M. BONKE, VOLGENS BESLUIT VAN HET COLLEGE VAN DEKANEN

IN HET OPENBAAR TE VERDEDIGEN OP VRIJDAG, 17 FEBRUARI 1989 OM 14.00 UUR

door

STANISLAUS IACOBUS ANTONIUS AERDTS geboren te Venlo in 1956 


\title{
PROMOTOR:
}

Prof. Dr. C.P.A. van Boven

\author{
BEOORDELINGSCOMMISSIE: \\ Prof. Dr. P.G. Knipschild \\ Prof. Dr. C.E. Blanco \\ Prof. Dr. I.McA. Ledingham \\ Prof. Dr. O.C.K.M. Penn \\ Prof. Dr. P. B. Soeters \\ Prof. Dr. J. Verhoef
}

This study was carried out at the Intensive Care Unit of the Nijmegen University Hospital under supervision of: R. van Dalen, MD and H.A.L. Clasener, MD, PhD.

This study was supported by educational grants from: Roussel b.v., Hoevelaken, The Netherlands and Roussel-UICLAF, Paris, France. 
Aan Piep. Willemijn en Tim 


\section{Abbreviations}

DFI Dutch Florin

ICU Intensive Care Unit

MCR Microbial Colonization Resistance

MIC Minimum Inhibitory Concentration

PCR Physiological Colonization Resistance

PTA Polymyxin E, Tobramycin and Amphotericin B

SDD Selective Decontamination of the Digestive tract

Author"s present address:

Department of internal medicine

Canisius-Wilhelmina Hospital

P.B. 9015

6500 GS Nijmegen

The Netherlands
Future address (from summer 1989):

Department of intensive care medicine The Nijmegen University Hospital P.B. 9101 6500 HB Nijmegen

The Netherlands 


\title{
Table of contents
}

\author{
Introduction
}

Chapter I Microbial colonization resistance of the digestive tract:

clinical implications

The flora of oropharynx and lower digestive tract 5

Colonization resistance of the lower digestive tract 6

Microbial colonization resistance and antibiotic policy 7

Selective decontamination of the digestive tract $\quad 10$

References 1 I

Chapter II Lower respiratory tract infection in mechanically ventilated patients: pathogenesis and possible modes of prevention $\quad 13$ $\begin{array}{ll}\text { Introduction } & 13\end{array}$

$\begin{array}{ll}\text { Etiology } & 13\end{array}$

$\begin{array}{ll}\text { Pathogenesis } & 14\end{array}$

$\begin{array}{ll}\text { Colonization of the oropharynx } & 15\end{array}$

$\begin{array}{ll}\text { Colonization of the stomach } & 17\end{array}$

Sources of microorganisms colonizing oropharynx $\begin{array}{ll}\text { and stomach } & 17\end{array}$

$\begin{array}{ll}\text { Prevention } & 19\end{array}$

Selective decontamination of the digestive tract 20

$\begin{array}{ll}\text { References } & 21\end{array}$

Chapter III Selective decontamination and short-term systemic antibiotic prophylaxis in mechanically ventilated patients: study design

Aims of the study $\quad 25$

Study design $\quad 25$

Justification of the regime used $\quad 27$

$\begin{array}{ll}\text { References } & 32\end{array}$

Chapter IV Selective decontamination and short-term systemic antibiotic prophylaxis in mechanically ventilated patients: results of the colonization study $\quad 35$

Results of the colonization study 35

Discussion $\quad-48$

Conclusion $\quad 51$

References $\quad 52$ 
Chapter V Selective decontamination and short-term systemic antibiotic prophylaxis in mechanically ventilated patients: clinical results

Results

Discussion

Conclusion

References

Chapter VI Selective decontamination and short-term systemic antibiotic prophylaxis in mechanically ventilated patients: cost-effectiveness analysis 65

Introduction 65

Methods 66

Results 67

Discussion 70

Conclusion 72

References

Summary and general discussion

Samenvatting en discussie

Dankwoord 


\section{Introduction}

The incidence of infection in patients treated in Intensive Care Units (ICU's) is high [Donowitz, 1982; Daschner, 1982; Chandrasekar, 1986]. In patients admitted for five days or more, the incidence of unit acquired infection may exceed $70 \%$ [Stoutenbeek, 1984; Kerver, 1987].

In patients requiring prolonged intubation and mechanical ventilation, infections of the lower respiratory tract are particularly troublesome and occur in about $60 \%$ of the cases [Stoutenbeek, 1984: Kerver, 1987].

Once a cycle of lower respiratory tract infection, reduced host defense, septicaemia and organ failure is established, conventional management is clearly inadequate and mortality may exceed $50 \%$ [Stevens, 1974; Watt, 1984]. This stresses the need for adequate prevention of infection.

Early lower respiratory tract infections, that occur in the first days after admission, are frequently caused by microorganisms that are part of the commensal oropharyngeal flora. However, late infection, chiefly caused by Gram-negative bacilli, constitutes the main problem.

Gram-negative bacilli, which hardly ever colonize the oropharynx or stomach of healthy individuals, frequently colonize these sites in critically ill patients. By aspiration of small quantities of oropharyngeal or gastric contents past the cuff of the endotracheal tube - a frequent event in mechanically ventilated patients - these microorganisms spread to the lower airways, and infection may result. In this sequence of events, the occurrence of microbial colonization of oropharynx and stomach plays a pivotal role [Johanson, 1984].

It is reasonable to postulate that prevention of colonization of oropharynx and stomach might provide prophylaxis against mechanical ventilation associated pneumonia. However, until recently, attempts to eliminate colonization by the administration of antibiotics failed and resulted in colonization with new, resistant, strains of bacteria.

In the 1970's it became clear that the autochthonous anaerobic flora of the digestive tract plays an important role in the prevention of colonization of the digestive tract with Gram-negative bacilli [Clasener, 1987]. This concept did not only explain the development of colonization and super-infection with resistant strains which follows the use of those antibiotics which disturb the anaerobic intestinall flora, but also resulted in the development of Selective Decontamination of the Digestive tract (SDD) as a novel method of infection prevention. This technique implies the application of antibiotics to the digestive tract. The antibiotics used eliminate Gram-negative bacilli and yeasts from the gastrointestinal iract, but do 
not affect the anderobic fora, so leaving the limiting effect that parts of this anacrobic flora have on the growth of acrobic microorganisms intact [Van der Waij, 1974 J. SDD has already proved effective in the prevention of infection in neutropenic patients.

In 1984. SDD, in combination with short-term systemic antibiotic prophylaxis, was first shown to reduce the incidence of lower respiratory tract infection in mechanically ventilated patients [Stoutenbeek, 1984]. However, in this study as well as in others Kunnen, 1989; Ledingham, 19881, the infection rates were compared to those in historical control groups. Furthermore, the experience was limited to the use of one regime of SDD.

In this thesis the results of a prospective, randomized study of the effect of a novel regime of SDD will be presented. The regime of SDD consisted of norfloxacin, polymyxin E and amphotericin B in combination with short-term systemic cefotaxime prophylaxis and was applied to patients that were mechanically ventilated for at least five days. The incidence of microbial colonization of the oropharynx and of the stomach, and the incidence of lower respiratory tract infection in a group of patients receiving this regime, were compared with the incidences in two control groups. In neither of the two control groups the patienis received antibiotic prophylaxis; antibiotics were administered only in case of clinical evidence of infection. However, in the lirst control group infections were treated with antibiotics which affect the autoch thonous anaerobic fllora, whereas in the second control group the use of antimicrobial agents was confined to agents which lack this effect, such to evaluate the effect of two different policies of antibiotic therapy on the incidence of colonization and infection.

In chapter I, the concept of an anaerobic intestinal flora which limits the growth of aerobic microorganisms will be elucidated, as will be the clinical consequences of this concept.

In chapter II. the literature on the pathogenesis and prevention of lower respiratory tract intection in mechanically ventilated patients will be reviewed.

In chapter III the design of out study will be specified.

In chapler IV, colonization of oropharynx, stomach and rectum in the three groups will be described, as will be the role this colonization played in the development of lower respiratory tract inlection.

In chapter $\mathrm{V}$, the clinical results are given, with the emphasis on lower respiratory tract infection.

Chapter VI provides a cost-elfectiveness analysis of the use of our regime of SDD in mechanically ventilated patients. 


\section{References}

Chandrasekar PH. Kruse JA. Mathews MF. Nowocomiall infections among pationts in difterent types of intensive care units al a cily hospial. Crit Care Med 1986: 14:508-10.

Clasener HAL. Vollaard EJ. Van Saene HKF. Long-lom prophylaxis of infection by selective decontamination in leucopentan and in mechanical wentilation. Rev Infect Dis 1987: 9:245-3248

Daschner FD. Frey P. Wolf G. Bamann PC. Suter P. Nowocomial infections in intensive care wards: a multicenter prospecive study. Intensive Care Med 1982:8:5.9.

Donowizz LG. Wenzel RP. Hoyt JW. High rish of hospital-acquired infection in the ICU pattient. Crit Care Med 1982: 10:355-7.

Johanson WG. Prevention of respiratory tract infection. Am J Med 1984; 76 (Suppl 5it); 69-77.

Kerver AJH, Rommes JH, Mevissen Verhage EAF. et all. Colonization and infection in surgical intensive care partents: a prospective study. Intensive Care Med 1987: 13:347-51.

Kunnen HJ. Krikken J, Van Saene HKF. Significant roduction of infection related morbidity and mortality by proplinylactic flora suppression in long stay intensive care unit patients: a prospective consecutive study. Crit Care Med. In press.

Ledingham IMCA. Alcock SR. Eastaway AT. MCDonald JC. MCKany IC, Ramsay G. Triple regimen of selective decontmination of the digestive trat, systemic cefotaxime, and microbiological surveitlance for prevention of incquired infection in intensive care. Lancet 1988: i: 785-90.

Stevens RM. Teres D. Shillman JJ Feingold DS. Pheumonia in an intensive eare unit. Areh Int Med 1974: 134:106-11.

Stoutenbeck ChP. Van Saene HKF. Mirandat DR, Zandstra DF. The effect of selecive decontaminattion of the digestive tract on colonization and infection rate in multiple tratuma pattents. Intensive Care Med 1984: 10: 185-92.

Van der Wataj D. Berghuis-De Vries IM. Selective elimination of Entrobacteriaceate species from the digestive tract in miace and monkcys. J Hyg Camb 1974: 72: 205-11.

Watt I, Ledingham IMCA. Mortality anongst multiple trama parients admited to in intencive therapy unit. Anacshesia 1984; 39: 677-81. 



\section{Microbial colonization resistance of the digestive tract: clinical implications}

In the last fifteen years it has become clear that parts of the autochthonous anaerobic intestinal flora play an important role in limitation of the growth of aerobic microorganisms in the digestive tract of man. This concept of a growth-limiting flora explains the occurrence of superinfections following the use of antibiotics that affect the anaerobic intestinal flora, and has far-reaching consequences for the antibiotic policy. This concept has further led to the development of Selective Decontamination of the Digestive tract (SDD), a novel technique of infection prevention.

This important development, that has recently been reviewed by Clasener et al. will be summarized in this chapter [Clasener, 1987].

\section{The flora of oropharynx and lower digestive tract}

Bacterial microorganisms can be categorized in many different ways. According to the role microorganisms play in the etiology of $\mathrm{ICU}$-acquired infection, we divided microorganisms colonizing the intestinal tract of man into the following three categories:

\section{Autochthonous flora}

This flora, that is present in all individuals, consists mainly of anaerobic microorganisms, which are present in high concentrations $\left(10^{7-4} / \mathrm{m} /\right.$ salliva in the oropharynx and $10^{9-11} / \mathrm{g}$ faces in the tower digestive tract). The anacrobic flora not only has important physiological functions (Mackowiak, 1982), it also contributes to the defense against colonization of the digestive tract by aerobic microorganisms [Van der Waaij, 1977]. Anaerobic microorganisms have a low pathogenicity: although the number of anaerobic microorganisms in oropharynx and lower digestive tract is about 1.000 .000 times greater than the number of aerobes, anaerobic infections are rare compared to aerobic infections.

\section{Commensalffora}

This flora consists of aerobic microorganisms that, although not always present, are considered to be normal inhabitants of the oropharynx, or of the lower digestive iract. The most frequent commensal bacteria in the oropharynx are: Sirepro- 
coccus viridans. Hacmophilus influenzae. Streptococcus pneumoniae. Staphylococcus aureus and Branhamella catarrhalis. The most important members of the commensal flora of the lower digestive tract are Escherichia coli and Enterococcus faeculis. Commensal microorganisms play an important role in the etiology of community-acquired infections, and also in the etiology of infections acquired in the first days of admission at the ICU [Stoutenbeek, 1987; RuizSantana, 19871.

\section{Gram-negative bacilli}

Gram-negative bacilli hardly ever colonize the oropharynx of healthy individuals [Johanson, 1969], and Grammegative bacilli other than E.coli are only seldom present in the digestive tract in concentrations above the limit of detection $\left(10^{2}\right.$ microorganisms/g faeces). However, hospitalized patients - even if only moderately ill - frequently acquire Gram-negative bacilli in their oropharynx [Johanson, 1969]. In the lower digestive tract of hospitalized patients, E.coli is often supplanted by non-coli bacilli as predominant Gram-negative bacilli [Le Frock, 1979]. Gram-negative bacilli are responsible for more than 50 percent of the infections in the ICU [Massarani, 1986], and for more than 80 percent of the infections occurring after the first week of admission [Stoutenbeek, 1987]. Gramnegative bacillary colonization of oropharynx and stomach, and non-coli bacillary colonization of the lower digestive tract is the initial step in virtually all these inlections.

Commensal flora and Gram-negative bacilli together are responsible for almost all infections at the ICU. Microorganisms from these two categories will be referred to as potentially pathogenic microorganisms.

In the present chapter, factors influencing colonization of the lower digestive tract will be reviewed. Understanding of these factors is important, because Gramnegative bacillary colonization of the lower digestive tract is a major source of infection as well as of cross-infection |Selden,1971]. Furthermore, the lower digestive tract is probably the most important ecological niche in the human body where resistant microorganisms are selected and where resistance against antibiotics is transferred by cell-10-cell contact. [Van der Waaij, 1982].

\section{Colonization resistance of the lower digestive tract}

Working with germ-free animals, Van der Waaij et al found that an organism such as Escherichia coli would colonize the alimentary canal when as little as 10 to 100 microorganisms were given orally. On the contrary, conventional animals required about $10^{7}$ or more organisms via oral inoculation for the digestive tract to be colonized. This indicates that the intestinal flora has the capacity to prevent 
collonization by new organisms. This capacity was originally called Colonization Resistance [Van der Waaij, 1971;1979]. Subsequent studies in mice and man learned that the microorganisms responsible for colonization resistance are part of the anaerobic flora [Van der Waaij, 1977]. Not much more is known about the limiting flora in man, except then that it is obligatory anaerobic, and that it is probably associated with the mucus of the large intestine. There are probably several mechanisms by which the anaerobic flora limits the colonization by aerobes: shielding of mucosal receptors, production of toxic substances such as volatile fatty acids and competition for food. However, colonization resistance does not only depend on microbial factors, but also on physiological factors like peristalsis, secretion of mucus, secretion of immunoglobulin A, etc. We therefore used the term Microbial Colonization Resistance (MCR) for that part of colonization resistance that depends on the anaerobic flora.

\section{Microbial colonization resistance and antibiotic policy.}

From the beginning of the antibiotic era, superinfections have represented the failure of treatment that initially seemed successful: adequately instituted therapy eliminated the infecting microorganism, but this microorganism was suddenly succeeded by a resistant microorganism, usually of another species /Weinstein, 19771. Superinfections have occurred with considerable frequency after administration of penicillin (especially at higher dosages) [Tillotson, 1968], methicillin [Sabath, 1962], tetracycline [Louria, 1962], chloramphenicol [Louria, 1962]. and ampicillin [Price, 1970; Bingen, 1982].

The occurrence of superinfections during or after treatment with some antibiotics may be explained as follows. The administration of an antibiotic affecting that part of the anaerobic intestinal flora that is responsible for MCR, results in susceptible E.coli (normal concentration $10^{5} / \mathrm{g}$ of faeces) being replaced by resistant Gramnegative bacilli in a much higher concentration (usually $\pm 10^{9} / \mathrm{g}$ of faeces). This resistant Gram-negative bacillus may be an E.coli, but usually it is a Klebsiclla. Serratia, Enterobacter or Pseudomonas. These microotganisms may already be present in the intestine in low concentrations, but are also regularly supplied via the food or transmitted from other patients. In any case, a substantial increase in the number of resistant Gram-negative bacilli in the lower digestive tract occurs. This situation greatly increases the probability of superinfection.

Maintenance of the autochthonous anaerobic intestinal flora, and thus of MCR, seems the surest way of preventing colonization with resistant Gram-negative bacilli and thus super-infection. Therefore, it is advisable to use antimicrobial agents that do not affect MCR. Consequently all antibiotics should be tested for their influence on MCR.

Two factors determine the effect of an antimicrobial agent on MCR IVan der Waaij, 1982]. 
(1) The concentration of antibiotic at the site of the limiting anaerobic flora (presumably the mucus of the large intestine). This concentration conceivably is determined by the following factors:

a. the degree of resorption after oral antibiotic administration,

b. the degree and site (e.g. saliva, bile, mucus) of excretion of resorbed antimicrobial agents,

c. the degree and site of excretion of parenterally administered antimicrobial agents.

(2) The effect of the antimicrobial agent on that part of the anaerobic intestinal flora that constitutes MCR.

The fact that the composition of this flora is not exactly known, renders direct determination of the effect of antibiotics on this flora impossible. There are several indirect methods to determine this effect.

(1) The increase in the concentrations of Gram-negative bacilli in the lower digestive tract, together with the high incidence of superinfections in patients treated with some antibiotics, were the original indications that these antibiotics disturb the MCR. However, ats colonization resistance may already be reduced by underlying disease, patients are not very suitable to determine the effect of an antibiotic on the MCR.

(2) Animal experiments of the effect of antibiotics on MCR may yield more useful results than patient studies. An additional advantage of animal experiments is that they offer the possibility to perform a challenge test with bacteria resistant to the antibiotic tested. The challenge strain is administered both before and during antibiotic administration. If the rate of elimination of the challenge strain is not diminished by the administration of a certain dose of antibiotic, this antibiotic in this dose (and administered in this way) has no influence on MCR. However, it is difficult to extrapolate the dose of antibiotic used in animals to the dose used in humans.

(3) Therefore, challenge experiments in human volunteers are the method of choice to study the influence of antimicrobial agents on MCR and are now becoming an established procedure. A major difficulty in this approach is finding, for the use as challenge strain, Gram-negative bacilli that at the same time should be apathogenic, and resistant to the sometimes high faecal concentrations reached by the antibiotics to be tested.

The evidence presently available regarding the effect of some important antibiotics on MCR has recently been reviewed [Vollaard, 1989|. It is on this review that the tables I and II are based. 
Table I Antimicrobial agents and Microbial Colonization Resistance (MCR). The effect of intravenous administration.

\begin{tabular}{|c|c|c|}
\hline Anrimicrobial agent & Effect on $M C R$ & Remants \\
\hline $\begin{array}{l}\text { Penicillins } \\
\text { amoxicillin } \\
\text { ampicillin } \\
\text { azlocillin } \\
\text { isaxozolylpenicillins } \\
\text { penicillin G } \\
\text { piperacillin } \\
\text { ticarcillin }\end{array}$ & $\begin{array}{l}\text { disturbance } \\
\text { disturbance } \\
\text { disturbance } \\
\text { disturbance } \\
\text { disturbance } \\
\text { disturbance } \\
\text { disturbance }\end{array}$ & $\begin{array}{l}\text { e.g. Gucloxacillin, dicloxacillin. } \\
\geq 10^{\circ} \text { U tid, lower dose unknown. }\end{array}$ \\
\hline $\begin{array}{l}\text { Cephalosporins } \\
\text { cefotaxime } \\
\text { cefoxitin } \\
\text { cephradine } \\
\text { ceftazidime } \\
\text { celtriaxone } \\
\text { cefuroxime }\end{array}$ & $\begin{array}{l}\text { none } \\
\text { disturbance } \\
\text { none } \\
\text { none } \\
\text { disturbance } \\
\text { none }\end{array}$ & $\leq 750 \mathrm{mg}$ tid. higher doses disturb MCR \\
\hline
\end{tabular}

\section{Aminoglycosides}

All aminoglycosides

nune

\section{Quinolones}

ciprofloxacin

pefloxacin

none:

none:

\section{Otther agents}

chloramphenicol

disturbunoe

clindamycin

cotrimoxazole

distutbance

doxycycline

none

erythromycin

none

none

imipenem

unknown

lincomycin

disturbance

metronidazole

none

trimethoprim

none

vancomycin

mone

oral wancomycin soverely disturbs MCR 
Table II Antimicrobial agents and Microbial Colonization Resistance (MCR). The effect of oral administration.

No known effect on MCR Disturbing MCR

cefaclor

colistin*

cotrimoxazolet

doxycycline

erythromycin

metromidazole

nitrofurantoin

quinolones (all)

roxithromycin

tobramycin*

trimethoprim* aminoglycosides (all except tobramycin)

amoxicillin

ampicillin

clindamycin

isauxozolylpenicillins:

phenethicillin

tetracycline

vancomycin

* agents that maty be used for selective decontamination (mostly in combination whith oflaer agents).

\section{Selective decontamination of the digestive tract}

Antimicrobial agents that do not disturb MCR, can be administered safely, that is without increasing the risk of colonization and super-infection with resistant strains. This offers the opportunity to eliminate potentially pathogenic microorganisms from the digestive tract, without the risk of overgrowth by resistant microorganisms. The technique of eliminating potentially pathogenic microorganisms while leaving the autochthonous anaerobic flora intact has been named Selective Decontamination of the Digestive tract (SDD) [Van der Waaij, 1974]. Patients with cytostatic-induced leucopenia have such a serious reduction of resistance to infection that infections already develop with the normal concentrations of aerobic intestinal flora. Elimination of these potentially pathogenic microorganisms by means of SDD prevents infection in these patients [Sleijfer, 1980; Karp, 1987; Dekker, 1987].

More recently, the successful application of SDD has also been described in nonneutropenic patients, particularly in those patients whose physiological colonization resistance is disturbed by disease or by medical intervention (e.g. transurethral catheterization [Vollaard, 1989 | or endotracheal intubation [Stoutenbeek, 19841).

This thesis describes the effect of a regime of SDD - in association with short-term systemic antibiotic prophylaxis - on the colonization of the oropharynx and of the stomach with potentially pathogenic microorganisms and on the frequency of lower respiratory tract infection in patients requiring prolonged mechanical ventilation. 


\section{References}

Bingen $\mathbb{E}$. Lambert-Zechorsky $N$, Leluan $\mathrm{G}$, Deswignes A Influence do l'anpicilline associce aux aminosides sur l"écosystème bacterièn intestinal de l'enfant. Ann Pharm Fi" 1982: 40:269-80.

Clasener HAL: Vollatard El. Van Saene HKF. Long-term prophylaxis of infection by selective decomtamination in leucoperia and in mechanicall ventilation. Rev Infect Dis 1987: 9:295-328

Dekker AW, Rozenberg-Arska M. Verhoef J. Infection prophylaxis in acute leucemiat a comparison of ciprofloxacin with trimethoprim-sulfamethoxazole and colistin. Ann In Med 1987, 106: 7-12

Johanson WG. Pierce AK, Sanford JP. Changing pharyngeal flora of hospitalized patients. N Engl I Med 1969,281:1137-40.

Karp JE. Merz WG, Hendricksen C, et al. Orat morlloxacin for prevention of Gram-negative bacterial infections in patients with acute leveadmia and granufocylopenta. Am Int Med 1987; 106: 1-7.

Le Frock JL. Ellis CA, Weinstein L. The impact of hospitalization on the aerobic microllora. Am I Med Science 1979: 277: 269-74.

Louria DB, Kaminki T. The effects of four antimicrobial drug regimens on sputum superinfection in hospitalized patients. Am Rev Respar Dis. 1962; 85: 649-65.

Mackowiak PA. The normal microbial thora. N Engl J Med 1982; 307: 83-93.

Massitrani RM, Herhelzer WJ. The intensive care unit. In: Bennett IN, Brachman PS, cals. Hospitall infections. Boston: Little. Brown and company, 1986: 285-97.

Price DI. Sleigh JD. Control of infection due to Klebsiella aerogenes in a neurosurgical unit by with. drawal of all antibiotics. Lancet 1970; ii: $1213-5$

Ruiz-Santana S, Jimenez $\mathrm{AG}_{n}$ Esteban $\mathrm{A}$, ct at. ICU pneumonias: an malti-inditutional study Crit Cam Med 1987:15:930-2.

Sabath LD, Postic B, Finland M. Methicillin teatunent of severe staphylococcal disease. N Engl I Meat 1962:267: 1049-57.

Selden R. Lee S. Wang WLL. Bennet JV. Eickhorf TC. Nosucomial Klebsiella infections: intestimal collonization as a reservoir. Ann Int Med 1971: 74: 657-64.

Sleijler DT. Mulder NH. De Vries-Hospers HG. et al. Infection prevention in granulecylopenic pattients by selective decontamination of the digestive tract. Furop J Cancer 1980: 16:859-69.

Stoutenbeck ChP, Van Saene HKF, Mirandat DR, Zandstra DF. The effect of selective decontaminattion of the digestive trate on collonization and infection rate in multiple tratuma patients. Intensive Care Med 1984;10: 185-92.

Stoutenbeek ChP, Van Sitene HKF. Miranda DR, Zandstra DF. Langretr D. The elfeet of orophityngeal decontamination using topical nonabsorbable antibioties on the incidence of nosocomial nesporatory tact infections in multiple tramuma patients. I Trauma I987; 27: 357-64.

Tillotson JR. Finland M. Secondary pulmonary infections following antibiolic therapy for primary bacterial pnetumonias. Antimicrob Agents Chemother 1968: $326-30$.

Van der Waaj D. Berghuis-de Vries JM. Lekkerkenk-van der Wees JEC. Cohonization resistance of the digestive tract in conventional and antibiotic-1rexted mice. Hyg Camb 1971:69:405-11.

Van der Waaij D. Berghuis-De Vries JM. Selective climination of Entcrobacteriacene species froma the digestive tract in mice and monkeys. J Hyg Camb 1974: 72: 205. 11 .

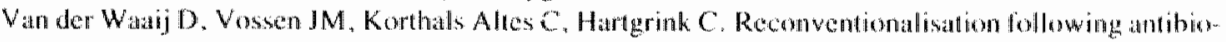
tic decontamination in man and anime's. Am I Clin Nurr 1977; 30: 1887.95 .

$V$ an der $W$ arij $D$. The colonization resistance of the digestive trace in experimental animals and its consequences for infection prevention. acquisition of new bacteria and the prevention of spread of bacteria between age mates. In: Van der Waij $D$, Verhoef J. eds. New critheria for antimicrobial the rapy: maintenance of digestive tract colonization resistance. Annsterdam: Exeerpta Medila. 1979: $43-53$.

$V$ an der Watj D. Colonization wesistance of the digestive tract anical conseguences atnd implications. J Antimicrub Chemother 1982: 10:263-70

Vollatad E. Clasener HAL. Van Saene HKF. Muller NFF. Effect on exolumization resistance an mopor. lant criterion in seleding antibiotics. Drug Intell Clin Pharm 1989, submitted. 
Vollatrd E. Clakener HAL. Zamban IV. Joesten HM. Van Cricthuyysen AJA. Prevention and treatment of catheter-astociated bacteriurid by selective decontamination and systemic antibiotic pro-

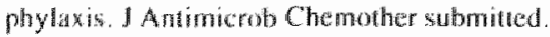

Weintatein L. Brown RB. Colonization, suprainfection and superinfection: major microbiologic and dinical problems. Me Sinai J Med $1977.44: 100-12$ 


\title{
Lower respiratory tract infection in mechanically ventilated patients
}

\author{
PATHOGENESIS AND POSSIBLE MODES OF PREVENTION
}

\section{Introduction}

Patients receiving mechanical ventilation are at high risk of developing lower respiratory tract infection. This risk increases when mechanical ventilation is prolonged. In several studies, the incidence of respiratory tract infection increased to $50 \%$ or more after the first week of mechenical ventilation [Cross, 1981; RuizSantana, 1987; Stoutenbeek, 1984; Kerver, 19871.

Respiratory tract infection in critically ill patiens is associated with a considerable increase in morbidity. It is followed by secondary septicaemia in $36 \%$ of the cases [Daschner, 1982; Caplan, 1979], and prolongs ICU-stay [Craig, 1984]. Adequate treatment of lower respiratory tract infection often is not possible, and death may result, especially if Gram-negative bacilli are involved. ICU-acquired lower respiratory tract infection was reported to be associated with an important increase in mortality [Craig, 1984; Craven, 1986; Ruiz-Santana, 1987]. However, a direct relationship between pneumonia and increased mortality could not be established [Craven, 1986]. Although contaminated respiratory equipment has been eliminated as source of lower respiratory tract infection [Pierce, 1970; Comhaire, 1981] the incidence of these infections in patients who are intubated and mechanically ventilated still remains unacceptably high. This review will focus on the pathogenesis of lower respiratory tract infection in mechanically ventilated patients, and on the potential strategies for its prevention. The emphasis will be laid on selective decontamination of the digestive tract.

\section{Etiology}

Respiratory tract infections that occur in the first days of mechanical ventilation often have the same etiology as community-acquired infection [Woodhead, 1987; White, 1981]: they are predominantly caused by Streptococcus pneumoniae, Staphylococcus aureus and Haemophilus influenzae [Ruiz-Santana, 1987; Stoutenbeek, 1987].

Later during ICU-stay Gram-negative bacillary infection is increasingly impor- 
tant, accounting for more than $80 \%$ of the lower respiratory tract infections which occur after more than three days of mechanical ventilation [Stoutenbeek, 1987; Ruiz-Santana, 1987]. Pseudomonas aeruginosa, Klebsiella sp. and Escherichia coli are the most commonly isolated organisms, but other Gram-negative bacilli e.g. Enterobacter sp., Proteus sp. and Serratia sp. also play a role [Daschner, 1982; Sanford, 1986].

\section{Pathogenesis}

Bacteria may reach the lower respiratory tract in three different ways: by haematogenous spread, by inhalation, or by aspiration of oropharyngeal or gastric contents.

Aspiration is the most important way of spread of bacteria to the lower airways in hospital-acquired pneumonia [Laforce, 1981; Podnos, 1985]. Microorganisms colonizing the oropharynx may be introduced to the lower airways by aspiration of oropharyngeal contents at the onset of acute disease [Langer, 1987] or at endotracheal intubation |Nair, 1986]. Later during intensive care stay aspiration of oropharyngeal secretions and gastric contents continues to be the major cause of pneumonia. Aspiration is enhanced by depressed consciousness [Huxley, 1978; Langer, 1987], a condition that is present in a great majority of mechanically ventilated patients, caused either by disease itself or by sedation. Aspiration is further facilitated by the presence of endotracheal or tracheostomy tubes [Cameron, 1973; Spray, 1976]. Small quantities of oropharyngeal secretion may pass the cuff of the endotracheal tube, especially if high volume cuffed tubes are used [Seegobin, 1986; Pavlin, 1975]. In critically ill patients, the concentration of Gram-negative bacilli in the oropharyngeal secretions is usually high and may exceed $10^{7}$ organisms per milliliter [Van Uffelen, 1984]. This means that even aspiration of only $0.001 \mathrm{ml}$ will introduce a bolus containing more than $10^{4}$ organisms into the tracheobronchial tree. Antibacterial defense mechanisms of the lung perform less well when presented with bacteria in a fluid bolus than when bacteria are deposited as a small particle aerosol: in experimental animals, intratracheal instillation of a fluid bolus containing $10^{4}$ microorganisms produced clinical signs of respiratory tract infection, whereas aerosol challenge of $10^{7}$ did not result in clinical illness [Berendt, 1978]. Moreover, pulmonary antibacterial defense mechanisms are known to be compromised by shock, acidosis, pulmonary oedema and hypoxia [Green, 1977] all of which are common in critically ill patients. Under these circumstances aspiration of even a minute quantity of oropharyngeal or gastric contents may give rise to lower respiratory tract infection [Johanson, 1984]. Colonization of the oropharynx and of the stomach with Gram-negative bacilli play a pivotal role in the pathogenesis of these infections. 
In normal persons oropharyngeal colonization with Gram-negative bacilli doesn't occur: only $2 \%$ of healthy individuals harbor Gram-negative bacilli in their oropharynx, and then only transiently [Johanson, 1969]. Inoculation of even large numbers of Gram-negative bacilli into the mouths of healthy subjects does not cause colonization. La Force et al. studied the elimination of Gram-negative bacilli from the oropharynx after gargle challenge: when suspensions of Gramnegative bacilli (Escherichia coli, Klebsiella pneumoniae and Proteus mirabilis) were gargled by normal volunteers, bacterial counts rapidly decreased and less than $1 \%$ of the original inoculum was recoverable after 3 hours. Even piliated $E$.coli (which adhered well to buccal cells in vitro) was rapidly cleared from the oropharynx [La Force, 1976].

This finding suggests the presence of highly effective mechanisms to exclude Gram-negative bacilli from the normal upper respiratory tract. These mechanisms, which prevent colonization of the oropharynx with potentially pathogenic microorganisms, will be referred to as colonization resistance. Several factors contribute to colonization resistance:

(1) mechanical factors,

(2) factors that influence bacterial adherence,

(3) the autochthonous oropharyngeal flora.

(1) Mechanical factors, such as salivary flow and swallowing, rapidly clear about $90 \%$ of the Gram-negative bacilli before they can get attached to oropharyngeal epithelial cells [La Force, 1976]. The approximately $10 \%$ of bacteria that are not immediately cleared from the oropharynx mechanically, normally do not adhere to the oropharyngeal mucosa.

(2) Adherence is influenced by several factors. The most important is fibronectin, a high-molecular weight glycoprotein which covers the oropharyngeal cell surface, and so modulates the oropharyngeal flora. Fibronectin promotes the adherence of certain Gram-positive cocci (e.g. Streptococcus pyogenes) but prevents the colonization with Gram-negative bacilli [Woods, 1981; Abraham, 1983]. Fibronectin is cleared from the cell surface by the excess proteolytic enzyme activity that occurs in the oropharyngeal secretions of severely ill patients [Woods, 1981,A]. The loss of cell surface fibronectin is associated with increased adherence of Gram-negative bacilli to buccal epithelial cells in vitro, and with an increase of the incidence of oropharyngeal colonization in vivo [Woods, 1981; Woods, 1983]. In their study in patients undergoing elective cardiac surgery, Dal Nogare et al recently demonstrated that most of the fibronectin digestive activity is due to elastase derived from polymorphonuclear cells [Dal Nogare, 1987], which are the principal cells in the saliva (other than desquamated squamous cells).

Salivary IgA also exerts inhibitory activity on the adherence of bacteria to the 
mucous membrane [Williams, 1972]. Degradation of IgA by polymorphonuclear cell elastase was described in patients with chronic tracheostoma [Niederman, 1986].

The normal inflammatory response of the respiratory tract to the presence of bacteria may therefore actually enhance Gram-negative bacillary colonization by degradation of both cell surface fibronectin and of IgA.

(3) The autochthonous oropharyngeal flora is another important factor preventing colonization with Gram-negative bacilli.

It has been supposed that aerobic oropharyngeal bacteria, primarily $\alpha$-haemolytic streptococci, protect the oropharynx against Gram-negative bacillary colonization, because suppression of oropharyngeal $\alpha$-haemolytic streptococci with penicillin was associated with colonization with Gram-negative bacilli [Sprunt, 1969], and this colonization did not occur in patients carrying penicillin resistant streptococci in the ir oropharynx [Sprunt, 1971]. However, the inhibiting flora might as well be the anaerobic oropharyngeal flora, which is also influenced by the administration of penicillin. Several anaerobic bacteria isolated from the oropharynx of healthy volunteers, particularly Bacteroides melaninogenicus, have been shown to inhibit the growth of most Gramnegative bacilli in vitro |Murray, 1976]. Like the anaerobic flora of the lower digestive tract (chapter I), the autochthonous anaerobic flora of the orophar$\mathrm{ynx}$ is considered to play an important role in the defense against colonization with Gram-negative bacilli [George, 1982].

Mechanisms by which the autochthonous flora limits colonization by Gramnegative bacilli are not well known but may include: the shielding of mucosal receptors, production of toxic substances such as volatile fatty acids, and competition for food [Clasener, 1987].

Like in the lower digestive tract, the role of the autochthonous flora in the prevention of colonization with Gram-negative bacilli will be referred to as Microbial Colonization Resistance (MCR), whereas the mechanical clearance of bacteria and the factors which prevent bacillary adherence will together be called Physiological Colonization Resistance (PCR). PCR and MCR together normally offer a highly effective protection against colonization of the oropharynx with Gramnegative bacilli.

However, in critically ill patients, Gram-negative bacillary colonization of the oropharynx readily occurs. Johanson et al found that, whereas Gram-negative bacillary colonization of the oropharynx was present only in $2 \%$ of healthy individuals, it occured in $35 \%$ of moderately ill patients an in $73 \%$ of critically ill patients [Johanson, 1969]. This colonization occurred soon after admission and played an important role in the pathogenesis of lower respiratory tract infection. Respiratory tract infection occurred in $23 \%$ of the ICU-patients with oropharyngeal colonization with Gram-negative bacilli but only in $3.3 \%$ of the non-coloni- 
zed patients [Johanson, 1972]. The following clinical factors appeared to be associated with an increased risk of oropharyngeal colonization: coma, hypotension, endotracheal intubation and azotaemia. The use of some antibiotics probably also promoted colonization [Johanson, 1972]. The importance of the association between antibiotic therapy and oropharyngeal Gram-negative bacillary colonization was further emphasized by other authors [Le Frock, 1979, A; Nord, 1984; Rose, 1975]. Other conditions associated with an increased risk of colonization of the upper respiratory tract are diabetes, ethanol abuse [Mackowiak, 1978], advanced age and disability [Valenti, 1978].

Of these conditions intubation and coma, which both are present in virtually all mechanically ventilated patients, are of paramount importance, because these two factors are not only associated with increased risk of colonization but also with an increased risk of pneumonia [Johanson, 1972].

\section{Colonization of the stomach}

The acid environment of the stomach is normally sterile [Wilson, 1983]. However, in critically ill patients colonization of the stomach with potentially pathogenic microorganisms frequently occurs. In his study of ten mechanically ventilated patients, Atherton observed colonization of the stomach with predominantly Gram-negative microorganisms in nine. Tracheal colonization was observed in all ten patients, six of whom carried the same microorganisms in the trachea as in the stomach [Atherton, 1978]. Gastric colonization increases if the gastric $\mathrm{pH}$ is increased by the use of antacids or $\mathrm{H} 2$-blockers. Several authors have correlated high levels of gastric $\mathrm{pH}$ with logarithmic increases in the concentrations of Gramnegative bacilli in gastric aspirates [Hillman, 1982; Du Moulin, 1982; Donowitz, 1986], and have demonstrated the development of retrograde colonization from the stomach to oropharynx and lower airways [Du Moulin, 1982; Daschner, 1988]. Recent studies have shown that the use of sucralfate - a cytoprotective agent that does not effect gastric $\mathrm{pH}$ - results in a lower rate of gastric colonization and of ICU-acquired pneumonia than does the use of antacids or H2-blockers [Driks, 1987; Tryba, 1987; Daschner, 1988]. However, Gram-negative bacillary colonization of the stomach was not entirely prevented and the decrease of the incidence of pneumonia was not significant [Driks, 1987]. Enteral feeding can also play a role in the pathogenesis of gastric colonization, directly by administration of contaminated feeding or indirectly by increasing the $\mathrm{pH}$ [Pringleton, 1986].

\section{Sources of microorganisms colonizing oropharynx and stomach}

Microorganisms colonizing oropharynx or stomach might derive either from the patient's own digestive tract (endogenous) or from other sources (exogenous). 


\section{Endogenous sources}

The most important endogenous source of microorganisms causing colonization and $\triangle \mathrm{CU}$-acquired infection is the patient's own faecal flora.

Le Frock et al observed Gram-negative bacilli other than Escherichia coli ( $K$ lebsiella. Enterobacter and Proteus) as predominant in the faecal flora of $60 \%$ of all hospitalized patients [Le Frock, 1979]. This occurred even in patients who were only moderately ill and did not receive antibiotics. The Gram-negative bacilli which appeared in the oropharyn were nearly al ways the same as those in the faecal flora, pointing to the latter as the origin of newly appearing oropharyngeal strains [Le Frock, 1979, A]. Transmission of faecal microorganisms occurs mostly by faecal-oral contact, either via the hands of the patient, or via the hands of medical personnel [Maki, 1978]. Theoretically, the retrograde spread of microorgan-

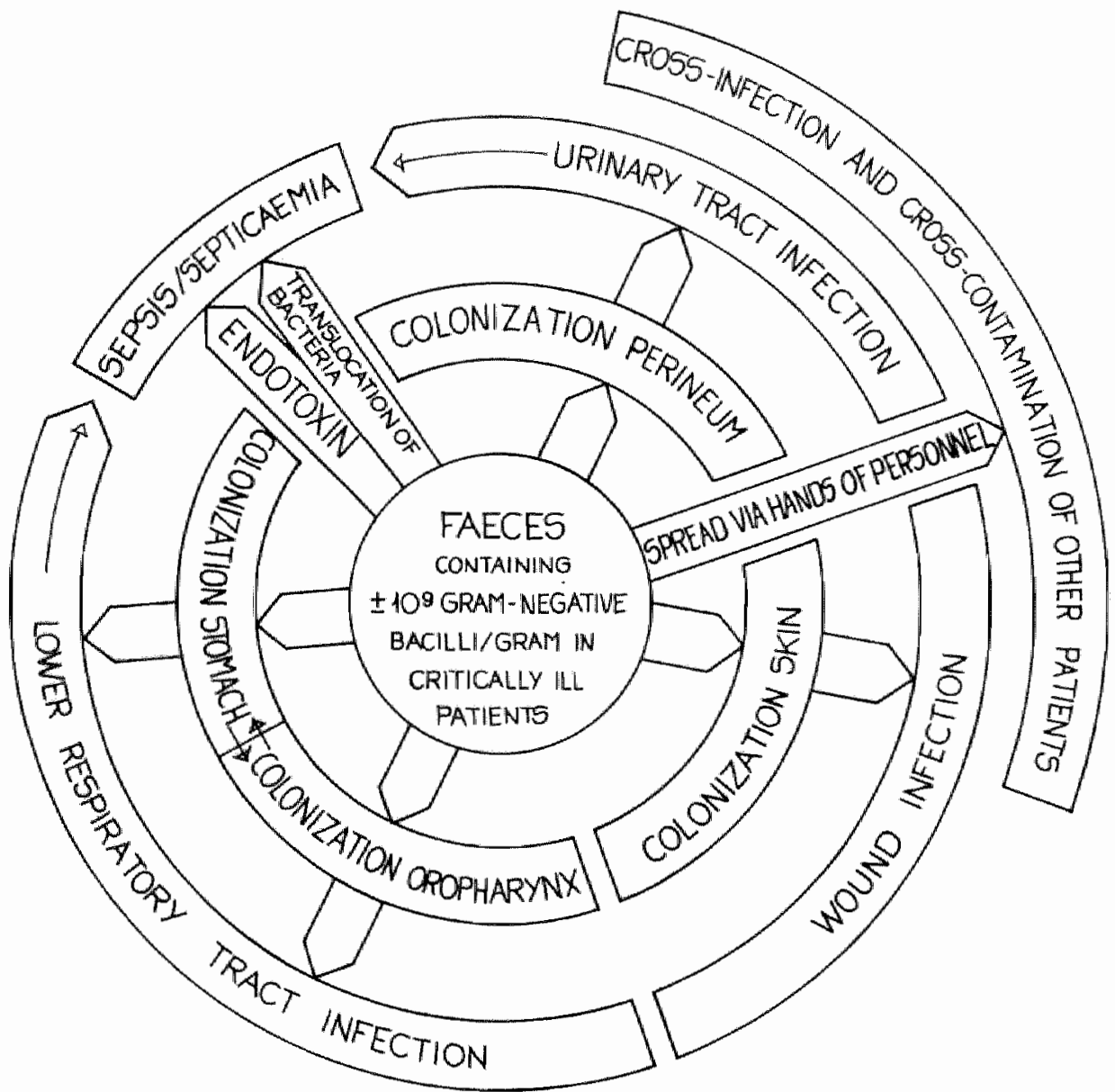

Fig. I The central role of faecal microorganisms in the development of ICUacquired infections. 
isms from the intestines to the stomach is also possible, especially when peristals is is impaired.

The use of antibioties that disturb the autochthonous anaerobic intestinal flora does increase the faecal concentration of Gram-negative bacilli, thereby increasing the risk of contamination and infection from this source (chapter $\rrbracket$ ) $[\mathrm{Clasener,}$ 1987].

Figure I illustrates the central role that faecal microorganisms play in the development of infection in critically ill patients.

\section{Exogenous sources}

Exogenous sources of colonization potentially include every human or inanimate object in the hospital. The most important exogenous source of microorganisms, however, is faecal material, deriving from other patients, as was found by Selden et al in their study of endemic infection with multi-resistant Klebsiella |Selden, 19711. Respiratory secretions or urine from infected patients can also be the source of microorganisms [Penn, 1981]. The most important mode of transmission of microorganisms from patient to patient, is the spread via the hands of personnel. [Maki, 1978; Knittle, 1975; Casewell, 1977].

Microorganisms transmitted from patient to patient may either directly colonize oropharynx or stomach, or may first colonize the patient's own lower digestive tract and subsequently colonize oropharynx and stomach via faecal-oral contamination.

Contaminated respiratory equipment normally does not give rise to microbial colonization of oropharynx or stomach, but to direct introduction of potentially pathogenic microorganisms in the lower respiratory tract [Kerver, 1987].

\section{Prevention}

In the past twenty years much attention has been given to the prevention of ICU. acquired pneumonia caused by contaminated respiratory equipment or by crossinfection. The decontamination of humidifiers and ventilators, and the changing of respiratory tubing every 48 hours have reduced lower respiratory tract infection from these sources to a minimum [Craven, 1987]. Proper hand washing and other hygienic measures [Simmons, 1983] are now well established in most ICU's.

However, despite infection-control measures directed at eliminating reservoirs and interrupting modes of transmission of Gram-negative bacilli, colonization of oropharynx and stomach, with subsequent aspiration and lower respiratory tract infection, still frequently occurs.

Possible further strategies for the prevention of lower respiratory tract infection involve: prevention of aspiration, enhancement of lung defenses and the prophylactic administration of antimicrobial agents.

Aspiration of small quantities of pharyngeal secretion is probably unavoidable in 
seriously ill patients, especially if the patient carries an endotracheal or tracheostomy tube.

Immunization may enhance lung defenses, but not immediately and only for the vaccinated strains [Polk, 1973; Maki, 1978].

The prophylactic use of systemic antibiotics has not been successful in the past: it has been found not to reduce the infection rate, and to cause superinfection with resistant strains [Lepper, 1954; Petersdorf, 1957; Price, 1973], and is, therefore, generally rejected [Caplan, 1979]. Topical application of antibiotics in upper and lower airways was studied by several groups, but did not reduce the respiratory tract infection rate [Feeley, 1975] and resulted in resistance against the antibiotics used [Klastersky, 1974].

\section{Selective decontamination of the digestive tract}

In the early 1970's Van der Waaij et al performed a series of experiments on irradiated mice. In these experiments, that were recently reviewed [Clasener, 1987], it appeared that the most effective prevention of infection in irradiated mice was the oral administration of antibiotics that eliminated the potentially pathogenous aterobic microorganisms (predominantly Gram-negative bacilli) from the digestive tract. The anaerobic intestinal flora, that was demonstrated to have a limiting effect on the growth of potentially pathogenic aerobic microorganisms, was spared [Van der Waaij, 1974]. This technique - elimination of aerobic Gram-negative bacilli from the digestive tract, while sparing the autochthonous anaerobic flora - is called Selective Decontamination of the Digestive tract (SDD) (chapter 1). The value of SDD in the prevention of infection in neutropenic patients has been established in prospective controlled studies [Sleijfer, 1980; Gurwith, 1979; Karp, 19871.

In 1984 SDD was first applied in mechanically ventilated patients. Stoutenbeek et al studied 63 trauma patients who required mechanical ventilation for more than five days [Stoutenbeek, 1984]. The patients received a regime of SDD consisting of polymyxin E (colistin), tobramycin, and amphotericin B (the PTA-regime), administered to the stomach via the nasogastric tube and to the mouth in a sticky paste. They were further given systemic cefotaxime $(50-60 \mathrm{mg} / \mathrm{kg} / \mathrm{d})$. Systemic celotaxime was added to the regime because, in a pilot study, SDD alone did not prevent early lower respiratory tract infection [Stoutenbeek, 1987]. In the group of patients so treated the incidence of lower respiratory tract infection was eight percent. A retrospective control group of 59 patients who had been admitted to the same intensive care unit three years earlier, had a $59 \%$ incidence of respiratory tract infection; a highly significant difference $(\mathrm{p}<0.001)$. The two groups had similar hospital trauma indices. There were five infection-related deaths in the 
control group and none in the treatment group. Several other studies of the use of SDD in mechanically ventilated patients have been published with similar effect on the infection rate [Van Griethuizen, 1987; Van Uffelen, 1987; Kunnen, 1989; Ledingham, 1988]. However, in all studies the infection rates were compared to those in retrospective control groups. Only recently, the results have been published of a prospective randomized study of the effect of SDD in surgical patients requiring prolonged mechanical ventilation [Kerver, 1988]. In the control group $(n=47)$ a restrictive antibiotic policy was followed, whereas patients in the study group $(n=49)$ received the PTA-regime of SDD throughout admission, in combination with systemic cefotaxime prophylaxis $(50-70 \mathrm{mg} / \mathrm{kg} / \mathrm{d})$ during the first five to seven days. Application of this regime reduced the overall incidence of $\mathrm{ICU}$ acquired infection from $81 \%$ in the control group to $39 \%$ in the SDD group $(p<0.001)$. The patients in the control group together acquired 40 lower respiraw tory tract infections, versus six lower respiratory tract infections in the SDD group $(\mathrm{p}<0.001)$. SDD appeared to be especially effective in the prevention of Gramnegative infections and of mixed Gram-positive/Gram-negative infections: The incidence of Gram-positive infections was not significantly reduced.

All but one author [Van Griethuizen, 1987] studying the effect of SDD in mechanically ventilated patients have used the PTA-regime which has been described above, mostly in combination with systemic cefotaxime. Although effective, this regime has two major disadvantages. It is expensive (DFI 65/day to which DFI $\| 15$ has to be added for every day of systemic cefotaxime prophylaxis [Vollaard, 1984]. More important is that the orally administered tobramycin, although poorly resorbed, may give rise to detectable serum levels, which - especially in patients with impaired renal function - might even exceed the level of ototoxicity and nephrotoxicity [Sciarra, 1988].

Further prospective studies are required, both 10 confirm the effectiveness of the concept of SDD in mechanically ventilated patients and to develop safer and less expensive regimes of SDD.

\section{References}

Abraham SN, Beachey EH. Simpsom WA. Adherence of Streptococcus pyogenes. Escherichia coli. and Pseudomonas aeruginosa to fbronectin-coated and uncoxted epithelial cells. Infect Immun $1983: 41: 1261-68$.

Atherton $\mathrm{ST}$, White DJ. Stomach as sounce of bacteria colonizing respiratory tract during artificial ventilation. Lance 1987; ii: $968-9$

Berendt RF. Relationship of method of administration to respirattory virulence of Klebsiclla pneumonia for mice and squirrel monkeys. Intect lmmun 1978; 20:581-3.

Cameron JL. Reynolds J. Zuidema GD. Aspiration in patients with tracheostomies. Surg Gyn Obst 1973: 136: 68-70.

Caplan ES. Hoyt N. Adams Crowley R. Changing patterns of nosocomial infections in severly rramatized patients. Am Surg 1979; 45: 204-10. 
Casewell M. Phithips 1. Hands as route of transmission for Klebsiella species. Br Med J 1977: ii: 131517.

Clasener HAL. Vollatard E, Van Saene HKF. Long-term prophylaxis of infection by selective decontamination in leucoperia and in mechanical ventitation. Rev Infect Dis 1987; 9:295-328.

Combatre A. Lamy M. Contamination rate of sterilized ventilators in an ICU. Crit Care Med 1981:9: $546-8$

Cratg CP. Connelly $\$$. Effect of intensive care nosocomial pneumonia on duration of stay and mortalty, Am J Infect Contr 198: 12:233-8

Crawen DE, Kunches LM. Kilinsky V. Lichtenberg DA. Make BI. McCalbe WR. Risk factors for preumonial and fatality in patients recieving continuous mechatnical ventilation. Am Rev Resp Dis $1986: 133: 792-6$.

Crawen DE. Driks MR. Nosocomial pneumonia in the intubated parient. Seminars in Respirattory Infeetions $1987: 2: 20-33$

Cross AS. Roup B. Role of respiratory assistance devices in endemic nosocomial pneumonia. Am J Med 1981: 70:681-5.

Dal Nogare AR, Toews GB, Pierce AK. Increased sal ivary elatslase precedes Gram-negalive bacillary colonization in postoperative patients. Am Rev Resp Dis 1987: 135:671-5.

Daschner FD, Frey P. Wolff G, Baumann PC. Suter P. Nosocomial infections in intensive care wards: at multicenter prospective study. Intensive Care Med 1982;8:5-9.

Ditschner F. Kappstein I. Engels I. ci al. Stress ulcer prophylatx is and ventiation pneumoniat prevention by antibaterial cytoprotective agents? Infect Control Hesp Epidemion 1988; 9; $59-65$.

Donowit\% LG. Page C. Mileur BL. Guenther SH. Alteration of normal gastric flora in critical care patticnts receiving antacid and eimetidine therapy. Infiect Conur 1986; 7:23-6.

Driks MR. Craven DE, Celli BR. et at. Nosocomial pneumonia in intubated patients given sucrallate ats compared with antadeids or histamine type 2 blockers. N Engl J Med 1987; 317: 1376-82.

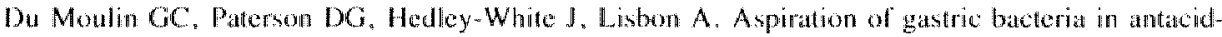
treated paticnts: a frequent cause of postoperative collonization of the a a rway. 1 .ancel 1982; i: 242-5.

Feeley TW, Du Moulin GC. Hedley-Whyte J, Bushnell LS, Gilber JP, Feingold DS. Acrosol polymyxin and pnewmonia in seriously ill palients. N Engl J Med 1975;293:471-5.

George WL. Finegold SM. Bacterial infections of the lung. Chesi 1982: $81: 502-7$

Green GM, Jakab GJ, Low RB, Davis GS. Defense mechanisms of the respiratory membrane. An Rev Resp Dis: 1977; 115:479-514.

Gurwith MJ, Brunton JL, Lank BA, Harding GKM. Ronald AR. A prospective controlled investigattion of prophylactic trimethoprindsullame thoxazolle in hospitalized granulocylopenic patients. Am J Med 1979; 66: 248-56.

Hillman KM, Riordan T, O Farrell SM. Tabangchali S. Colonization of the gastric contents in critically ill patients. Cril Carc Mad 1982: 10:444-7.

Huxley I:J, Viroslay J, Gray WR, Pierce AK. Pharyngeal aspiration in nomal andults and in patients with depressed consiousness. Am I Mad 1978: 64:564-8.

Johanson WG. Picrce AK, Sanford JP. Changing pharyngeal flora of hospitalized patients. N Engl J Mod 1969:281:1137-40

Johanson WG, Pierce AK. Sanford JP. Thomas GD. Nosocomial respiratory infections with Grammegative bacilli: The signilicance of colonization of the respiratory tract. Ann Intern Med 1972:77: $701-6$

Johanson WG. Prevention of respiratory tract infectom. An J Med 1984: 76 (Suppl 5al): 69-77

Karp IE, Mer. WG. Hendricksen C. et al. Orat norlloxacin fer prevention of Gram-negative bacterial infections in patiens with ateute leacaemia and granulocytopenia. Ann Int Med 1987:106: 1-7.

Kerver AJH, Rommes JH, Mevissen-Verhage EAE, et al, Colonization and infection in surgical intensive care patients: a prospective study. Intensive Care Med 1987; 13: 347-51.

Kerver AJH, Rommes JH. Mevissen-Verhage EAE, et al. Prevention of colonization and infection in critically ill patients. Crit Care Mod 1988; 16:1087-93.

Klastersky I. Huysmans E, Weeris D. Hensgens C. Daneau D. Endothracheally administered gentamicin for the prevention of infections of the respiratory tract in patients with tracheostomy: a doubleblind study. Chest 1974:65:650-4. 
Krittle MA. Eitzman DV. Bater H. Role of hand contamination of perwonnel in the eptuenichlogy of Gram-thegarive nosocomial infections. I Paediatr 1975; 86:433-7.

Kunnen HJ, Krikken J. Van Stene HKF. Signiffeant reduction of infection-related murbidity and mortality by proplylactic llora suppression in long stay intensive care uni pattents: it prospective onsecutive study. Crit Care Med. In press.

La Force MD. Hospital-acquired Gram-negative mol phewnonoss: an overview. An $/$ Med 1981; 70; $664-9$.

La Force FM. Hopkins J. Trow R. Wang WLL. Human oral defenses againt Gram-negative rods. Am Rev Respir Dis 1976; 114:929-35.

Langer M. Cigada M. Mandelli M. Mosconi P. Tognoni G. Earty onset preumonia a malticenter study in intensive care units. Intensive Care Med 1987: 13: 342-6.

Le Frock JL, Ellis CA, Weinstein L. The relation between aerobic fecal and oropharyngeal microfhorit in hospitalized pattients. Am J Med Sci 1979A: 277: 275-280.

Le Frock $\mathrm{IL}$. Ellis CA, Weinstein L. The impact of hospitalization on the aerobic microflora. An J Med Science 1979:277: 269-74.

Ledingham IMCA. Alcoek SR, Eatstaway AT. McDonald JC, McKay IC, Ramsily G. Triple reginen of selective decontamination of the digestive tract, systemic cefolaxime, and microbiological surveitlance for prevention of acquired infection in intensive care. Lancet 1988: i: 785-90.

Lepper MH, Kofman S. Biatt N, Dowling HF, Jackson GG. Effect of eight antibiotics used singly and in combination on the tracheal flora following tracheotomy in pollonnyclitis. Antibiotics Chemother $1954 ; 6: 829-43$

Mackowiak PA, Martin RM. Jones SR, Smith JW. Pharyngeal colonizathon by Giam-negative bacilli in aspiration-prone persions. Areh Intern Med 1978; 138: $1224-7$.

Maki, DG. Controt of colonization and transmission of pathogenic bacteria in the hospital. Am Int Med 1978: 89 (part 2): $777-80$.

Murray PR, Rosenblat JE. Bacterial interference by orophatryngeal and clinical isolates of anterobic bincteria J Inleet Dis 1976:134:281-5.

Nair P. Jani K. Sanderson PJ. Transfer of bacieria into the trachea during endotracheal intubation. J Hosp Infeci 1986; 8: 96-103.

Niederman MS. Merrill WW, Polomski LM. Reynolds HY, Gee JBL. Intlenence of sputum IgA and clastase on tracheal ocll bacterial adherence. Am Rew Respir Dis 1986; 133: 255-60.

Nerd CE, Kager L. Heimdath A. Impact of antimicrobiol agents on the gastronintestinall microflerta and the risk of intections. Am J Med 1984: 76 (Suppl 5a): 99-106.

Pawlin EG. Var Nimwegan D. Hornbein TF. Failure of a high-compliance low-pressure culf to prevent aspiration. Anesthesiology 1975:42:216-4.

Penn RG. Sinders WE. Sanders CC. Colonization of the oropharynx with Gram- negative bacilli: A major antecedent to nosocomial pnetumonia. Am I Infeet Cont 1981:9:25 34.

Petersdorf RG. Curtin JA. Hoeprich PD. Pecter RN. Bennetl 1L. A study of antibiotic propliylaxis in unconscious pationts. N Engl J Mod 1957: 257: 1002-4)

Pierce AK. Sunford JP. Thomas GD. Leonard JS. Long-term cvaluation of docontamirsation of inhat atthon-therapy equipment and the occurrence of necrotinge pneumonia. N Lingl $\mathbb{I}$ Med 1970.282: $528-31$

Podnos SD. Toews GB, Picre AK. Nosocomial poemonta in patients in intensive ware units. West J Mcd 1985: 143:622-7

Polk HC. Berden S. Adirete JA. Prevention of Pseatlomonats respiratory infection in a surgiatl intensive care unit. Ann Surg 1973:177:607-13.

Price DJ. Sleigh JD. Control of infection due te Klobsictlat atogenes in a neurasurgical unit by withdrawal of all antibiotics. Lance 1970; it: 1213-5.

Pringleton SK. Hinthorn DR. Liu C. Enteral nutrition in palients receiving mechanteal venilation: mulliple sources of tratheal colonization include the stomath. Am J Med 1986; 80: 827-32.

Rose HD. Babcock JB. Colonization of intensive catre unit patients with Gran-negative bacilli. Am $₫$ Epidem 1975: 101: 495-501.

Ruiz-Santana S. Jimenez AG, Esteban A. et al. HCU pneumonias: a multi-insitutional study. Crii Care Med 1987: 15:930.2. 
Sanford IP. Lower respiratory tract infections. In Bennet JV, Brachman PS, Eds. Hospitall infections Boston: Little. Brown and company, 1986: 385-422

Sciarra $M$, Cavatiere F, Crociani E, Ciuni $C$. Proietti R. Tobranycin serum levels during selective decontamination of the digestive iract [Abstract). Intensive Care Med 1988; 14 (suppl 1):311.

Secgobin RD, Van Hasselt Gl. Aspiration beyond endotracheal cuffs. Can Anaesth Soe J 1986:33. 273.9 .

Selden R, Lee $S$. Wang WLL, Bennet JV, Eickhoft TC. Mosocomial Klebsiella infections: intestinal colonization as a reservoir. Ann Int Med 1971: 74: 657-64.

Simmons BP, Wong ES. Guideline for the prevention of nosocomial pnew monia. Infect Contr 1983 ; 11: 2309 .

Sleijfer DT, Mulder NH, De Vries-Hospers $H G$, el al. Infection prevention in granulocytopenic patients by selective decentamination of the digestive tract. Europ J Cancer 1980; 16: 859-69.

Spray SB. Zuidema GD, Cameron JL. Aspiration pneumonia; incidence of aspiration with endotracheal uubes. Am J Surg 1976; 131: 701-3.

Sprunt K. Redman W. Evidence suggesting importance of role of interbacterial inhibition in mainlaining balance of normal flora. Ann Intern Med 1968; 68: 579-90.

Sprunt K, Leidy GA, Redman W. Prevention of bacterial overgrowth. J Infeci Dis 1971; 123: 1-10.

Stoutenbeek Chp, Van Saene HKF, Miranda DR, Zandstrat DF. The effect of selective deconamination of the digestive tract on colonization and infection rate in multiple trauma patients. Intensive Carc Med 1984: 10:185-192.

Stoutenbeek ChP, Vam Saene HKF, Miranda DR, Zandstra DF, Langrehr D, The effect of oropharyngeal decontamination using lopical nonabsorbable antibiotics on the incidence of nosocomial respiratory tract infections in multiple tratuma patients. J. Trauma 1987; 27:357-64.

Tryba $M$. Risk of acute stress bleeding and nosocomial pneumonia in ventilated intensive care units patients: sucrall fate versus antacids. Am J med 1987; 83 (suppl 3B) : $117-24$

Valenti WM. Trudell RG, Bentley DW. Factors predisposing to oropharyngeal colonization with Grann-negative bacilli in the aged. N Engl J Mexl 1978; 298: 1108-11.

Van der Waij D. Berghuis-De Vries JM. Selective elimination of Enterobacteriacea species from the digestive tract in mice and monkeys. J Hyg Camb 1974: 72: 205-11.

Van Griethuysen AJA. Clasener HAL, Vollatard EJ, Niessen M. Colonization resistance: a guide to antibiotic pollicy in the ICU. Infect Control 1987;8:269-70.

Van Uffelen R, Van Saene HKF, Fidler V. Löwenberg A. Oropharyngeal flora as at sotrce of bacterial colonizing the lower atrways in patients on artificial ventilation. Intensive Care Med 1984: 10: 233-7.

Van Ufrelen R, Rommes JH, Van Satene HKF. Preventing lower airway colonization and infection in meehanically wentilated patients. Crit Care Med 1987: 15:90-102.

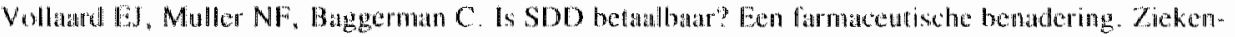
huishygiênc en Infektieprevertic 1984; 3:41-2.

White RJ, Blainey A, Harrison KJ, Clarke SKR. Causes of pneumonia presenting to a district general hospital. Thorax 1581: 36: $5666 \times 70$.

Williams RC, Gibbons RJ. Inbibition of bacterial atherenes by secretory immungglobulin A: A mechanism of antigen disposid. Sci 1972;177: 697-9

Wilson GS. Miles AA, Patker MT. Topley and Wilson"s principles of bacteriology, virology and immunity. Vol I Generall microbiology and immunity. 7th cd. London: Edward Arnold L.td, 1983: $230-44$.

Woodhend MA. Machartane JT, MoCracken JS. Rose DH. Finch RG. Prospective study of the aetiology and outcome of preamonia in the community. Lancet 1987;i: 671-4.

Wouds DE, Stratus DC. Johanson WG. Bass JA. Role of salivary protease activity in adherence of Gram-negative bacilli to mammalian buceall epitheliatl cells in viva. J Clin lnvest 1981 A, 68: 1435 40.

Woods DE. Straus DC, Johannson WG. Bass JA. Role of fibronectin in the prevention of adtherence of Psedudomonas acruginosit to buccal cells. IInfect Dis 1981:143: 784-90.

Woods DE. Stras DC. Johanson WG. Bass JA. Factors influencing the adtherence of Pseudomonats acruginosia to mammalian buccal epithelial cells. Rex Inteet Dis 1983; 5(Suppl 5): 846-51. 


\section{Selective decontamination and short-term systemic antibiotic prophylaxis in mechanically ventilated patients: study design.}

\section{Aims of the study}

The major aim was to assess, in a prospective, controlled randomized study, the effect of a new regime of selective decontamination and systemic antibiotic prophylaxis in patients requiring prolonged mechanical ventilation. We studied the influence of this regime on the colonization of oropharyin, stomach and rectum with potentially pathogenic microorganisms and on the incidence of lower respiratory tract infection in these patients.

In the first control group we followed conventional antibiotic use, i.e. administration of antibiotics only in case of infection. In this control group we adhered to the antibiotic policy previously used in our unit which involved the use of antibiotics known to disturb the autochthonous anaerobic flora and thus disturbing MCR. The use of these antibiotics might influence the colonization and infection rate (chapter 1). This necessitated the institution of a second control group, in which, like in the first control group, we followed conventional antibiotic use, but in which infections were treated only with antibiotics that do not affect MCR. This permitted us to compare the influence of antibiotics disturbing and those not disturbing MCR on the colonization and infection rate.

The role of oropharyngeal and gastric colonization in the pathogenesis of lower respiratory tract infection was also subject ol study.

\section{Study design}

\section{Study population}

All patients admitted to the JCU of the Nijmegen University Hospilal from May 1986 to September 1987 were eligible for the study. The criterion for inclusion was the expected need for mechanical ventilation for at least five days, regardless of the disease necessitating mechanical ventilation. All patients were included within 24 hours after admission. 
Exclusion criteriat were: age less than 16 years, pregnancy, and allergy to one of the antibiotics used for selective decontamination or to cefotaxime.

Informed consent was obtained from patients or their relatives. The study protocol was approved of by the hospital's institutional review board for human studies.

\section{Randomization}

As soon as possible after admission, the severity of acute illness was assessed using the APACHE II score [Knaus, 1985]. Using this score each patient was entered into one of four categories: APACHE II score less than 10, 10-19, 20-29 and 30 or more. Within these strata, patients were randomly allocated to one of the treatment groups by means of the permuted block method.

\section{Treatment groups (Table I)}

In control Group 1, the patients did not receive any antibiotic prophylaxis. Antibiotic treatment was instituted only on clinical evidence of infection, in which case antibiotics known to disturb MCR were used (see Table I\&II, chapter I).

Table I Studydesign

\begin{tabular}{|c|c|c|c|}
\hline & Group I & Group II & Group III \\
\hline $\begin{array}{l}\text { Antibiotic } \\
\text { therapy }\end{array}$ & $\begin{array}{l}\text { antibioties } \\
\text { affecting MCR }\end{array}$ & \multicolumn{2}{|c|}{$\begin{array}{l}\text { only antibiotics without influence } \\
\text { on Microbial Colonization Resistance (MCR) }\end{array}$} \\
\hline Prophylaxis & \multicolumn{2}{|c|}{ no antibiotic prophylaxis } & $\begin{array}{l}\text { Selective decon- } \\
\text { tamination and } \\
\text { short-term systemic } \\
\text { cefotaxime }\end{array}$ \\
\hline
\end{tabular}

Table II Treatment of infections of unknown etiology (i.v.)

\begin{tabular}{lll} 
& Group I & Group II and III \\
\hline $\begin{array}{l}\text { ampiobic } \\
\text { infection }\end{array}$ & $\begin{array}{l}\text { (or piperacillin I g qid) } \\
\text { in combination with } \\
\text { gentamicin } 80 \mathrm{mg} \text { tid }\end{array}$ & $\begin{array}{l}\text { cefotaxime I g qid } \\
\text { (or cefuroxime } 750 \mathrm{mg} \text { tid) } \\
\text { in combination with } \\
\text { gentamicin } 80 \mathrm{mg} \text { tid }\end{array}$ \\
\hline $\begin{array}{l}\text { anacrobic } \\
\text { infection }\end{array}$ & metronidazole $500 \mathrm{mg}$ tid \\
\hline
\end{tabular}

Dosages are for adults of $70 \mathrm{~kg}$. 
Infection of unknown etiology was treated with intravenous therapy with ampicillin $1 \mathrm{~g}$ qid (or piperacillin $1 \mathrm{~g}$ qid) in combination with gentamicin $80 \mathrm{mg}$ tid (Table II).

In control Group II, the patients received, like in the other control group, antibiotic treatment only on clinical evidence of infection. However, if antibiotic therapy was necessary, only antibiotics without influence on MCR were used (see Table I\&II, chapter I). Infection of unknown etiology was treated with intravenous therapy with cefotaxime $1 \mathrm{~g}$ qid (or cefuroxime $750 \mathrm{mg}$ tid) in combination with gentamicin $80 \mathrm{mg}$ tid (Table II)

In Group III: the patients started with SDD and systemic antibiotic prophylaxis immediately after randomization. SDD was continued until extubation, systemic prophylaxis was administered only during the first five dlays of admission. When infection occurred it was treated, like in group II, with antibiotics without influence on MCR.

Patients in all three treatment groups occasionally received short-term perioperative systemic antibiotic prophylaxis, but only with antibiotics consistent with the trial protocol.

\section{Selective decontamination and systemic prophylaxis (group /II)}

Selective decontamination: polymyxin $\mathrm{E}$ (colistin) $200 \mathrm{mg}$, norfloxacin $50 \mathrm{mg}$ and amphotericin B $500 \mathrm{mg}$, were administered four times daily via the nasogastric tube to decontaminate the stomach and the lower digestive tract. When gastric suction had to be applied, this was discontinued for I hour after administration of the antimicrobial agents. A sticky paste containing the same agents (polymyxin $\mathrm{E}$ $2 \%$, norfloxacin $2 \%$ and amphotericin B $2 \%$ in hydroxypropylmethylcellulose $4,000 \mathrm{cP} 20 \%$ in white petrolatum) was used to decontaminate the oropharynx. One gram of this paste was applied to the oral mucosa four times daily with a gloved finger or a cotton swab.

Systemic prophylaxis consisted of cefotaxime $500 \mathrm{mg}$ intravenously three times daily, during the first five days of mechanical ventilation.

\section{Justification of the regime used}

\section{Selective decontamination of the digestive tract}

Norfloxacin was the main constituent of our regime of SDD. This quinolone is active against most Gram-negative bacilli, but has only slight activity against anaerobic microorganisms |Wolfson, 1985). Emergence of resistance to norfloxacin is not common [Wolfson, 1985]. Norfloxacin is absorbed incompletely from the digestive tract and therefore reaches high faecal concentrations: at an oral dose 
of $200 \mathrm{mg}$ daily, we measured a norfloxacin concentration of $100 \mu \mathrm{g}$ per gram faeces (unpublished observations). This exceeds the MIC 90 of even the least susceptible strains of Gram-negative bacilli [Wolfson, 1988], but does not affect most of the anaerobic microorganisms in the concentrations in which they are present in the digestive tract [Goldstein, 1987]. This makes norfloxacin very suitable for SDD. Norfloxacin, administered orally in a daily dose of $200 \mathrm{mg}$, eliminated all Gram-negative bacilli from the intestinal tract of healthy volunteers, without signs of disturbed MCR [De Vries-Hospers, 1985]. The effectiveness of SDD with norfloxacin has been proved in three randomized studies in neutropenic patients [Winston, 1986] [Karp, 1987] [Winston, 1987].

To reduce the risk of colonization with Gram-negative bacilli less susceptible to norfloxacin, (e.g. Pseudomonas sp. other than Pseudomonas aeruginosa and Acinetobacter sp.), polymyxin $\mathrm{E}$ was added to the regime. Moreover, the use of a combination of agents decreases the risk of the development of resistance to the agents used for SDD. Amphotericin B was used to prevent colonization with yeasts.

\section{The use of systemic cefotaxime}

In a pilot study, SDD alone did not reduce the incidence of those lower respiratory tract infections which develop during the first days of mechanical ventilation [Stoutenbeek, 1987]. This failure is explained by the fact that, on admission, oropharyngeal microorganisms often have already gained access to the lower airways (chapter II), and cannot be reached by antibiotics that are administered to the upper respiratory tract.

Furthermore, the antibiotics used for SDD are directed mainly against Gram-negative bacilli, and not against the Gram-positive cocci that play an important role in early lower respiratory tract infection. This necessitates the administration of a systemic antibiotic during the first days of mechanical ventilation. Cefotaxime is a suitable agent for this purpose because it is active against the commensal oropharyngeal flora, as well as against most Gram-negative bacilli. Cefotaxime (50-100 $\mathrm{mg} / \mathrm{kg} /$ day intravenously) has now been used for this purpose for more than three years, with good clinical results, and without emergence of resistance [Stoutenbeek, 1987, AJ. However, the dose of cefotaxime that was used seems rather high. At lower doses of cefotaxime, serum and sputum levels still exceed the minimum inhibitory concentrations for Haemophilus influenzae, Streptococcus pneumoniae and most Gram-negative bacilli [Carmine, 1983]. This, and the synergistic activity of cefotaxime and its metabolite desacetyl-cefotaxime against Staphylococcus aureus and most other susceptible microorganisms [Chin, 1984], justifies a lowering of the cefotaxime dose to $500 \mathrm{mg}$ tid. Clinical results of the treatment of lower respiratory tract infection with this dose of cefotaxime have been very satisfactory [Perkins, 1982] [Simon, 1988]. 


\section{Bacteriology}

To monitor colonization at these sites, cultures of gastric aspirate and of oropharyngeal and rectal swabs were performed at admission and thereafter twice weekly. Aspirate of the gastric contents was obtained by suction to the nasogastric tube. The first $10 \mathrm{ml}$ of gastric aspirate were discarded, the second $10 \mathrm{ml}$ (obtained with a new syringe) were cultured.

Cultures of the rectum were obtained by sampling at about $5 \mathrm{~cm}$ proximal from the anus, with a sterile cotton swab moistened with sterile saline.

The oropharynx was sampled with a dry cotton swab.

Cultures of the tracheal aspirate were performed on admission, and thereafter thrice weekly, the tracheal aspirate was collected by suctioning material directly from the lower respiratory tract via the endotracheal tube.

Urinary cultures were performed on admission and thereafter once weekly. All patients in our ward had indwelling urinary catheters, from which the urine was obtained by aseptic punction with a sterile syringe.

Cultures from other sites (blood cultures, cultures from wounds, drains etc.) were taken as clinically indicated.

All samples were immediately plated on the following media: Eosin methyleneblue lactose sucrose agar (Merck, D6100 Darmstadt, F.R.Germany), 7\% sheep blood in blood agar base special (Mast Lab. Ltd.,Boothe, England) and Sabouraud dextrose agar (Difco Lab., Detroit, Mich, , US) with chloramphenicol 40 $\mathrm{mg} / \mathrm{L}$. The oropharyngeal swab and the tracheal aspirate were also plated on Haemophilus selective agar base (Merck) with bacitracine $10 \mathrm{U} / \mathrm{ml}$.

Sabouraud plates were incubated at $29^{\circ} \mathrm{C}$ for seven days. All other plates were examined after overnight incubation at $37^{\circ} \mathrm{C}$ in $7 \% \mathrm{CO}_{2}$.

The tracheal aspirate and oropharyngeal and rectal swabs were inoculated using the four quadrant method. Semiquantitative estimation of the bacterial concentration was made on a scale of 0 to +4 according to the density of growth on the agar plates. Growth in only the first quadrant was reported as +1 , in the second quadrant as +2 , etc.

Serial $1 / 10$ dilutions of the gastric aspirate were made in Thioglycolate medium. One- $\mu \mathrm{L}$ volumes of each dilution were inoculated on the solid media. The solid media were also inoculated with $100 \mu \mathrm{L}$ of the first $1 / 10$ dilution of gastric aspirate, lowering the limit of detection to $100 \mathrm{microorganisms} / \mathrm{ml}$ of gastric aspirate. Concentrations were expressed as the logarithms to the base of 10 of the counts per $\mathrm{ml}$ of gastric aspirate, rounded down to whole numbers (Fig. 1).

Microorganisms isolated were identified and antibiotic sensitivity profiles were determined by standard methods.

\section{Colonization}

Colonization was defined as the presence of the same microorganism in two or 


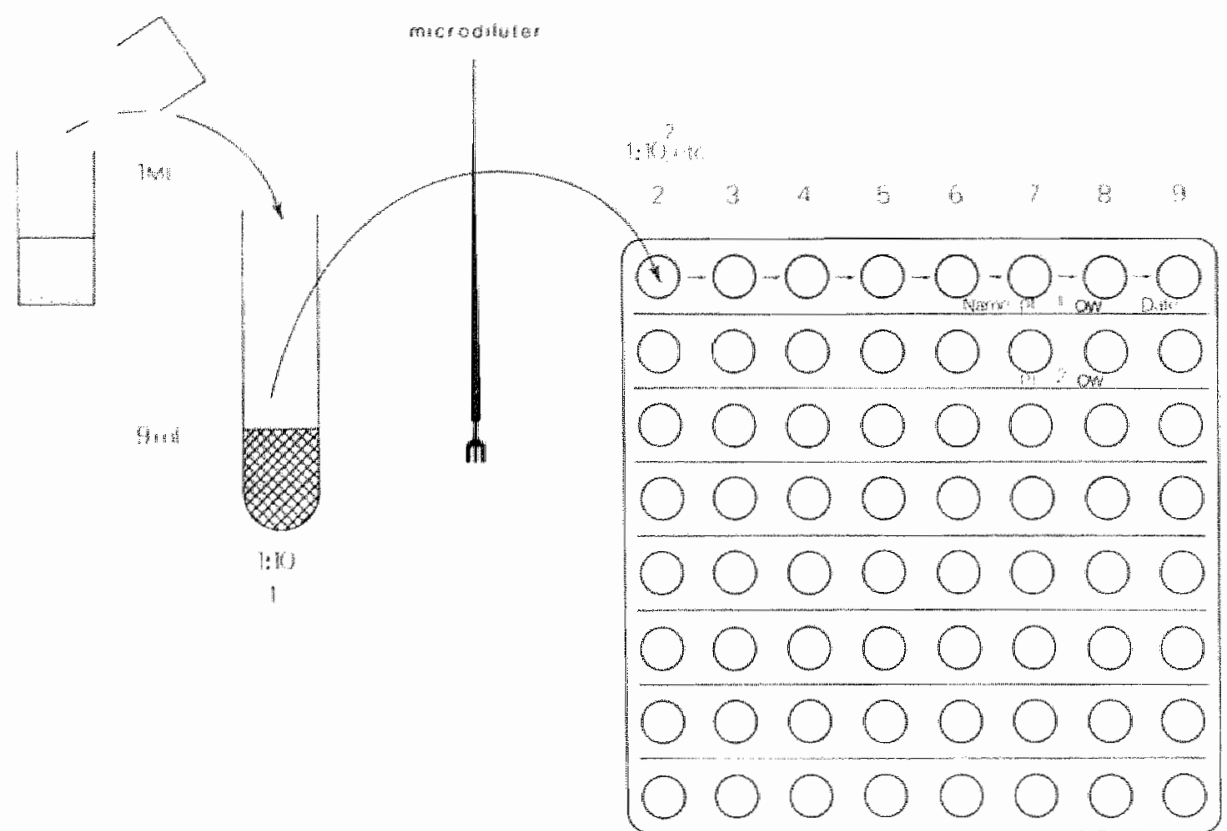

Figure 1 Quantitative tenfold serial dilution method of gastric aspirate (reproduced with permission from: F.K.L. Spijkervet. Irradiation mucositis and oral flora [Dissertation]. Groningen, 1989).

more consecutive samples from the same site, without clinical signs of infection. Microorganisms isolated from samples obtained during the first 24 hours after admission were considered to have been present on admission. Colonization that first occurred afterwards was considered acquired.

To establish the possible influence of the different antibiotic policies in both control groups on the intensity of colonization, we compared the concentrations of Gram-negative bacilli in oropharynx and stomach in patients in groups I and II before and after the start of the first course of antibiotic therapy. The concentrations of Gram-negative bacilli in oropharynx and stomach were determined immediately before the institution of antibiotic therapy, and further between one and four days and between five and eight days after the institution of antibiotic therapy. Patients that had received antibiotic therapy before admission on our ICU were excluded from this part of the study.

\section{Infection criteria}

All infections that were not present on admission, but developed afterwards, were considered intensive care acquired. 
Lower respiratory tract infection was diagnosed if the following three bacteriological criteria were met: (1) positive culture of the tracheal aspirate, (2) Gram stain showing many polymorphonuclear leucocytes as well as (3) the causative organism. This in combination with at least two of the three following clinical findings: (1) purulent aspect of the tracheal aspirate, (2) peripheral leucocytosis of more than 12.000 cells per cubic millimeter, and (3) fever (rectal temperature above $38.0^{\circ} \mathrm{C}$ ). The last two criteria were considered to be signs of lower respiratory tract infection only if they could not be explained otherwise. The diagnosis of a respiratory tract infection was made by a chest-physician (J.Festen) who had no knowledge of the patient's treatment group.

The term lower respiratory tract infection denotes pneumonia or purulent tracheobronchitis. Pneumonia was diagnosed if the criteria mentioned above were met, and the chest roentgenogram (judged by an independent chest-physician) showed a new infiltrate. The emergence of lower respiratory tract infection without these radiographic findings was defined as purulent tracheobronchitis [Unertl, 1987].

A lower respiratory tract infection was called endogenous if it was preceded by colonization of the oropharynx, the stomach or both with the causative microorganism. All other lower respiratory tract infections were considered exogenous.

Urinary tract infection was defined as the presence of $\geq 10^{5}$ colony forming units per $\mathrm{ml}$ of urine. All patients had indwelling catheters.

Septicaemia was diagnosed if one blood culture was positive (in the case of Staphylococcus epidermidis if at least two blood cultures yielded the same strain) in combination with fever (rectal temperature $>39^{\circ} \mathrm{C}$ ), or hypothermia (temperature $\left.<36^{\circ} \mathrm{C}\right)$.

The diagnosis of wound infection was based on purulent discharge from a wound in combination with signs of inflammation and a positive culture.

\section{Institution of antibiotic treatment}

The decision to start antibiotic treatment was not taken by the investigators but by the responsible physicians in the ICU. The infection criteria used by the responsible physician were not necessarily the same as those mentioned above. However, antibiotic treatment was determined by clinical evidence of infection together with microbial findings, and was not based on the results of surveillance cultures.

\section{Statistical analywis}

The data were analyzed with the chi-squared test, or Fisher's exact test for categorical data, or the test of Kruskal-Wallis, Wilcoxon's sum test and Wilcoxon's signed rank test otherwise. A p-value of 0.05 or less was considered statistically significant. 
In the planning stage, it was assumed that the incidence of lower respiratory tract infection in group III would probably be about wen percent, whereas in the other groups this incidence could well exceed $50 \%$.

This assumption was based on the results of a similar study [Stoutenbeek, 1984]. This means that, with a type I error of 0.05 and a type II error of $0.10,20$ patients per group would be needed.

Note: in the context of this document, "there was a difference" implies a significant difference, unless stated otherwise. P-values and $95 \%$ confidence intervals that are not mentioned in the text are available from the author.

\section{References}

Carmine AA, Brogden RN, Heel RC, Speigth TM, Avery GS. Cefotaxime: a rewiew of its antibacterial activity, pharmacological properties and therapeutic use. Drugs 1983; 25:223-89.

Chin N, Neu HC. Cefotaxime and desacetylceforaxime: an example of advantageous antimicrobial metabolism. Diagn Microbiol Inleet Dis $1984 ; 2: 21 \mathrm{~S}-31 \mathrm{~S}$.

De Vries-Hospers HG, Welling GW, Van der Waaij D. Norfloxacin for selective decontarnination: a study in human volunteers. In: Wostmann BS, ed. Germfree research; microflora control and its application to the biomedical sciences. New York: Alan R. Liss, 1985: 259-62.

Goldstein EJC, Citron DM, Corrado ML. Effect of inoculum size on in witro activity of norfloxacin against fecal anacrobic bacteria. Rationale for selective decontamination of the digestive tract. Am J Med 1987; 82(suppl 6B): 84-7

Karp JE, Merz WG, Hendricksen C, et at, Oral norfloxacin for prevention of Gram-negative bacterial infections in patients with acute letcaemia and granulocylopenia. Ann Int Med 1987; 106:1-7.

Knaus WA, Draper EA, Wagner DP, Zimmerman JE. Apache II: A severity of disease classification system. Crit Care Med 1985; 13:818-29.

Perkins RL. Clinical trials of cefotaxime for the treatment of bacterial infections of the lower respira-

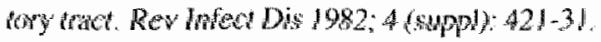

Simon A. Aumont d'Aubrac C. Sufran C. Carbon C. Cefotaxime optimal dosage in adult patients, a reappraisial. Drugs 1988:35(suppl 2):221-30.

Stoutenbeek ChP, Van Saene HKF, Miranda DR, Zandstra DF. The effect of selective decontamination of the digestive tract on colonization and infection rate in multiple trama patients. Intensive Care Med 1984: 10:185-92.

Stoutenbeek ChP, Van Saene HKF, Miranda DR, Zandstra DF, Langrehr D. The effect of oropharyngeal decontamination using topical nonabsorbable antibiotics on the incidence of nosocomial respiratory tract infections in multiple tratema patients. J Trauma 1987; 27:357-64.

Stoutenbeck CP, Van Saene HKF, Zandstra DF. The effect of nonabsorbable antibiotics on the emergence of resistant bacteria in patients in an intensive unit. I Antimicrob Chemother $1987 \mathrm{~A} ; 19$ : 513-20.

Unertl K, Ruckdeschel G. Selbmann HK, et al. Prevention of colonization and respiratory infections in long-term ventilated patients by local antimicrobial prophylaxis. Intensive Care Med 1987; 13 : $106-13$.

Winston DJ, Ho WG, Nakao SL., Gale RP, Champlin RE. Norfloxacin versus vancomycin/polymyxin for prevention of infections in granulocytopenic patients. Am J Med 1986: 80: 884-90.

Winston DJ, Ho WG , Champlin RE, et al. Norfloxacin for the prevention of bacterial infections in granulocytopenic patients. Am J Med 1987; 82(Suppl 6B): 40.6. 
Wolfson JS, Hooper DC. The fuoroquinolones: Structures, mechamisms of action and resistance, and spectra of activity in vitro. Antimicrob Agents Chemother 1985;28:581-6.

Wolfson IS. Hooper DC. Norfloxacin: a new targeted fluoroquinolone antimicrobial agent. Ann Int Med 1988; 108:238-51. 



\section{Selective decontamination and short-term systemic antibiotic prophylaxis in mechanically ventilated patients: results of the colonization study.}

\section{Results of the colonization study}

\section{Study population}

Eighty-eight patients who were expected to require mechanical ventilation for at least five days were randomized on admission (Table I). Twenty-four patients (11 in group I, five in group II and eight in group III) were excluded from the study because mechanical ventilation was discontinued before the 5 th day: sixteen patients improved, and eight patients died before that day (none of these early deaths were caused by infectious disease). Eight additional patients were withdrawn from the study: five ( four in group II and one in group III) because of the necessity to use antibiotics not in accordance with the treatment group, two

\section{Table I Study population}

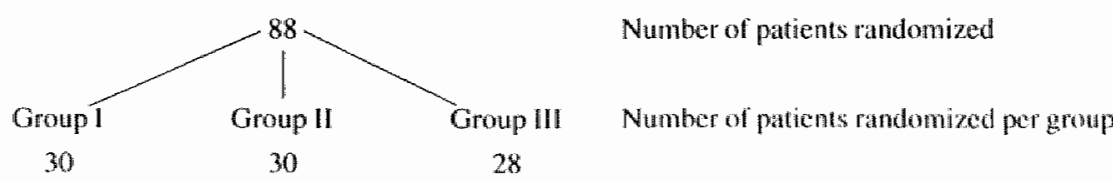

4

Number of patients who died before the Sth day of mechanical ventilation

Number of patients cxtubated before the Sth day of mechanical ventilation

। 
patients (group I and group III) because, although randomized, they were mistakenly not enrolled in the study protocol, and one (group III) because the trial medication had to be discontinued because of severe nausea.

The remaining 56 patients (18 in Group I, 21 in Group II and 17 in Group III) completed the study. The three groups were comparable with respect to age, sex, duration of intubation, duration of intensive care stay, and APACHE II score (Table II). Some important elements of the APACHE II score (temperature, mean arterial pressure, heart rate, respiratory rate, oxygenation score and chronic health points) were separately screened for differences between the groups. No differences were found.

The control and test groups were comparable in terms of diagnostic category on admission (Table III) and incidence of infection on admission (Table IV).

\section{Table II Patient characteristics}

\begin{tabular}{lccc} 
& $\begin{array}{l}\text { Group I } \\
(\mathrm{n}=18)\end{array}$ & $\begin{array}{l}\text { Group II } \\
(\mathrm{n}=21)\end{array}$ & $\begin{array}{l}\text { Group III } \\
(\mathrm{n}=17)\end{array}$ \\
\hline $\begin{array}{l}\text { Age (years) } \\
\text { Sex (m/l) }\end{array}$ & $49 \pm 22$ & $46 \pm 21$ & $45 \pm 24$ \\
ICU-stay (days) & $11 / 7$ & $15 / 6$ & $12 / 5$ \\
Intubation (days) & $30 \pm 17$ & $25 \pm 11$ & $23 \pm 13$ \\
Number of death & $25 \pm 23$ & $22 \pm 16$ & $16 \pm 16$ \\
APACHE II score & 4 & 2 & 2 \\
\hline
\end{tabular}

Figures are expressed in numbers or in means ts standard deviation.

* Not normully distributed and therefore given as the median duration the inter-quartile range.

Table III Diagnostic calegories on ICU-admission

Group 1 Group II Group III

Multiple trauma.

(including heal trauma)

Other meurologic disease

Respintory insufficiency

Cardiovascular surgery

Septicaemia

Miscellaneous

Group 1

Mroup 1

Group [II

Totals 


$\begin{array}{lll}\text { Group I } & \text { Group II } & \text { Group III } \\ (n=18) & (n=21) & (n=17)\end{array}$

Lower respiratory tract

Septicaemia

1

Peritonitis

Urinary tract infection

Other sites

Number infected on admission

6

$9^{*}$

3

0

I

1

0

4

* Im Group II and Group III some patients were admitted with infection at more than one site.

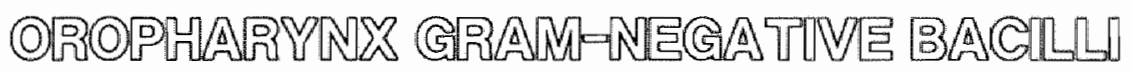

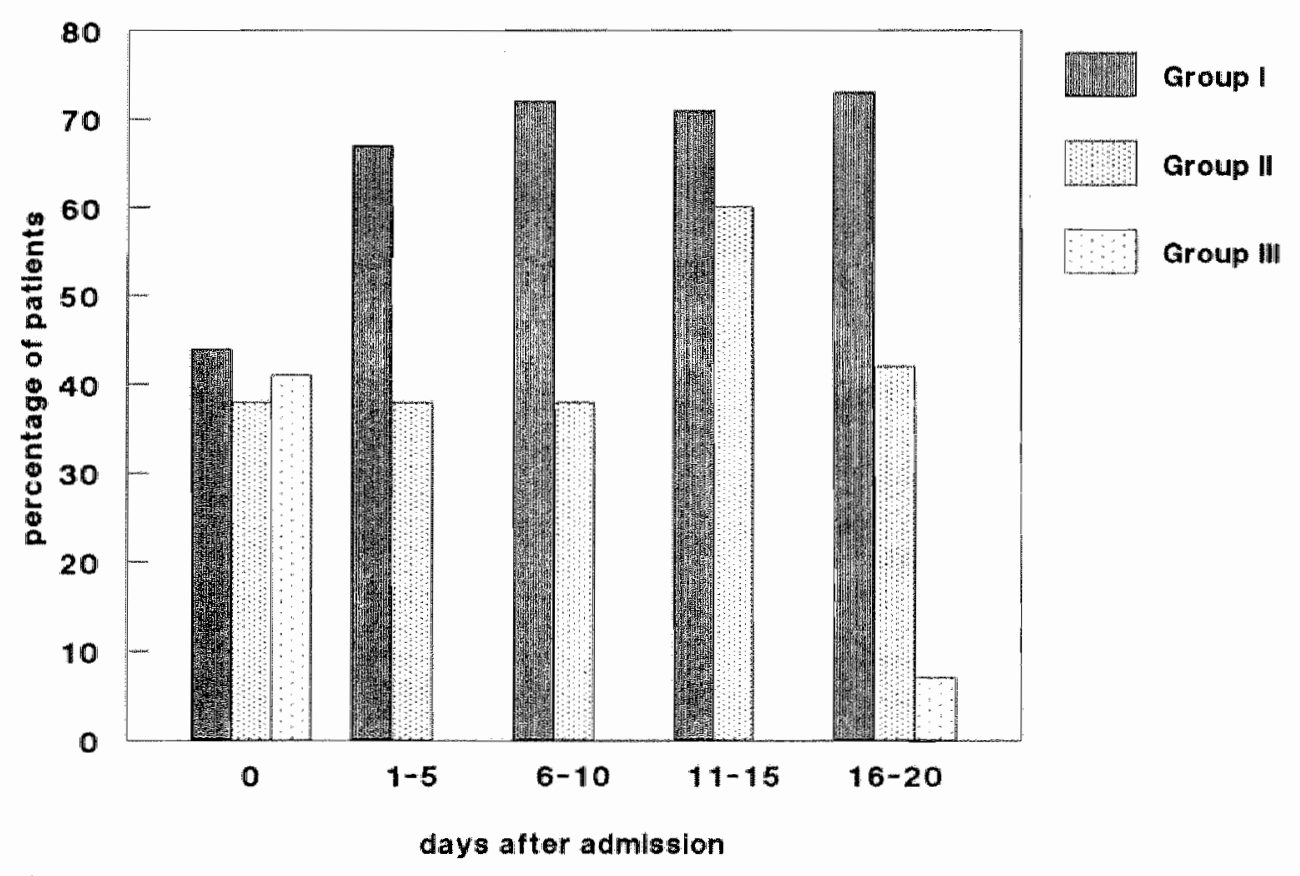

Figure 1 Colonization of the oropharynx with Gram-negative bacilli. 


\section{Colonization of the oropharynx}

\section{Gram-negative bacilli}

On admission, Gram-negative bacillary colonization of the oropharynx was present in about $40 \%$ of the patients in all three groups (Fig. I). In group I the Gramnegative bacillary colonization rate increased to more than $70 \%$, whereas in group

Table $V$ Intensive care acquired colonization of the oropharynx

\begin{tabular}{|c|c|c|c|}
\hline & $\begin{array}{l}\text { Group } 1 \\
(n=18)\end{array}$ & $\begin{array}{l}\text { Group 1I } \\
(n=21)\end{array}$ & $\begin{array}{l}\text { Group III } \\
(n=17)\end{array}$ \\
\hline \multicolumn{4}{|l|}{ Number of patients acquiring } \\
\hline new colonization oropharynxt & $15(83 \%)$ & $19(90 \%)$ & $2(12 \%)$ \\
\hline $95 \%$ confidence interval & $59-96 \%$ & $70-99 \%$ & $1-36 \%$ \\
\hline \multicolumn{4}{|c|}{ MICROORGANISMS INVOLVED ${ }^{*}$} \\
\hline Gram-positive bacteria & $3(10 \%)$ & $9(25 \%)$ & $\|(-)$ \\
\hline Enterococcus faecalis & 1 & 1 & - \\
\hline Staphylococcus aureus & 1 & 4 & - \\
\hline Other Streptococci & 1 & 4 & 1 \\
\hline Gram-negative bacilli & $21(72 \%)$ & $18(50 \%)$ & 0 \\
\hline Acinetobacter sp. & 1 & 2 & - \\
\hline Citrobacter sp. & 1 & 1 & - \\
\hline Enterobacter $\mathrm{sp}$. & 2 & 4 & - \\
\hline Escherichia coli & 9 & - & - \\
\hline Klebsiella sp. & 2 & 1 & - \\
\hline Morganella morganii & 1 & - & - \\
\hline Proteus mirabilis & 1 & 1 & - \\
\hline Pseudomonas aeruginosa & 4 & 6 & - \\
\hline Pseudomonas maltophiliat & - & 2 & - \\
\hline Serratia maresscens & - & 1 & $\ldots$ \\
\hline \multicolumn{4}{|l|}{ Other Gram-negative bacteria } \\
\hline Hacmophilus influenzae & $1(3 \%)$ & $6(17 \%)$ & 0 \\
\hline Yeasts & $4(14 \%)$ & $3(8 \%)$ & $1(-)$ \\
\hline Total" & 29 & 36 & 2 \\
\hline
\end{tabular}

* Several patients acquired more than one species of microorganisms.

$\dagger$ Overall $p<0.001$. Difference between Group I \& II not significant $(p=0.85)$, between Group I\& III $p=0.0001$, between Group II \& III $p<0.0001$. 
II it remained about $40 \%$ throughout ICU-stay. In group III, SDD and systemic antibiotic prophylaxis resulted in rapid elimination of all Gram-negative bacilli from the oropharynx.

In group I and group II, $83 \%$ and $90 \%$ of the patients respectively acquired microbial colonization - mainly with Gram-negative bacilli - of the oropharynx during their stay at the ICU (Table V). In group III, acquisition of new microorganisms - none of them Gram-negative bacilli-occurred only in $12 \%$ of the patients.

The effect of antibiotic therapy on colonization could be studied in 12 of the 18 patients of group I and in 18 of the 21 patients of group II.

In the 12 patients in group I, antibiotic therapy consisted of: ampicillin (seven patients), high dose penicillin (two patients) or flucloxacillin (three patients). All patients concurrently received gentamicin. In the first four days of antibiotic thera-

\section{(OROPMIANMWIX}
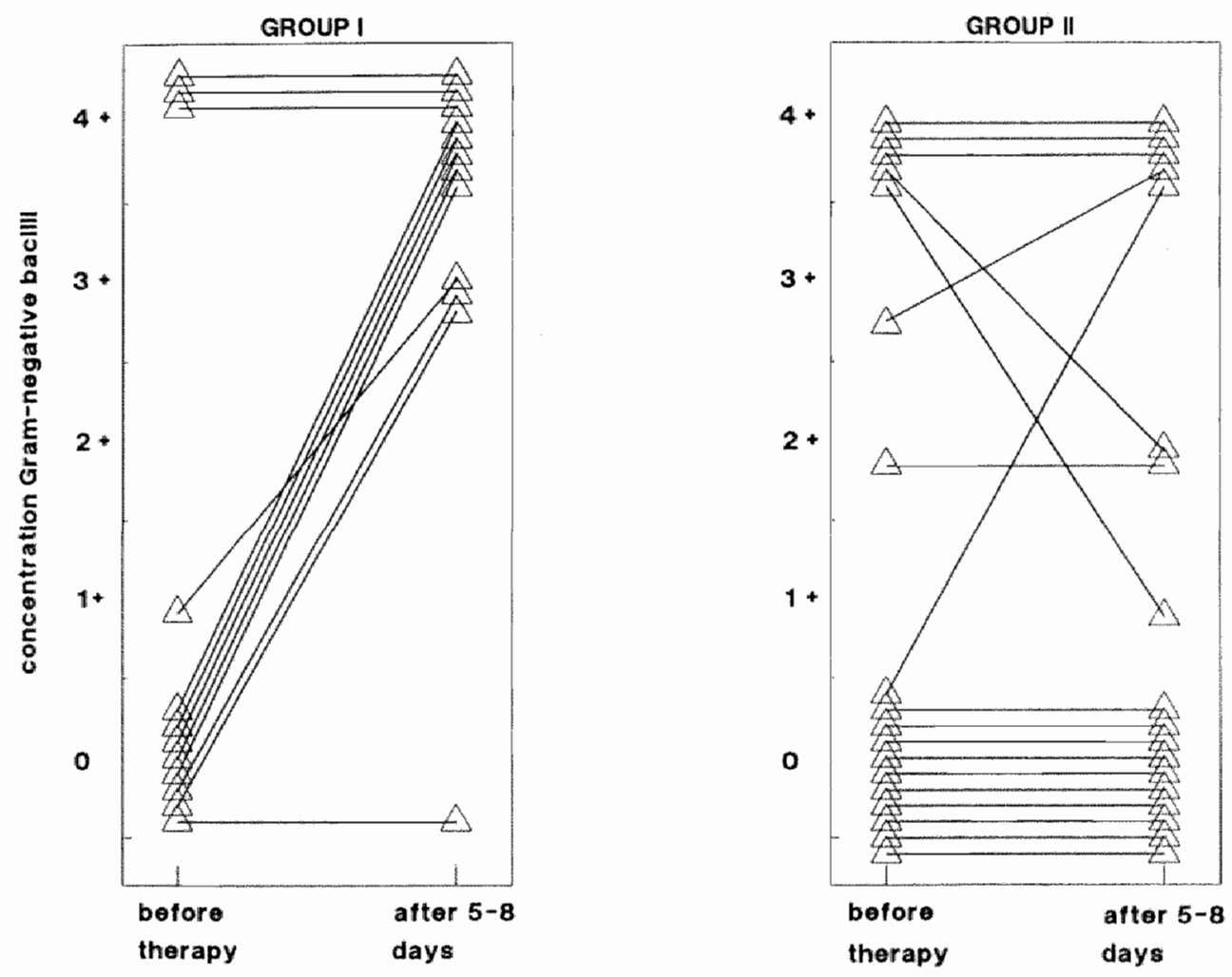

Figure 2 The influence of antibiotic therapy on the concentrations of Gramnegative bacilli in the oropharynx in Group I and Group II. The increase in concentration in Group I is statistically significant $(p=0.012)$, in Group II the concentration did not change. 
py, the concentration of Gram-negative bacilli did not change. However, cultures obtained five to eight days after the start of antibiotic therapy showed a significant increase of the concentration of Gram-negative bacilli in the oropharynx (Fig. 2). In the 18 patients of group II antibiotic therapy consisted of cefuroxime (11 patients), cefotaxime (three patients), cephradine (two patients) or cotrimoxazole (two patients). Cotrimoxazole was prescribed as monotherapy, the cephalosporins were combined with gentamicin on nine occasions. Administration of these antibiotics did not result in a change of the oropharyngeal concentration of Gramnegative bacilli (Fig.2).

\section{Commensal oropharyngeal flora}

Haemophilus influenzae was isolated from the oropharynx on admission in $44 \%$ of the patients in group I, in $29 \%$ in group II and in $24 \%$ in group III. In group I and group II, the rate of colonization with Haemophilus influenzae slightly decreased during ICU-stay. In all patients in group III, Haemophilus influenzae was eliminated from the oropharyn $x$ in a few days, that is, before the second culture (Fig. 3).

\section{MAENOPUILUS WFLUENZASE}

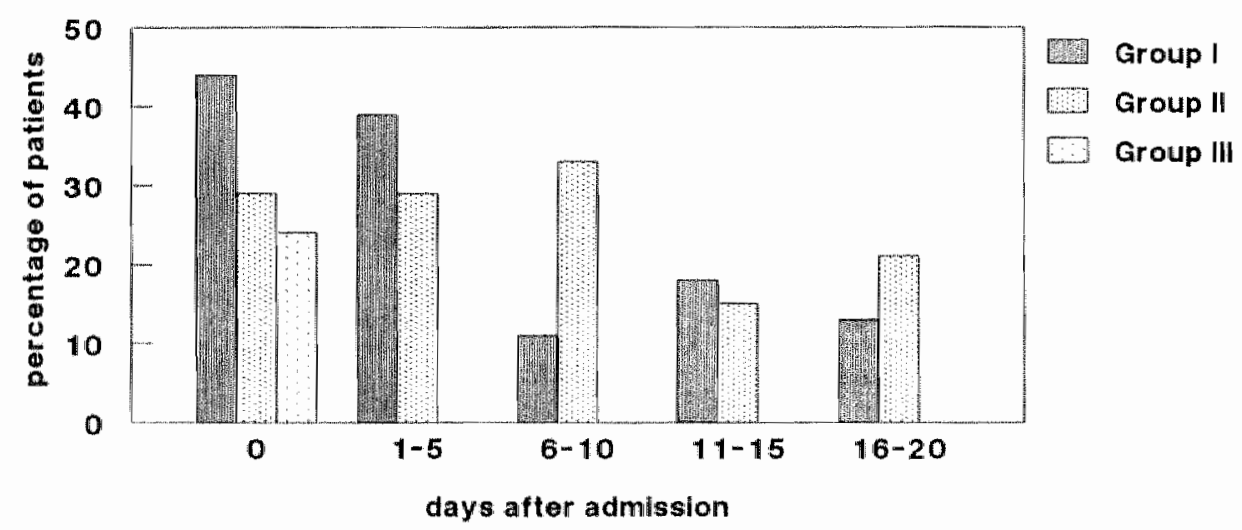

Figure 3 Colonization of the oropharynx with Haemophilus influenzae.

Only three patients (two in group II and one in group III) carried Streptococcus pneumoniae in their oropharynx on admission.

On admission, Staphylococcus aureus was cultured from the oropharynx in four patients in group I $(22 \%)$, two patients in group $I 1(10 \%)$ and five patients in group III $(30 \%)$. Celotaxime and SDD eliminated Staphylococcus aureus from the oropharynx within six days after admission in all five patients in group III. 
Yeasts

On admission, yeasts were cultured from the oropharynx of $48 \%$ of the patients in group I, 57\% in group II and $47 \%$ in group III. In group I and group II, this percentage slightly increased during admission at the ICU. In group III, yeasts were eliminated from the oropharynx in virtually all patients. Antibiotic therapy did not change the concentration of oropharyngeal yeasts in any of the groups.

\section{Colonization of the lower respiratory tract}

Colonization of the -normally sterile- lower respiratory tract was frequently present on admission. Microorganisms were cultured from the lower respiratory tract in nine of the 17 patients admitted without lower respiratory tract infection in group $I(53 \%)$, in nine of the 17 patients in group II $(53 \%)$ and in nine of the 14 patients in group $111(64 \%)$. The microorganisms involved are listed in Table VI. Staphylococcus aureus, Haemophilus infuenzae and, to a lesser extent, Streptococcus pneumoniae were most frequently involved. Gram-negative bacilli played a secondary role. In all patients with microbial colonization of the lower respiratory tract on admission, the colonizing microorganism could, at the same time, be cultured from the oropharynx. This suggests that aspiration of oropharyngeal contents frequently occurs in an early phase of acute disease.

Table VI Microorganisms colonizing the lower respiratory tract on admission.

\begin{tabular}{lllll}
\hline & Group I & Group II & Group III & Total \\
\cline { 3 - 5 } & 1 & 4 & 2 & 7 \\
Haemophilus intluenzae & 1 & 2 & 5 & 10 \\
Streptococcus pneumoniae & $-\ldots$ & 2 & - & 2 \\
Gram-negative bacilli & 5 & 3 & - & 8 \\
Other microorganisms & - & 1 & 2 & 3 \\
\hline
\end{tabular}

Note: some patients were colonized by more than one microorgasnism.

Lower respiratory tract colonization was eliminated by the short course of cefotaxime in all patients in group III. In both control groups, colonization of the lower respiratory tract frequently persisted. In seven cases (three in group I and four in group II) a microorganism that already colonized the lower respiratory tract on admission later gave rise to lower respiratory tract infection. 


\section{Gran-negative bacilli}

The percentage of patients carrying Gram-negative bacilli in the stomach on admission was $50 \%$ in group I, 19\% in group II and $29 \%$ in group III (no significant differences). In both group I and group II, the rate of Gram-negative bacillary colonization of the stomach increased to more than $50 \%$ during admission (Fig.4).

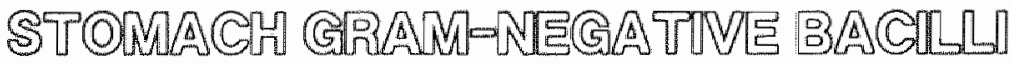

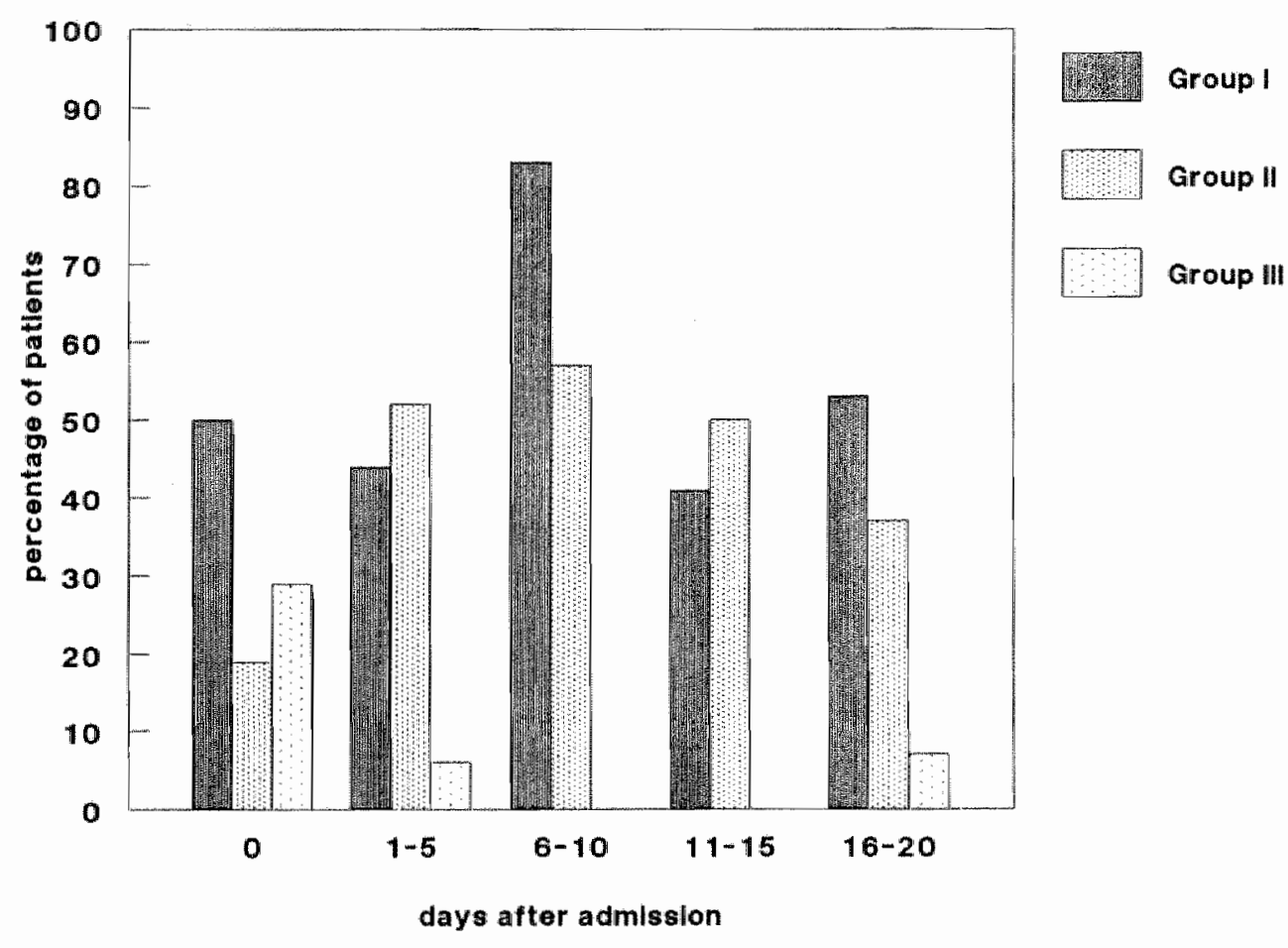

Figure 4 Colonization of the stomach with Gram-negative bacilli.

In group III, nearly all Gram-negative bacilli were eliminated from the stomach and the acquisition of new Gram-negative bacilli was prevented, except in one patient to whom the antibiotics used for SDD were not properly applied. Table VII gives the newly acquired microorganisms in the three groups.

Antibiotic therapy in group I was followed by a significant increase of the concenIration of Gram-negative bacilli in the stomach. Like in the oropharynx, this increase in concentration became manifest five to eight days after the start of anti- 
Table VII Intensive care acquired colonization of the stomach.

\begin{tabular}{|c|c|c|c|}
\hline & $\begin{array}{l}\text { Group I } \\
(n=18)\end{array}$ & $\begin{array}{l}\text { Grotup II } \\
(n=2 \|)\end{array}$ & $\begin{array}{l}\text { Group lil } \\
(n=17)\end{array}$ \\
\hline \multicolumn{4}{|l|}{ Number of patients acquiring } \\
\hline new colonization of the stomacht & $17(94 \%)$ & $19(90 \%)$ & $4(24 \%)$ \\
\hline $95 \%$ confidence interval & $73-100 \%$ & $70-99 \%$ & $7-50 \%$ \\
\hline \multicolumn{4}{|l|}{ MICROORGANISMS INVOLVED* } \\
\hline Gram-positive bacteria & $8(20 \%)$ & $9(26 \%)$ & $4(-)$ \\
\hline Enterococcus faecalis & 8 & 9 & 4 \\
\hline Gram-negative bacilli & $27(66 \%)$ & $20(59 \%)$ & $1(-)$ \\
\hline Acinetobacter sp. & 1 & 3 & 1 \\
\hline Enterobacter sp. & 4 & 4 & - \\
\hline Escherichia colli & 10 & 1 & - \\
\hline Klebsiellasp. & 5 & 4 & - \\
\hline Morganella morganii & - & 1 & - \\
\hline Proteus mirabilis & 2 & - & - \\
\hline Pseudomonas aeruginosa & 4 & 5 & - \\
\hline Serratia marcescens & - & 1 & - \\
\hline other Gram-negative bacilli & 1 & 1 & - \\
\hline Yeasts & $6(15 \%)$ & $5(15 \%)$ & $1(-)$ \\
\hline Candida albicans & 5 & 2 & - \\
\hline Other yeasts & 1 & 3 & 1 \\
\hline Total* & 41 & 34 & 6 \\
\hline
\end{tabular}

* Several patients acquited more than one species of mictorganisms.

$\dagger$ Overall $p<0.001$. Difference between Group I \& II not signilicant $(p=1.00)$, between Group I\& III $p<0.0001$, between Group II \& III $p<0.0001$.

biotic therapy. In group II, there was only a small, non-significant, increase in the concentration of Gram-negative bacilli in the stomach following antibiotic therapy (Fig.5).

\section{Gram-positive cocci}

The number of patients exhibiting gastric colonization with Gram-positive cocci rose from $15 \%$ on admission to about $30 \%$ in both control groups. In group III the rate of gastric colonization with Gram-positive cocci decreased from 18\% on admission to zero after ten days of SDD. However, Gram-positive cocci were not persistently eliminated from the stomach in all patients: four patients in group III 


\section{STOMACH}
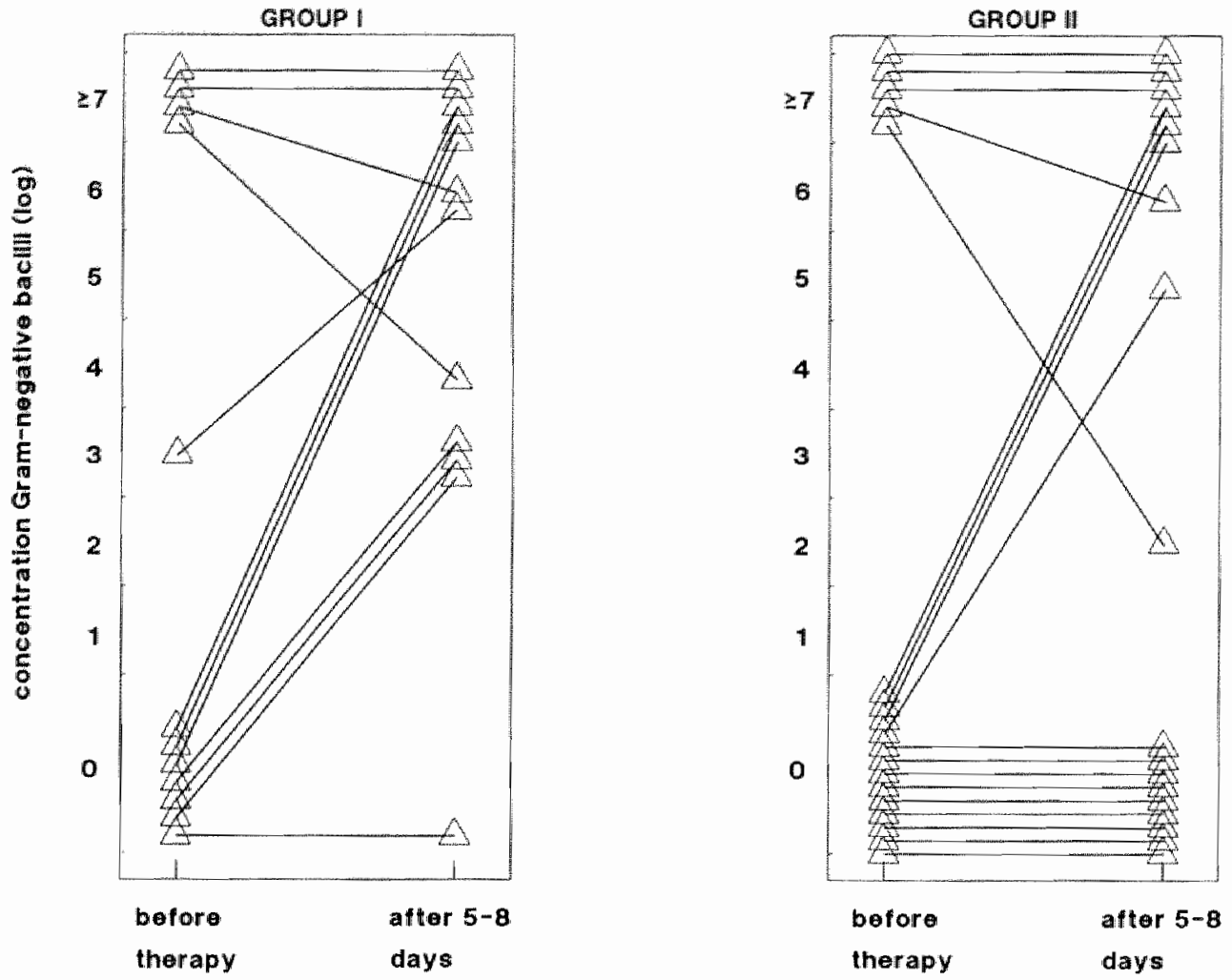

Figure 5 The influence of antibiotic therapy on the concentrations of Gramnegative bacilli in the stomach in Group I and Group II. The increase in concentration in Group I is statistically significant $(p=0.029)$, in Group II the increase in concentration is nor significant $(p=0.17)$.

acquired Enterococcus faecalis, a microorganism which is only moderately susceptible to norfloxacin.

\section{Yeasts}

On admission, yeasts were cultured from the stomach of $33 \%$ of the patients in group I, $62 \%$ in group II and $47 \%$ in group III. In group I and group II, this percentage remained approximately the same throughout the study. In group III the colonization rate was reduced to $7 \%$. Antibiotic therapy did not influence the concentration of yeasts in the stomach. 
RIECTUM ECOLI

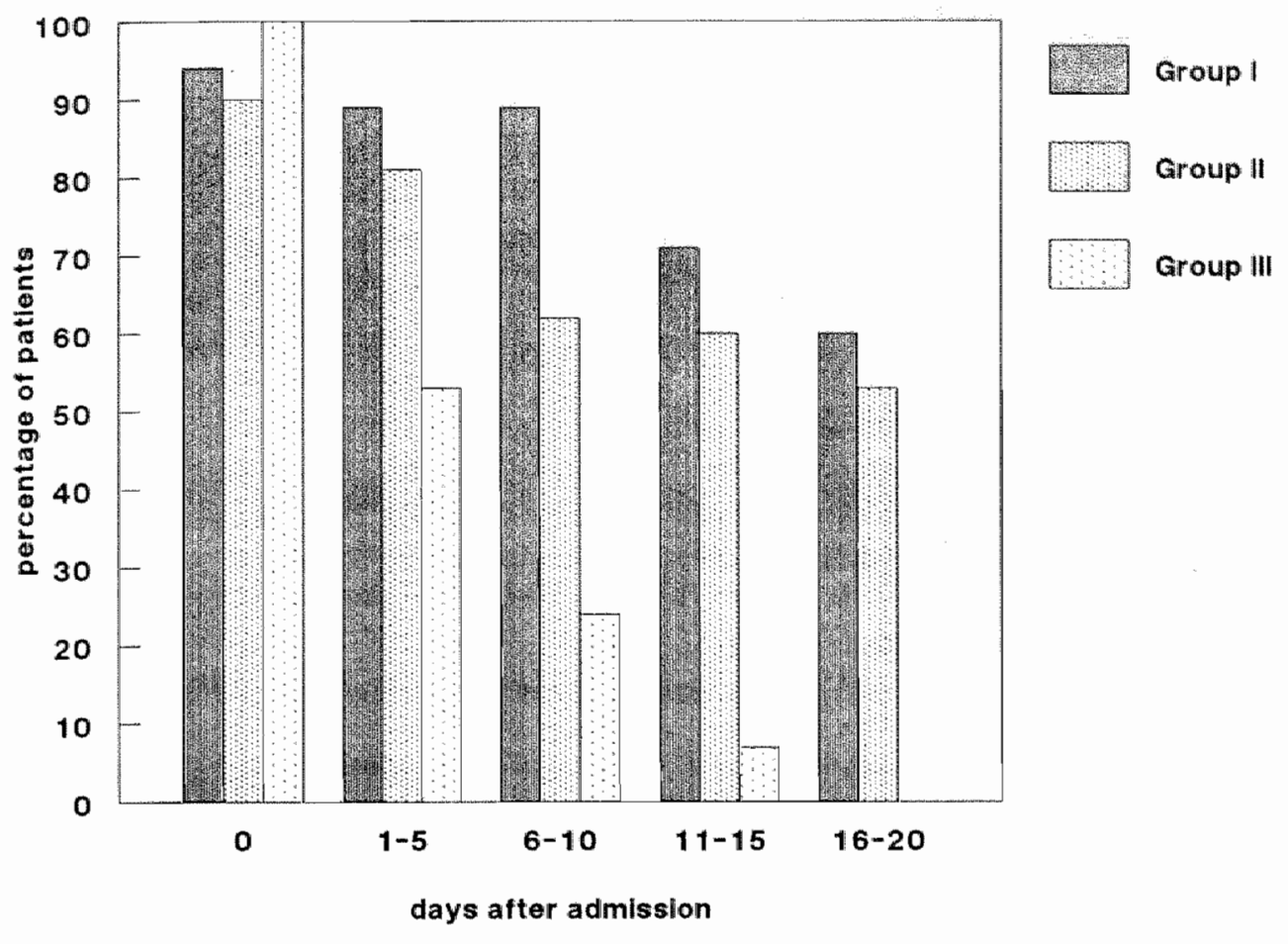

IRECTUM OTIIER GRAN=NEGATINE BACML]

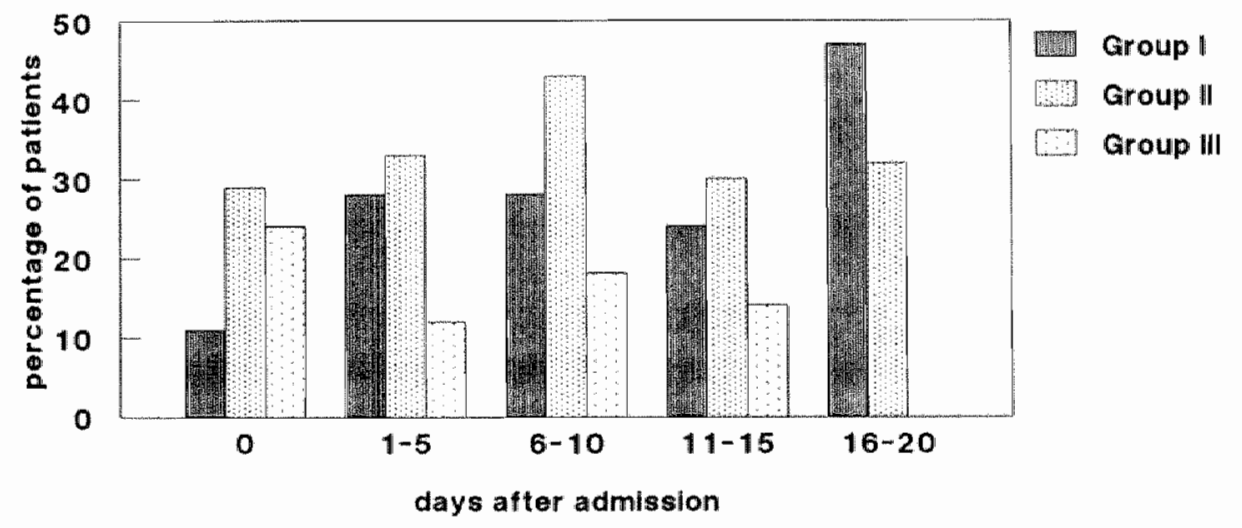

Figure 6 Colonization of the rectum wirh E.coli and other Gram-negative bacilli. 


\section{Gram-negative bacilli}

On admission Escherichia coli was cultured from the rectum of virtually all patients (Fig, 6). In all groups, the incidence of rectal colonization with E.coli decreased during admission. In both control groups the decrease was not significant. SDD was very effective in eliminating $E$.coli from the lower digestive tract: in all group III patients, decontamination of the rectum from $E$.coli was achieved after the first defaecation. However, since bowel movements were impaired in many patients, it sometimes took more than ten days for decontamination of the rectum to occur.

Colonization of the rectum with other microorganisms than E.coli occurred frequently in groups I and II (Fig.6 and table VIII). In group III, three patients acquired transient colonization with Gram-negative bacilli susceptible to norfloxacin.

Table VIII Intensive care acquired Gram-negative bacillary colonization of the rectum (E.coli not included).

$\begin{array}{lll}\text { Group I } & \text { Group II } & \text { Group III } \\ (n=18) & (n=20) & (n=17)\end{array}$

Nimber of patients acquiring new Gram-negative bacillary colonization of the nectum

$95^{\circ}$ confidence interval

$\begin{array}{lll}14(78 \%) & 14(67 \%) & 3(18 \%) \\ 52-94 \% & 43-85 \% & 4-43 \%\end{array}$

\section{Gram-negative bacilli}

$\begin{array}{lccc}\text { Acinetobacter sp. } & 3 & 4 & \text { - } \\ \text { Citrobactar sp. } & 4 & 3 & - \\ \text { Enterobucter sp. } & 3 & 5 & - \\ \text { Klebsiella sp. } & 5 & 6 & - \\ \text { Morganella morganii } & \| & - & - \\ \text { Proteus sp. } & 3 & 2 & 2 \\ \text { Psendomonas aeruginosa } & 4 & 8 & \end{array}$

Totals*

23

* Some patients acquired more than one species of Gram-negative bacilli.

+ Overall $p<0.001$. Difference between Group $1 \& 11$ not significant $(\mathrm{p}=0.68$ ), between Group I $111 \mathrm{p}<0.001$, between Group II \& III $p<0.006$ 


\section{Gram-positive cocci}

Gram-positive microorganisms cultured from the rectum were all Enterococcus faecalis, except for a Staphylococcus epidermidis cultured from one patient in group III.

\section{Intensive care acquired lower respiratory iract infection}

Detailed information about the lower respiratory tract infections that occurred during this study has been provided elsewhere (chapter V). The results can be summarized as follows: in group I, 14 patients (78\%) acquired lower respiratory tract infection. Several patients in group I acquired more than one lower respiratory tract infection, and the total number of respiratory tract infections in this group was 25.

In group II, 13 patients ( $62 \%$ ) acquired 22 lower respiratory tract infections. Only one patient in group III $(6 \%)$ acquired a lower respiratory tract infection.

Almost all lower respiratory tract infections in both control groups were endogenous (Fig.7). Of the 25 lower respiratory tract infections in group $1,23(92 \%)$

\section{GROUP [ ]}

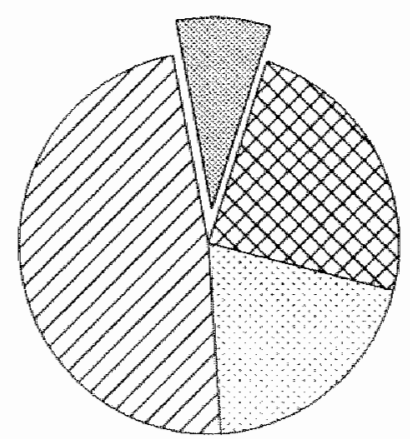

exogenous $8 \%$

oropharynx $48 \%$

stomach $20 \%$

oropharynx and

stomach $24 \%$

\section{GROบ円 [I]}

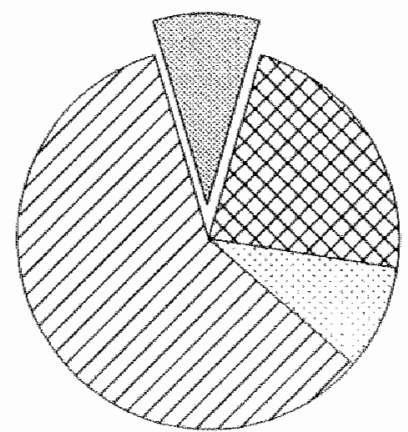

exogenous $9 \%$
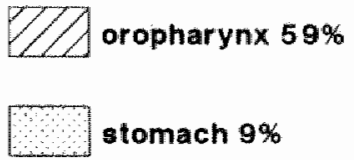

oropharrynx and

stomach $23 \%$

Figure 7 Origin of microorganisms causing lower respiratory tract infection in group I and group II. 
were endogenous. In five cases the causative microorganism was first cultured from the stomach, in 12 cases the oropharynx was the primary site of colonization. In the remaining six cases, microorganisms were cultured simultaneously from both oropharynx and stomach.

In group II, 20 of the 22 lower respiratory tract infections (91\%) were preceded by colonization of the stomach (two patients), the oropharynx (13 patients) or both (five patients).

Three of the four exogenous infections were preceded by colonization of the nose with the causative microorganism.

The only infection in group III was not preceded by colonization at any site and probably resulted from direct cross-contamination.

\section{Antibiotic therapy}

Even though, in both control groups, a restrictive antibiotic policy was followed, seventeen patients in group $1(94 \%)$ and all 21 patients in group II received antibiotic therapy, mostly from an early stage (Table IX). In group III only 11 patients $(65 \%)$ required antibiotic therapy. The antibiotic use, as expressed as the number of antibiotic days per patient (one antibiotic day is use of one antibiotic during one day) or as the number of antibiotic courses per patient, in group III is less than in both control groups. Even if the five day course of cefotaxime given to all patients in group III is included, the antibiotic use in this group is still lower than in both control groups.

Table IX further specifies the number of patients receiving particular antimicrobial agents. All but one patient in group I received one or more courses of therapy with high dose penicillin ( $\geq 10^{6}$ tid) or with a penicillin derivative (ampicillin, amoxicillin, llucloxacillin), antibiotics that are known to disturb MCR (chapter I). In groups II and III, the use of antibiotics was restricted to those that are known not to disturb MCR.

The application of our regime of SDD and systemic cefotaxime was not accompanied by an increase of the incidence of resistance against the antibiotics used. However, these data should be interpreted with some caution since only 17 patients were treated with the regime $(95 \%$ confidence interval $0-16 \%)$.

\section{Discussion}

The use of antibiotics disturbing MCR in group I led to a significant increase in the concentrations of Gram-negative bacilli in oropharynx and stomach, whereas in group Il the use of antibiotics not influencing MCR did not have this effect. Aspi- 


\begin{tabular}{|c|c|c|c|}
\hline & $\begin{array}{l}\text { Groupl } \\
(n=18)\end{array}$ & $\begin{array}{l}\text { Group 11 } \\
(n=21)\end{array}$ & $\begin{array}{l}\text { Gitoup lll } \\
(n=17)\end{array}$ \\
\hline Patients receiving antibiotic therapy & $17(94 \%)$ & $21(100 \%)$ & $\|(65 \%)$ \\
\hline $95 \%$ confidence interval & $73-100 \%$ & $84-100 \%$ & $38-86 \%$ \\
\hline $\begin{array}{l}\text { Mean number of antibiotic } \\
\text { courses/patient } \dagger\end{array}$ & 5.2 & 3.2 & $1.5 *$ \\
\hline $\begin{array}{l}\text { Mean number of antibiotic } \\
\text { days/patient t+ }\end{array}$ & 42 & 26 & $13^{\text {争 }}$ \\
\hline \multicolumn{4}{|l|}{ Number of patients receiving: } \\
\hline Antimycotics & $3(17 \%)$ & $2\left(10^{\circ} \%\right)$ & $2\left(12^{o}\right)$ \\
\hline Aminoglycosides & $16\left(89^{\mathrm{m}} \%\right)$ & $12(57 \%)$ & $4(24 \%)$ \\
\hline Cefotaxime & - & $5(24 \%)$ & $3(18 \%)^{*}$ \\
\hline Other cephalosporins & $5(28 \%)$ & $20(95 \%)$ & $7(41 \%)$ \\
\hline Penicillins & $17(94 \%)$ & - & - \\
\hline Metronidazole & $3(17 \%)$ & $6(29 \%)$ & $3(18 \%)$ \\
\hline Cotrimoxazole & $1(6 \%)$ & $8(38 \%)$ & $3(18 \%)$ \\
\hline Other antibiotics & $12(67 \%)$ & $5(24 \%)$ & $2(12 \%)$ \\
\hline
\end{tabular}

* The initial five day course of cefotaxime is not included.

7. Overall $p=0.0001$. Difference between Group I \& II $p=0.046$, between Group I \& III $p=0.0002$, between Group II \& III $p=0.0007$.

it Overall $p=0.001$. Difference between Group I \& 11 II.s. $(p=0.12)$, between Group I \& III $p=0.0017$, between Group II \& III $p=0.0027$.

ration of oropharyngeal and gastric contents plays a pivotal role in the development of lower respiratory tract infection (chapter II). Higher concentrations of microorganisms in oropharynx and stomach will result in higher numbers of bacteria reaching the lower respiratory tract in case of aspiration. In an animal experiment, intratracheal instillation of a bolus of $10^{4}$ microorganisms produced severe infection [Berendt, 1978]. If the concentration of microorganisms in oropharynx or stomach exceeds $10 \% \mathrm{ml}$, this threshold can easily be passed, with a consequent increase of the risk of lower respiratory tract infection. Therefore, the use of antibiotics that do not affect MCR is to be preferred. The great variety of antibiotics currently available makes it possible to effectively treat most infections without disturbing MCR.

In all patients with early lower respiratory tract infection (occurring within five days after admission), this infection was caused by microorganisms that already colonized the oropharyn $x$ on admission (chapter $V$ ). In half of these patients the 
causative microorganism had already colonized the lower respiratory tract on admission. If the spread of microorganisms to the lower respiratory tract has already occurred, SDD alone is not effective. Our regime of SDD in association with short-term cefotaxime eliminated all potentially pathogenic microorganisms from the lower respiratory tract. The effect of norfloxacin and polymyxin $E$ is limited to oropharynx, stomach and lower digestive tract. Therefore, the elimination of microorganisms from the lower respiratory tract and the prevention of early lower respiratory tract infection can be completely attributed to cefotaxime. Cefotaxime $500 \mathrm{mg}$ tid proved adequate in this study.

In the control groups, the acquisition of new Gram-negative bacilli in both oropharynx and stomach was a frequent event. In group III protection against the acquisition of new microorganisms (especially against Gram-negative bacilli) persisted long after cefotaxime prophylaxis was discontinued, and is therefore thought to be achieved by SDD.

To achieve persistent decontamination of the oropharynx, the use of antibiotics in a sticky mouth paste that slowly releases constant amounts of the drugs is essential [Stoutenbeek, 1987]. Other methods of topical administration of antibiotics may result in fluctuating oropharyngeal concentrations of antibiotics that will mostly be too low to be effective.

The administration of antibiotics via the gastric tube is important to prevent gastric colonization. It should be continued even if, like in most of our patients, peristalsis is impaired. If bowel movements are normal, a rapid decontamination of the whole digestive tract from aerobic Gram-negative bacilli will occur. This eliminates a major source of urinary tract infection [Daifuku, 1974], of cross-infections [Penn, 1981], of wound infections [Van Saene, 1979] and of colonization of the patients own oropharynx [Le Frock, 1979]. Moreover, successful elimination of intestinal Gram-negative bacilli is likely to prevent endotoxaemia via reduction of the faecal endotoxin pool.

The possible emergence of antibiotic resistance still remains a concern. Problems may arise both from the selective pressures for resistance imposed by the regime of SDD and, possibly, from the induction of B-lactamases in certain species of Gram-negative bacilli during the initial periods of cefotaxime therapy [BrunBuisson, 1987; Livermore, 1987]. However, in our study as well as in others [Stoutenbeek, 1984,A; Kerver, 1987; Unertl, 1987], the alternative of traditional management (i.e. administration of antibiotics only on clinical evidence of infection) involved extensive use of a wide range of antibiotics and hence the same potential problems.

Moreover, SDD is specifically designed to prevent colonization or overgrowth with antibiotic-resistant strains, and the extensive microbiological surveillance should allow early detection of problems and prompt institution of control measures |Alcock, 1988]. 
So far, the results with SDD and systemic antibiotic prophylax is are encouraging: despite careful monitoring, problems of resistance have not been encountered in our study nor in others [Stoutenbeek, 1984; Kerver, 1988: Ledingham, 1988], even though a regime of SDD and systemic prophylaxis has been used in one center for 30 months [Stoutenbeek, 1987, A].

The regime of SDD described in this study proved to be at least as effective as the PTA-regime, which most other authors used [Stoutenbeek. 1984; Kerver, 1988 ; Ledingham, 1988]. In our opinion the regime we studied is to be preferred over the PTA-regime. The use of norfloxacin instead of tobramycin is not only less expensive, but also safer on theoretical grounds. In humans the decontaminating range of tobramycin appears to be narrow. MCR may be disturbed at daily doses of 300 mg of orally administered tobramycin, which is the daily dose used for SDD [Mulder, 1984]. This might, in case of contamination with a microorganism resistant to all antimicrobial agents used, facilitate colonization with - and the outgrowth of - this microorganism to high concentrations, with consequent risk of infection and of contamination of other patients. Norfloxacin, in the dose used in this study, does not disturb MCR [De Vries-Hospers, 1985].

Another disadvantage of oral tobramycin is that, although the agent is poorly absorbed, detectable serum levels may occur. It was reported that, in patients with renal failure, the serum tobramycin level may even exceed $2 \mathrm{mg} / \mathrm{L}$ with the consequent risk of ototoxicity and nephrotoxicity [Sciarra, 1988]. Norfloxacin is absorbed from the digestive tract, but has no serious side-effects [Corrado, 1987].

However, because the administration of norfloxacin resulted in the development of cartilage erosions in juvenile animals of some species [Corrado, 1987], it is recommended note to use norfloxacin in patients whose skeletal growth is incomplete.

\section{Conclusion}

In this study in patients requiring prolonged mechanical ventilation, a novel regime of SDD, in combination with short-term systemic celotaxime, effectively eliminated potentially pathogenic microorganisms from oropharynx and stomach. Moreover, the regime put an end to colonization of the lower respiratory tract with commensal oropharyngeal flora, which was frequently present on admission. SDD prevented the acquisition of new microorganisms in oropharynx and stomach.

The influence of SDD and short-term systemic cefotaxime on the lower respiratory tract infection rate will be discussed in the next chapter. 


\section{References}

Alcock SR, Lodingham IMCA, Selectiwe decontamination of the digestive tract and prevention of infection in intensive care units. J Antimicrob Chemother 1988;22:97 101.

Berend RF. Relationship of method of administration to resporatory virulence of Klebsiella pneurnoniae for rnice and squirrel monkeys. Infect Immun 1978; 20:581-583.

Brum-Buisson C, Legrand P, Philippon A, Moniravers F, Ansquer M, Daval J. Transferable enzymatic resistance to third generation cephalosporins during nosocomial outbreak of multiresistant Klebsiella pneumoniae. Lancet 1987 ; ii: 302.6.

Corado ML, Struble WE, Peter C. Hoagland V, Sabbaj J. Norfloxacin: review of safety studies. Am J Med 1987: 82(suppl 6B): 22-6.

Datfuku R, Stamm WE. Association of rectal and urethral colonization with urinary tract infection in patients with indwelling catheters. JAMA 1984; 252: 2028-30.

De Vries-Hospers HG, Welling GW. Van der Waaij D. Norfloxacin for selective decontamination: a study in human volunteers. In: Wostmann BS, ed. Germfree research: microflora control and its application to the biomedical sciences. New York: Alan R. Liss, 1985: 259-62.

Kerver AJH, Rommes JH, Mevissen-Verhage EAE, et al. Colonization and infection in surgical intensive care pationis. Intensive Care Med 1987; 13; 347-51".

Kerver AJH, Rommes JH, Mevissen-Verhage EAE, et al. Prevention of colonization and infection in critically ill patients. Crit Care Med 1988; 16:1087-93.

Le Frock JL, Ellis CA, Weinstein L. The relation between aerobic fecal and oropharyngeal microflora in haspitalized pattients. Am J Med Sci 1979; 277: 275-280.

Ledingham IMcA, Alcock SR, Eastaway AT, McDonald JC, Mckay IC, Ramsay G. Triple regimen of selective decontamination of the digestive tract, systemic cefotaxime, and microbiological surveillance for prevention of acquired infection in intensive care. Lancet 1988;i: 785-90.

Livermore DM. Clinical significance of beta-lactamase induction and stable derepression in gramnegative rods. Europ J Clin Microbiol 1987; 6: 439-45.

Mulder JG, Wiersma WE, Welling GW, Van der Waaij D. Low dose oral tobramycin treatment for selective decontamination of the digestive tract: a study in human volunteers. I Antimicrob Chemother $1984 ; 13 ; 495-504$.

Penn RG, Sanders WE. Sanders CC. Colonization of the oropharynx with Gram-negative bacilli: A major antecedent to nosoconaial pneumonia. Am J Infect Contr 1981; 9:25-34.

Sciarta M, Cavaliere F, Crociani $E_{*}$ Ciuni $C$, Proietti $R$. Tobramycin serum levels during selective decontamination of the digestive tract [Abstract]. Intensive Care Med 1988; 14 (suppl 1): 311 .

Stoutembeek ChP, Van Saene HKF, Miranda DR, Zandstra DF. The effect of selective decontamination of the digestive tract on colonization and infection rate in multiple trauma patients. Intensive Care Med 1984: 10: 185-92

Stoutenbeek ChP, Van Saene HKF, Miranda DR, Zandstra DF, Binnendijk B. The prevention of superinfections in multiple trauma patients. J Antimicrob Chemother 1984 A; 14 (suppl B): 203-11.

Sioutenbeck ChP, Van Saene HKF, Miranda DR" Zandstrat DF, Lingrehr D. The effect of oropharyngeal decontamination using topical nonabsorbable antibiotics on the incidence of nosocomial respiratory tract infections in multiple trauma patients. J Trauma 1987; 27: 357-64.

Stoutenbeek CP. Van Saene HKF", Zandstra DF. The effect of nonabsorbable antibiotics on the emergence of resistant bacteria in patients in an intensive unit. J Antimicrob Chenother 1987 A; 19: 513.20 .

Unertl K, Ruckdeschel G, Selbmann HK, et al. Prevention of colonization and respiratory infections in long-term ventilated patients by local antimicrobial prophylaxis. Intensive Care Med $₫ 987$; 13 : $106-13$

Van Saene HKF, Nicolai JPA. The prevention of wound infections in bum patients. Scand J Plast Reconstr Surg 1979; 13:63 


\section{CHAPTER V}

\section{Selective decontamination and short-term systemic antibiotic prophylaxis in mechanically ventilated patients: clinical results.}

\section{Results}

\section{Study population}

Information about the population studied has been provided in chapter IV.

\section{Colonization of the oropharynx}

In both group II and II over $80 \%$ of the patients acquired one or more new species of microorganisms in the oropharynx during intensive care stay, predominantly Gram-negative bacilli (Table 1)

Table I Intensive care acquired colonization of oropharynx and stomach

\begin{tabular}{|c|c|c|c|}
\hline & $\begin{array}{l}\text { Group I } \\
(n=18)\end{array}$ & $\begin{array}{l}\text { Group II } \\
(n=21)\end{array}$ & $\begin{array}{l}\text { Group I1 } \\
(n=17)\end{array}$ \\
\hline \multicolumn{4}{|l|}{ Number of patients acquiring } \\
\hline $95 \%$ confidence interval & $59-96 \%$ & $70-99 \%$ & $1-36 \%$ \\
\hline \multicolumn{4}{|l|}{ Microorganisms involved ${ }^{\text {th }}$} \\
\hline Gram-negative bacteriat & $22(76 \%)$ & $24(67 \%)$ & $0(-)$ \\
\hline Gram-positive bacteria & $3(10 \%)$ & $9(25 \%)$ & $1(-)$ \\
\hline Yeasts & $4(14 \%)$ & $3(8 \%)$ & $1(-)$ \\
\hline \multicolumn{4}{|l|}{ Number of patients acquiring } \\
\hline new colonization of the stomacht & $17(94 \%)$ & $19(90 \%)$ & $4(24 \%)$ \\
\hline $95 \%$ confidence interval & $73-100 \%$ & $70-99 \%$ & $7-50 \%$ \\
\hline \multicolumn{4}{|l|}{ Microorganisms involved ${ }^{\text {th }}$} \\
\hline Gram-negative bacteria & $27(66 \%)$ & $20(59 \%)$ & $1(-)$ \\
\hline Gram-positive bacteria & $8(20 \%)$ & $9(26 \%)$ & $4(-)$ \\
\hline Yeasts & $6(15 \%)$ & $5(15 \%)$ & $1(-)$ \\
\hline
\end{tabular}

$+\quad$ Overall $p<0.001$. Difference between Group I \& II not significant $(p=0.85)$, between Group I \& III $p=0.0001$, between Group II \& III $p<0.0001$.

tt Overall $p<0.001$. Difference between Group I \& II not significant $(p=1.00)$, between Group I \& III p $<0.0001$, between Group II \& III $p<0.0001$. 
Acquisition of more than one new species of microorganisms occurred frequently in both group I and group II (Fig. 1a). Acquisition of Gram-negative bacilli was completely prevented in patients receiving selective decontamination (group III). Two patients in this group acquired new microorganisms in their oropharynx: a $\alpha$ haemolytic streptococcus (not susceptible to the topically applied antibiotics) and one yeast (susceptible to amphotericin B).
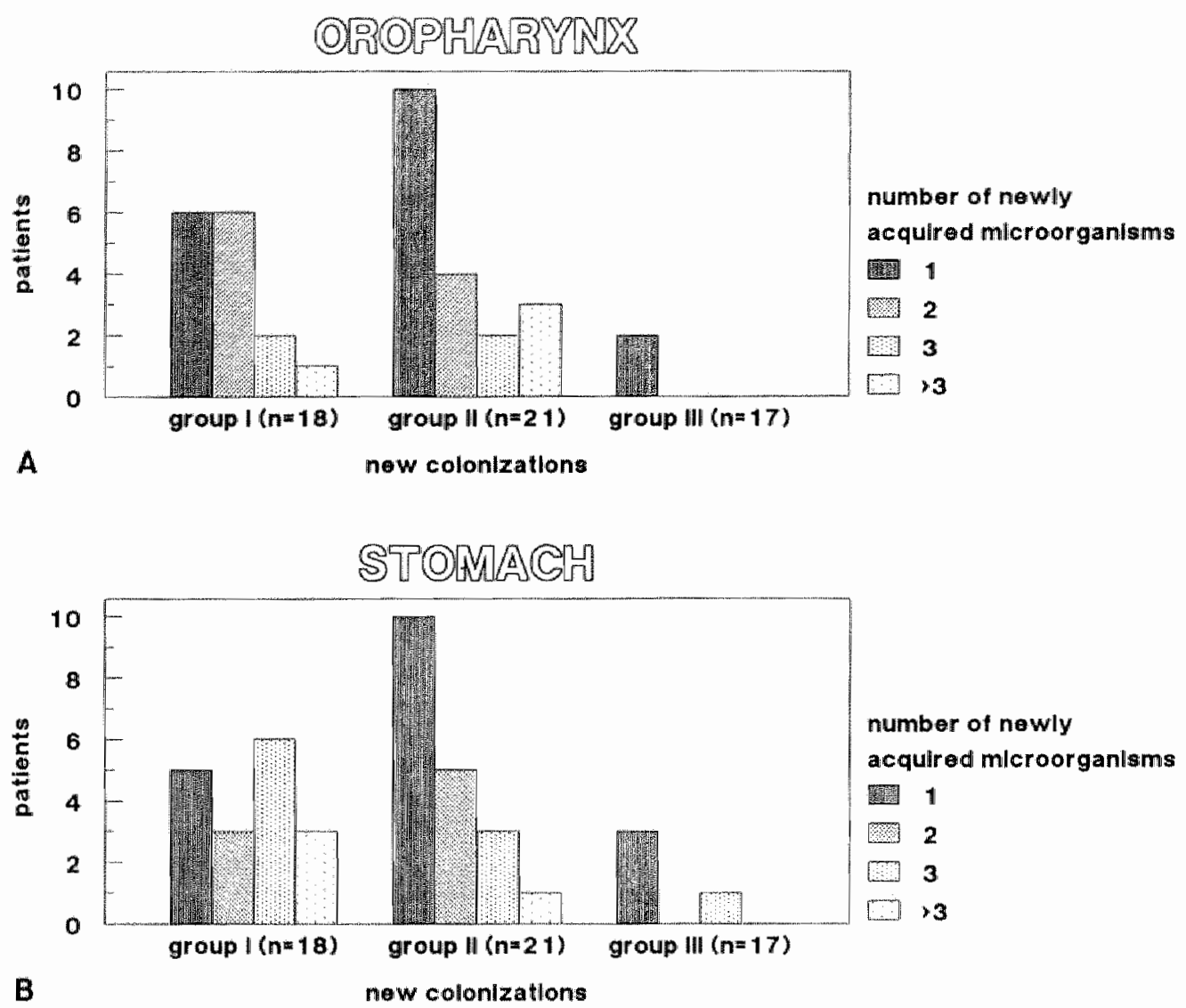

Figure I Number of newly acquired species of microorganisms per patient in the oropharynx (fig. Ia) and in the stomach (fig. lb).

\section{Colonization of the stomach}

Acquisition of new microorganisms, mostly Gram-negative bacilli, in the stomach occurred in about $90 \%$ of the patients in groups I and II (Table I), frequently with more than one microorganism (Fig. Ib). Colonization of the stomach with Gramnegative bacilli was virtually completely prevented in group III patients. The only 
exception was the isolation in one patient of an Acinetobacter anitrans susceptible to the trial medication. From the stomach of this patient two other newly acquired microorganisms were isolated, probably due to improper application of the antibiotics (suction was applied to the nasogastric tube immediately after administration of the trial medication). The Gram-positive bacteria isolated from the stomach in the three groups were all enterococci.

More detailed information about colonization of the oropharynx and the stomach was provided in chapter IV.

\section{Lower respiratory tract infection}

Fourteen patients in group I ( $78 \%)$ and 13 patients in group II $(62 \%)$ acquired at least one lower respiratory tract infection (Table III). Several patients in both control groups acquired more than one respiratory tract infection. The 14 patients in group I together acquired 25 infections and for the 13 patients in group II the number of infections was 22 . Of the 47 infections in both control groups, $43(91 \%)$ were of endogenous origin. In seven cases the causative organism was tirst cultured from the stomach and in 25 cases the oropharynx first became colonized. In the remaining 11 cases microorganisms were cultured simultaneously from both oropharynx and stomach. Three of the four exogenous lower respiratory tract infections were preceded by colonization of the nose.

Table II Intensive care acquired lower respiratory tract infection

\begin{tabular}{lccl} 
& $\begin{array}{l}\text { Group I } \\
(n=18)\end{array}$ & $\begin{array}{l}\text { Group II } \\
(\mathrm{n}=21)\end{array}$ & $\begin{array}{l}\text { Group III } \\
(\mathrm{n}=17)\end{array}$ \\
\hline Number of patients infected & 14 & 13 & 1 \\
Percentage of patients infected & $78 \%$ & $62 \%$ & $6 \%$ \\
$95 \%$ confidence intervals & $52-94 \%$ & $38-82 \%$ & $0-29 \%$ \\
Total number of infections* & 25 & 22 & 1 \\
Pneumonia & 5 & 5 & 0 \\
Purulent tracheobronchitis & 20 & 17 & 1 \\
Gram-positive infections & 2 & 3 & 0 \\
Gram-negative infections & 20 & 17 & 1 \\
Mixed infections & 2 & 1 & 0 \\
Yeast infections & 1 & 1 & 0 \\
Percentage preceded by colonizat ion & $92 \%$ & $91 \%$ & $0 \%$ \\
\hline
\end{tabular}

† $p<0.001$, difference between Group 1 \& II n.s. $(p=0.47)$, between Group I \& III $\mathrm{p}<0.0001$. between Group II \& Ill $p=0.0007$.

* Several patients acquired more than one lower respiratory tract infection. 
In group 111 , only one patient acquired a respiratory tract infection. This infection occurred on the 21 th day of mechanical ventilation and was not preceded by colonization of either oropharym $x$, stomach or nose.

Figure 2 depicts the cumulative percentage of patients that acquired lower respiratory tract infection. After ten days of mechanical ventilation, about $50 \%$ of the patients in both control groups had acquired infection.

\section{ICU-AGQUIRED LOWER RESPIRATORY TIRAGT INPECTION}

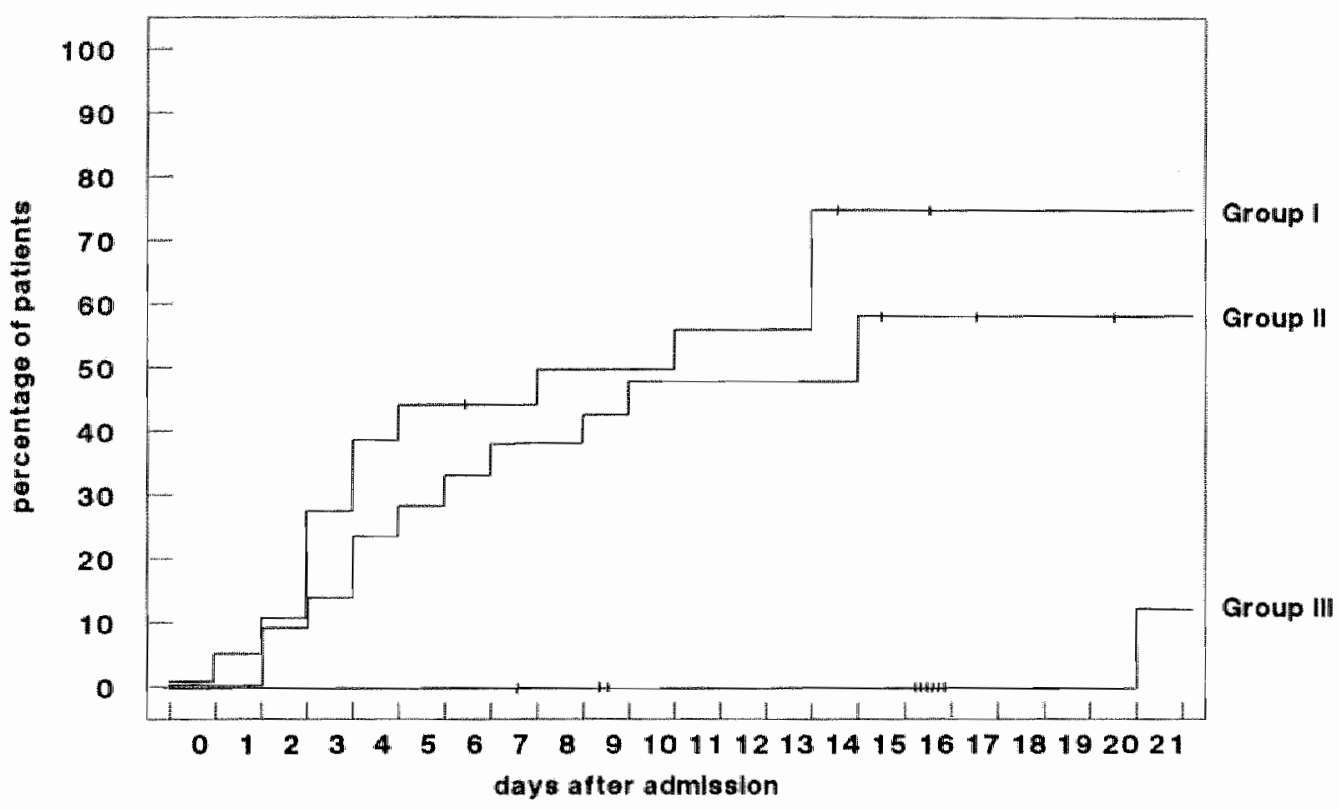

Figure 2 Cumulative percentage of patients acquiring lower respiratory tract infection during ICU-stay (Kaplan-Meier method).

Lower respiratory tract infections were predominantly caused by Gram-negative bacilli (table III). However, there was a difference between the etiology of early respiratory tract infection (occurring in the first five days after admission) and late respiratory tract infection. In early infection, Gram-positive cocci and Haemophilus influenzae played an important role, whereas in late infection Gram-negative bacilli prevailed, causing $74 \%$ of the infections (fig. 3 ).

Of all cases of lower respiratory tract infection, ten (five in group I and five in group II) were associated with definite radiologic signs of pulmonary infiltration, the others being cases of purulent tracheobronchitis. 


\begin{tabular}{|c|c|c|c|}
\hline & Group I & Group II & Group III \\
\hline Gram-negative bacilli & 22 & 14 & 1 \\
\hline Acinetobacter sp. & 2 & 1 & - \\
\hline Citrobacter sp. & 3 & - & - \\
\hline Enterobacter sp. & 3 & 1 & - \\
\hline Escherichia coli & 4 & 1 & - \\
\hline Klebsiella sp. & 3 & 1 & - \\
\hline Morganella morganii & 1 & 2 & - \\
\hline Proteus mirabilis & 2 & - & - \\
\hline Pseudomonas aeruginosa & 4 & 6 & - \\
\hline Pseudomonas maltophilia & - & 2 & - \\
\hline Serratia marcescens & - & - & 1 \\
\hline Gram-prositive bacteria & 4 & 6 & 0 \\
\hline Enterococci & 2 & 2 & - \\
\hline Staphylococcus anteus & 1 & 3 & - \\
\hline Streptococcus preumoniae & - & 1 & - \\
\hline Other Streptococei & 1 & - & - \\
\hline \multicolumn{4}{|l|}{ Other Gram-negative bacteria } \\
\hline Haemophilus influenzae & 3 & 5 & - \\
\hline \multicolumn{4}{|l|}{ Yeasts } \\
\hline Candida albicans & 1 & 1 & - \\
\hline Total* & 30 & 26 & 1 \\
\hline
\end{tabular}

* Several infections in Group 1 \& $\| 1$ were caused by more than one species of microorganisms.

\section{Infections at other sites}

The frequency of urinary tract infection in the three groups did not differ significantly (Table IV). Septicaemia and wound infection hardly occurred in group III. Lower respiratory tract infection was the source of septicaemia in four cases (two in group I and two in group II). The infections at other sites included five cases of pleural empyema (three in group I and two in group II) which were all preceded by lower respiratory tract infection with the same microorganism.

\section{Mortaliry}

In group I, four patients $(22 \%)$ died, in two cases $(11 \%)$ death could be attributed 


\begin{tabular}{|c|c|c|c|}
\hline & $\begin{array}{l}\text { Giroup } 1 \\
(n=18)\end{array}$ & $\begin{array}{l}\text { Croup II } \\
(n=21)\end{array}$ & $\begin{array}{l}\text { Group III } \\
(n=17)\end{array}$ \\
\hline Patients acquiring urimatry tract infection & $6(33 \%)$ & $8(38 \%)$ & $6(35 \%)$ \\
\hline Number of infections: & 8 & 10 & 6 \\
\hline \multicolumn{4}{|l|}{ Microorganisms involved: } \\
\hline Gram-positive & $3(38 \%)$ & $4(40 \%)$ & $4(67 \%)$ \\
\hline Gram-negative & $4(50 \%)$ & $4(40 \%)$ & $2(33 \%)$ \\
\hline Yeasts & $1(1.3 \%)$ & $2(20 \%)$ & - \\
\hline Paticnts acquiring septictemiat & $5(28 \%)$ & $8(38 \%)$ & $\mathbb{1}(6 \%)$ \\
\hline Number of infections ${ }^{*}$ & 7 & 9 & 1 \\
\hline \multicolumn{4}{|l|}{ Microorganisms involved: } \\
\hline Gram positive & $4(57 \%)$ & $6(67 \%)$ & - \\
\hline Gram-negative & $3(43 \%)$ & $\|(11 \%)$ & 1 \\
\hline Mixed Gram-positive/negative & - & $1(11 \%)$ & - \\
\hline Yeasts & - & $\|(11 \%)$ & - \\
\hline Pattiemts acquiring wound infection't & $2(11 \%)$ & $5(24 \%)$ & 0 \\
\hline \multicolumn{4}{|l|}{ Microorganisms involved: } \\
\hline Gram-positive & 1 & 1 & - \\
\hline Gram-negative & 1 & 3 & - \\
\hline Yeasts & - & 1 & - \\
\hline Patients acquiring other infections & $7(39 \%)$ & $7(33 \%)$ & $3(18 \%)$ \\
\hline \multicolumn{4}{|l|}{ Microorganisms involved: } \\
\hline Gram-positive & 3 & 2 & 3 \\
\hline Gram-negative & 4 & 5 & - \\
\hline
\end{tabular}

* No significant differences.

* Some patients acquired more than one infection at the same site.

to ICU-acquired lower respiratory tract infection. The two deaths $(10 \%)$ in group II were not infection related. Of the two deaths ( $12 \%$ ) in group III, one was related to infection: a Herpes simplex viral pneumonia. The mortality was too low to permit conclusions.

\section{Antibiotic use}

The reduction of the respiratory tract infection rate in group III resulted in a reduction of the use of systemic antibiotic therapy in this group. The number of patients requiring antibiotic therapy was $17(94 \%)$ in group I, $21(\rrbracket 00 \%)$ in group II, but 


\section{$(\ln \theta 5140)$}

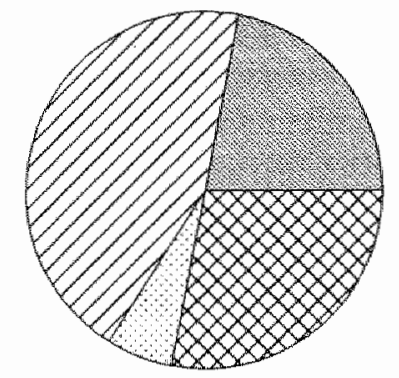

gram-posittve cocel $22 \%$

gram-negative cocel $44 \%$

yeasts $6 \%$

H. Influenzae $28 \%$
LATE INIFECTIONS

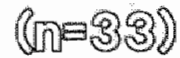

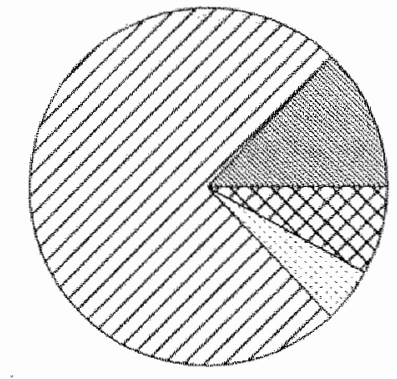

gram-positive coccl 13\%

gram-negative cocel $74 \%$

yeasts $5 \%$

H. Influenzae $8 \%$

Figure 3 Microorganisms isolated in early and late lower respiratory tract infection in patients from both control groups.

only $11(65 \%)$ in group III. The mean number of antibiotic days per patient (one antibiotic day is the use of one antibiotic during one day) in group III was 13 (excluding five days of cefotaxime prophylaxis/patient). This is lower than in group I (mean 42 days) or in group II (mean 26 days) $(p=0.001)$.

It should be stressed that antibiotic therapy was instituted by the responsible physicians in the ICU. The infection criteria they used were not al ways strictly the same as those employed in this study. Therefore, the use of antibiotics does not necessarily reflect the incidence of infection. However, it gives an impression of how the different antibiotic policies influenced the prescription of antibiotics by the physicians in the ICU.

For more detailed information on the antibiotic therapy see chapter IV.

\section{Discussion}

Although all but one patient in group I were treated with antibiotics lowering MCR, and mostly from an early stage, this did not result in a higher incidence of colonization and infection in group I than in group II in which the patients did not recieve therapy affecting MCR. It is probable that, in these critically ill patients, 
colonization resistance is already so severely impaired by reduction of the PCR that disturbance of the MCR does not result in a further increase of the colonization and infection rate. However, whereas PCR is quickly restored when the patient is extubated and regains consciousness, disturbance of the MCR by antibiotic therapy persists, leaving the patient prone to an increased risk of superinfection [Van der Waaij, 1982]. Therefore the use of antibiotics that do not affect MCR still is to be preferred.

As in other studies [Kerver, 1987; Stoutenbeek, 1984], lower respiratory tract infections in the control groups were generally preceded by colonization of either oropharynx, stomach or both with the causative microorganism.

We defined early respiratory tract infection as infection occurring within the first five days after admission, because it appeared that all these infections were caused by bacteria that already colonized the upper respiratory tract on admission. Frequently, these bacteria have already gained access to the lower airways soon after the onset of acute disease, either by aspiration of oropharyngeal contents [Langer, 1987] or by intubation [Nair, 1986]. This explains the important role of Staphylococcus aureus, Streptococcus pneumoniae and Haemophilus influenzae. which colonize the oropharynx of about $50 \%$ of healthy individuals [Wilson, 1983; Sanderson, 1985], in the etiology of early respiratory tract infection. Because early respiratory tract infection is often already incubating on admission, it can not be prevented by SDD alone. Therefore SDD was combined with five days of systemic cefotaxime. At the present time, all authors that have used cefotaxime for this purpose, have administered dlaily doses of $4 \mathrm{~g}$ [Stoutenbeek, 1984; Kerver, 1988; Ledingham, 1988]. However, a lower dose of cefotaxime achieves serum and sputum levels exceeding the minimum inhibitory concentrations for Streptococcus pneumoniae, Haemophilus influenzae and most Gram-negative bacilli [Carmine, 1983]. We therefore lowered the cefotaxime dose to $500 \mathrm{mg}$ tid which, in combination with selective decontamination of oropharynx and stomach, successfully prevented early lower respiratory tract infection.

Alter the fifth day of mechanical ventilation, lower respiratory tract infection was frequently caused by ICU-acquired microorganisms. The great majority of these newly acquired microorganisms were Gram-negative bacilli. This has also been found by others [Johanson, 1972; Ruiz-Santana, 1987]. We confirmed the important role of oropharyngeal colonization in the pathogenesis of respiratory tract infection. Our results further underscore the importance of bacterial colonization of the stomach in the pathogenesis of lower respiratory tract infection: the stomach was the primary source of microorganisms in seven cases of lower respiratory tract infection and played a role in eleven other cases.

It should be stressed that not mechanical ventilation but intubation is the principal factor resulting in aspiration of oropharyngeal and gastric contents. The presence 
of an endotracheal or tracheostomy tube interferes with the normal clearing mechanisms of the trachea. Furthermore, the tube cuff does not protect against micro-aspiration: small quantities of oropharyngeal secretion frequently pass the cuff, especially if high volume cuffed tubes are used [Pavlin, 1975; Seegobin, 1986].

SDD (group III) virtually eliminated colonization of oropharynx and stomach. In absence of gastric retention, the application of antibiotics in the stomach has the additional advantage of eliminating potentially pathogenic microorganisms from the lower digestive tract, thereby eliminating a major source of oropharyngeal colonization [LeFrock, 1979] and of urinary tract infection [Daifuku, 1984]. Since most of our patients had impaired peristalsis, decontamination of the rectum from Gram-negative bacilli in patients in group III was not always rapidly achieved. This explains why, in contrast to the results of other studies [Stoutenbeek, 1984], SDD did not reduce the incidence of catheter-associated urinary tract infection: frequently, urinary tract infection had already developed before decontamination of the rectum was achieved. In case of impaired peristalsis, decontamination of the rectum - and thereby possibly the prevention of urinary tract infection - might be achieved with enema's containing the same antimicrobial agents as are administered via the nasogastric tube.

It may be difficult to distinguish microbial colonization of the lower respiratory tract of intubated patients from lower respiratory tract infection. "True" diagnosis would require histological confirmation which cannot be obtained during lile. Other reliable techniques like bronchoalveolair lavage [Chastre, 1988] or the use of a protected specimen brush [Fagon, 1988] are not yet routinely available.

For the diagnosis of lower respiratory tract infection we used criteria commonly applied to intubated patients [Caplan, 1981; Craven, 1986; Unertl, 1987]. However, most authors consider infiltrative changes on the chest X-ray mandatory for the diagnosis lower respiratory tract infection and consequent institution of antibiotic therapy. In our opinion purulent tracheobronchitis should also be treated because it represents a symptomatic infection and because it not infrequently develops into pneumonia [Unertl, 1987]. The high incidence of pneumonia-associated septicaemia and mortality in other studies [Caplan, 1979; Caplan, 1981] can partly be attributed to the postponement of antibiotic treatment until after the development of infiltrations on the chest $\mathrm{X}$-ray.

Mortality in this study is low. This is partly explained by the design of the study: the 'fact that only patients with a duration of mechanical ventilation exceeding four days were included eliminates early mortality. Even taking this into account, mortality in the control groups still seems low considering the thigh incidence of lower respiratory tract infection. This might in part be caused by the improved treatment of Gram-negative bacillary lower respiratory tract infection in the last years and by 
the prompt institution of antibiotic therapy. Furthermore, the mortality due to ICU-acquired lower respiratory tract infection has probably been overestimated. In a recent study a direct relationship between ICU-acquired pneumonia and increased mortality could not be established [Craven, 1986]. Of the $30 \%$ mortality related to nosocomial pneumonia in another study, only $7 \%$ could really be attributed to pneumonia [Leu, 1986]. Mortality following nosocomial pneumonia seems to be caused be underlying disease rather than by pneumonia itself.

This explains the low infection related mortality in our two control groups, which makes it difficult to show possible differences in infection related mortality between the groups. Therefore, the assessment of the regime used in this and other studies depends mainly upon bacteriological and morbidity data. These data suggest strongly that the application of SDD in association with a short course of antibiotic prophylaxis represents a substantial advance in the control of ICU-acquired lower respiratory tract infection.

\section{Conclusion}

SDD in combination with an initial short course of systemic cefotaxime proved to be safe and effective in the prevention of respiratory tract infection in patients requiring prolonged mechanical ventilation. Our newly developed regime of SDD is as effective as the PTA-regime, but is less expensive and is safer on theoretical grounds. Provided that facilities for detailed microbiological surveillance are available, a regime of SDD, in association with a short course of systemic antibiotic prophylaxis, should be applied from an early stage to all patients expected to require prolonged mechanical ventilation. In patients that are otherwise at risk for developing mechanical ventilation associated lower respiratory tract infection e.g. patients whose oropharynxes are already heavily colonized with Gram-negative bacilli on admission, the use of SDD should also be considered.

\section{References}

Caplan ES, Hoyt N, Adams Cowley R. Changing patterns of nosocomial infections in severely traumatized patients. Ann Surg 1979; 45: 204-10.

Caplan ES, Hoyt N. Infection surveillance and control in the severely traumatized patient. Am J Med $1981 ; 70: 638-40$.

Carmine AA, Brogden RN, Heel RC, Speigth TM, Avery GS. Cefotaxime: a review of its antibacterial activity, pharmacological properties and therapeutic use. Drugs 1983; 25: 223-89.

Chastre J, Fagon JY. Soler $\mathrm{P}$, et al. Diagnosis of nosocomial bacterial pneumonia in intubated patients undergoing ventilation: comparison of the usefuness of bronchoalveolar lavage and the protected specimen brush. Aun J Med 1988; 85: 499-506.

Craven DE, Kunches LM, Kilinsky V. Lichtenberg DA, Make BJ, McCabe WR. Risk factors for pneumonia and fatality in patients recieving continuous mechanical ventilation. Am Rev Resp Dis $1986 ; 133: 792-6$. 
Daifuku R, Stamm WE. Association of rectal and urethral collonization with urinary tract infection in patients with indwelling catheters. JAMA 1984; $252: 2028-30$

Fagon JY, Chastre J, Hance AJ, el al. Detection of nosocomial lung infection in ventilated patients Am Rev Respir Dis 1988; 138: 110-6.

Johanson WG, Pierce AK, Sanford JP. Thomas GD. Nosocomial respiratory infections with Grannegative bacilli: The significance of colonization of the respiratory tract. Ann Intern Med 1972:77: $701-6$.

Kerver AJH, Rommes JH, Mevissen-Verhage EAE, et al. Colonization and infection in surgical intensive care patients: a prospectiwe study. Intensive Care Med 1987, 13:347-51.

Kerver AJH, Rommes JH, Mevissen-Verhage EAE, et al. Prevention of colonization and infection in critically ill patients. Crit Care Med 1988; 16: 1087-93.

Langer M, Cigada M, Mandelli M, Mosconi P, Tognoni G. Early onset pneumonia: a multicenter study in intensive care units. Intensive Care Med 1987: 13:342-6.

Le Frock JL, Ellis CA, Weinstein L. The relation between aerobic fecal and oropharyngeal microtlora in hospitalized patients. Am J Med Sci 1979; 277: 275-80.

Ledingham IMcA, Alcock SR, Eastaway AT, McDonald JC, McKay IC, Ramsay G. Triple regimen of selective decontamination of the digestive tract, systemic cefotaxime, and microbiological surveillance for prevention of acquired infection in intensive care. Lancet 1988; i: $785-90$,

Leu HS, Kauser DL, Wenzell RP. Hospital-acquired pneumonia: attributable mortality and mobbidity [Abstract]. Program and abstracts of the 26th Interscience Conference on Antimicrobial Agents and Chemotherapy $1986 ; 306$.

Nair $\mathbb{P}$, Jani K, Sanderson PJ. Transfer of bacteria into the trachea during endotracheal intubation. I Hosp Infect 1986; 8:96-103.

Pavlin EG, Van Nimwegan D, Hormbein TF. Failure of a high-compliance low-pressure euff to prevent aspiration. Anesthesiology 1975:42:216-9.

Ruiz-Santana S, Jimenez AG, Esteban A, et al. ICU pneumonias; a multi-institutional study. Crit Care Med 1987; 15:930-2.

Sanderson PJ. The sources of pneumonia in ITU patients. Infect Contr 1986; 7: $104 w 6$.

Seegobin RD, Van Hasselt GL. Aspiration beyond endotracheal cuffs. Can Anuesth Soc J 1986; 33: 273-9.

Stoutenbeek ChP, Van Saene HKF, Miranda DR, Zandstra DF. The effect of selective decontamination of the digestive tract on colonization and infection rate in multiple trauma patients. Intensive Care Med 1984; 10: 185-92.

Unertl K. Ruckdeschel G, Selbmanm HK, et al. Prewention of colonization and respiratory infections in long-term ventilated patients by local antimicrobial prophylaxis. Intensive Care Med 1987: 13: $106-13$

Van der Waati D. Colonization resistance of the digestive tract: clinical consequences and implications. J Antimicrob Chemother 1982; 10:263-70.

Wilson GS. Miles AA. Parker MT. Topley and Wilson's principles of bateriology virollogy and immunity. Vol I General microbiology and immunity. 7th ed.London: Edward Amold Lid. 1983: $230-44$ 



\section{Selective decontamination and short-term systemic antibiotic prophylaxis in mechanically ventilated patients: cost-effectiveness analysis.}

\section{Introduction}

Intensive care acquired infection is a major problem in critically ill patients [Daschner, 1982; Donowitz, 1982]. Not only are intensive care acquired infections associated with a considerable increase in morbidity and mortality |Thorp, 1979|, they also result in increased costs due to prolonged hospital stay and extra diagnostic and therapeutic services [Haley, 1981]. Lower respiratory tract infection is one of the most frequently reported infections in ICU patients [Massarani, 1986], especially in those patients requiring prolonged mechanical ventilation $\|$ Cross, 1981]. Respiratory tract infection further is, logether with septicaema and wound infection, one of the infections associated with the greatest increase in cost [Haley, 1981]. The magnitude of the economic consequences of these infections stresses the need for continued preventive efforts.

We studied the efficacy of a novel regime of SDD in the prevention of respiratory tract infection in critically ill patients that were mechanically ventilated for at least five days (chapter V). In a prospective three group study the incidence of lower respiratory tract infection in a group of patients receiving SDD in combination with a short course of systemic cefotaxime (group III) was compared with Iwo groups of patients in which antibiotic therapy was instituted only on clinical cvidence of infection. In control group 1 our previous antibiotic policy was continued: on clinical evidence of infection patients were treated with antibiotics known to affect the anaerobic gastro-intestinal flora. In control group II, the use of antibiotics was restricted to those not influencing the anaerobic gastro-intestinal flora. The reason for the institution of two different control groups is provided elsewhere (chapter: III).

The clinical results of this study have been described in chapter $V$. It may be concluded that SDD, in association with a short course of cefotaxime, is effective in preventing lower respiratory tract infection in mechanically ventilated pationts. However, the decision whether or not to introduce this strategy as a routine approach, can only been taken after the medical results have been complementcd by an economic appraisal. 
The question addressed in this chapter is: which of the three strategies employed to prevent or to treat lower respiratory tract infections is the most efficient? This question will be answered by means of a cost-effectiveness analysis [Drummond, 19801, in which the hospital charges, and the costs of bacteriologic cultures and of antibiotic therapy in the three groups are prospectively compared.

\section{Methods}

The study design has been described in chapter III. The costs associated with infection and infection prevention were estimated as follows:

\section{Acquisition costs of antibiotics}

The acquisition costs of the usual daily dose of every antibiotic used were quantified. The costs of antibiotic therapy were estimated by multiplying these costs by the amount of days the patient used the antibiotic.

The acquisition costs of antibiotic therapy varied from DFI 8.64 per day (penicillin) to DFI 295.80 per day (vancomycin). *

\section{Costs of bacteriologic cultures}

Cultures of tracheal aspirate and urine were performed on admission. Thereafter urine was cultured once weekly and tracheal aspirate thrice weekly. Cultures from both sites were performed more often if necessary. Cultures from other sites (e.g. blood, wounds, drains etc.) were taken if this was indicated on clinical grounds. To evaluate the effect of SDD, surveillance cultures of oropharynx, stomach and rectum were performed twice weekly.

The cost of each culture was DFI 25.50, to which DFI 13.60 has to be added for each microorganism cultured, this being the cost of susceptibility testing.

\section{Cost of the regime}

The cost of the regime used for selective decontamination was DFI 25.64 per day. For the first five days DFI 46.74 per day has to be added, this being the cost of systemic cefotaxime. These are merely acquisition costs, the costs associated with the application of SDD and systemic antibiotic prophylaxis (e.g. nurses fees, disposable gloves etc.) were not taken into account.

\section{Other costs}

The costs of lower respiratory tract infection are not limited to those of antibiotics and of bacteriological cultures. Lower respiratory tract infection also results in an increased use of drugs other than antibiotics and in an increased use of disposa-

* One DFi is approximately US $\$ 0.50$ 
bles. Furthermore it might increase the need of laboratory tests, respiratory therapy etc., with consequent increased costs [De Clercq, 1983]. However, the design of our study does not permit the estimation of these costs. All these costs are included in the routine charges for hospitalization at the Intensive Care Unit, which were DFI 2,250.- per day or per part of a day (September 1987).

\section{Results}

\section{Study population}

From May 1986 to September 1987, 56 patients (18 in group 1, 21 in group 11 and 17 in group III) were included in the study. The three different groups were comparable with respect to age, sex and the severity of disease as determined by the APACHE II score [Knaus, 1985]. Duration of intubation and of ICU-stity were lowest in group III. However, these differences did not reach significance. For detailed information about the study population see chapter IV.

\section{Table I Intensive care acquired infections}

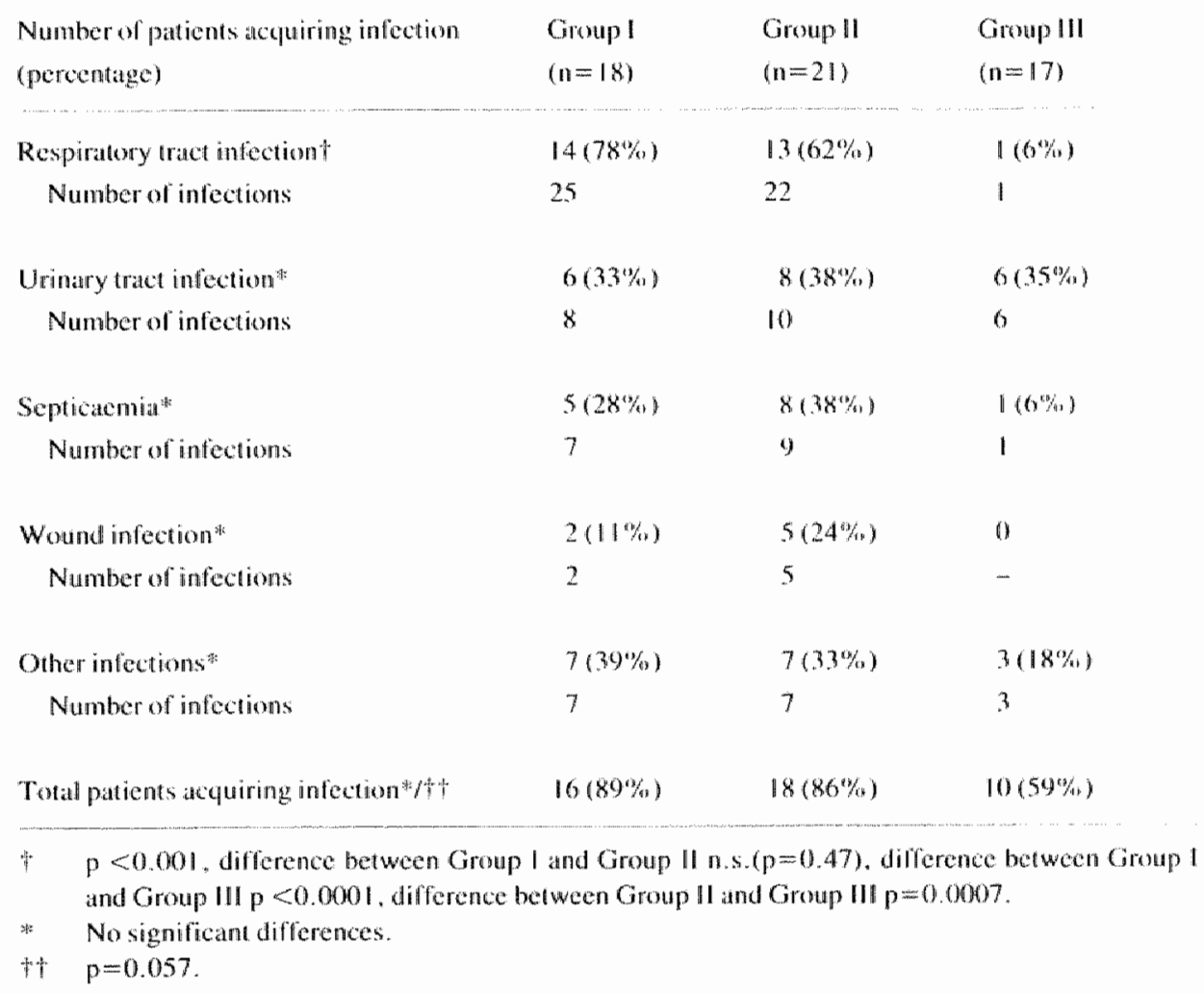




\section{Hections}

The differentiation of amtibiotics used in group I and group II did not result in a difference in the infection rate. SDD and short-term systemic cefotaxime in group III decreased the lower respiratory tract infection rate. The urinary tract infection rates in the three groups did not differ. Infections at other sites than the urinary and respiratory tract occurred in only three patients in group III (Table I)

\section{Costribof bateriological cultures.}

The lower incidence of lower respiratory tract infection in group III resulted in a slight reduction of the amount of cultures of tracheal aspirate and in a much lower percentage of positive cultures as compared to both group I and group II. Consequently, the need for susceptibility testing in group III decreased and the costs of routinely performed bacteriological cultures in group III were lower than those in both other groups (Table II).

In group III patients, surveillance cultures of oropharyngeal secretion, gastric contents and rectum were performed twice weekly 10 monitor the effect of SDD. The mean costs of these cultures were DFI 857. - per patient. The costs of surveillance cultures in patients in both control groups were not taken into account because the performance of surveillance cultures in these patients only served study purposes.

\section{Table II Bacteriological Culares}

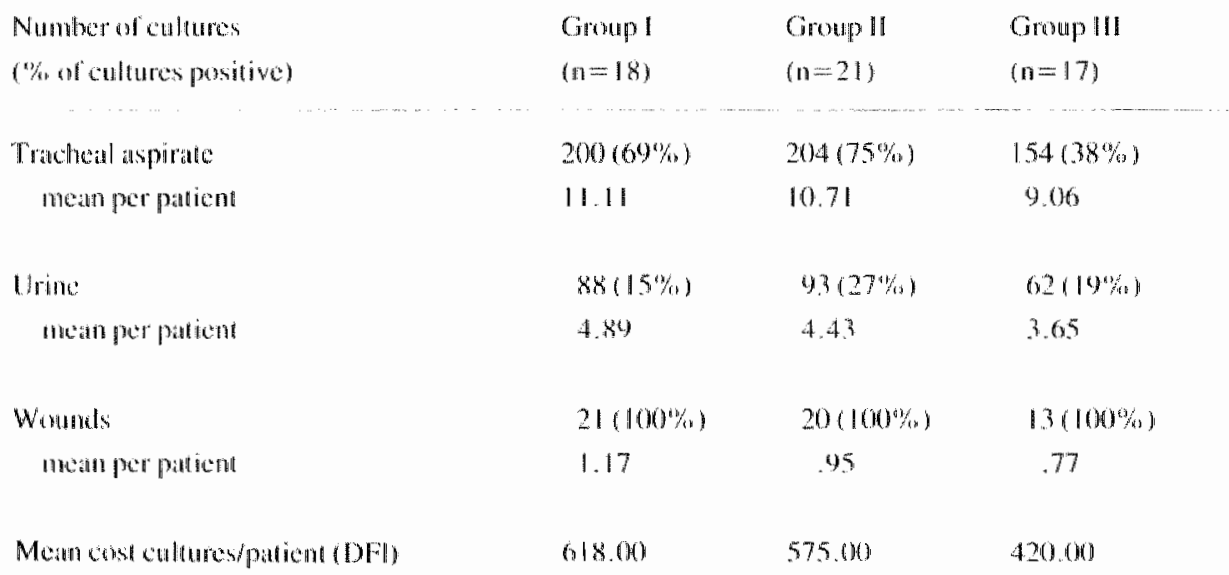

Acquisition costs of antibiotics

In group I and group II, virtually all patients received antibiotic therapy (Table

III). The number of antibiotic courses prescribed was highest in group I and so were the costs of antibiotic therapy. Although there was no significant difference 
in the infection rate between group I and II, the number of antibiotic courses per patient prescribed in group II was lower than in group I. The percentage of patients receiving antibiotic therapy and the number of antibiotic courses per patient was lowest in group III. Consequently, the costs of antibiotic therapy in group III were lower than in both other groups. Even if the costs of SDD and systemic cefotaxime in group III are added, the total antibiotic costs per patient in this group are still lower than in both control groups (Table III).

Table III Acquisition costs of antibiotic therapy

$\begin{array}{lll}\text { Group }) & \text { Group } 11 & \text { Group } 111 \\ (n=18) & (n=2) & (n=17)\end{array}$

Patients receiving therapeutic

antibiotics (percentage)

$17(94 \%)$

$21(100 \%)$

$11(65 \%)$

Antibianic courses/pantent?

5.2

3.2

$1.5(2.5)^{*}$

Antibiotic danys/patient

42

Costs of antibiontic therapytt

4.022

26

$13(18)^{* 4}$

Cosis SDD and systemic celotuxime

$-$

1.840

901

855

Total antibiotic costs/patient (DFI)

4,022

1,840

1,758

* The numbers in parentheses include systemic cefotaxime prophylaxis.

+ Overall $p=0.0001$. Diflerence between Group I \& II $p=0.046$, between Group I \& III $p=0$ 0.0002. between Group 11 \& $111 \mathrm{p}=0.0007$.

th Overall $p=0.0015$. Difference between Group I \& II n.s. $(p=0.15)$, between Group I \& III $p=0.00 \| 6$, between Group II\& III $p=0.0052$.

Overall costs

Table IV gives an overview of the mean costs of antibiotic therapy and of bacteriologic cultures in patients in each group. For group III, the mean costs of the regime of selective decontamination and systemic cefotaxime are added, as are the costs of surveillance cultures.

The routine hospital charges accounted for the major part of the costs. These charges were lowest in group III, in which the average ICU-stay was shortest. However, the difference in duration of ICU-stay, and consequently the difference in hospital charges, was not significant. In table IV, the hospital charges are, therefore, mentioned separately. 
Table IV Meanoverall cosss per patient

\begin{tabular}{|c|c|c|c|}
\hline Costs in DFl (range) & Group I & Group II & Group III \\
\hline Antibiotic therapy & $\begin{array}{l}4,022 \\
(0.11 .586)\end{array}$ & $\begin{array}{l}1.840 \\
(170-3,993)\end{array}$ & $\begin{array}{l}901 \\
(0-3,597)\end{array}$ \\
\hline SDD and systemic ceforaxime & - & - & $857(439-1.772)$ \\
\hline All antibrofics & $\begin{array}{l}4,022 \\
(0-11.586)\end{array}$ & $\begin{array}{l}1.840 \\
(170 \times 3.993)\end{array}$ & $\begin{array}{l}1,758 \\
(439-4,702)\end{array}$ \\
\hline Bacteriological cultures & $\begin{array}{l}618 \\
(180-1,224)\end{array}$ & $\begin{array}{l}575 \\
(153-1,074)\end{array}$ & $\begin{array}{l}420 \\
(153-859)\end{array}$ \\
\hline Surveillance cultures & - & - & $857(260-2.251)$ \\
\hline Totall & $\begin{array}{l}4641 \\
(265-12,679)\end{array}$ & $\begin{array}{l}2415 \\
(455-4.703)\end{array}$ & $\begin{array}{l}3036 \\
(866-7,194)\end{array}$ \\
\hline Hospital charges & $\begin{array}{l}70,625 \\
(20,250-180,000)\end{array}$ & $\begin{array}{l}58,393 \\
(22,500-1 / 4,750)\end{array}$ & $\begin{array}{l}54,662 \\
(18,000-135,000)\end{array}$ \\
\hline
\end{tabular}

\section{Discussion}

Selective decontamination (consisting of topically applied polymyxin $\mathrm{E}$, tobramycin, and amphotericin B), in combination with short-term systemic antibiotic (cefotaxime) prophylaxis, prevents colonization of oropharynx and stomach with potentially pathogenic microorganisms and reduces the incidence of lower respiratory tract infection in patients receiving prolonged mechanical ventilation [Stoutenbeek, 1984; Kerver, 1988; Ledingham, 1988]. We prospectively proved that a novel regime -using norfloxacin as the principal agent for SDD- in associathon with a lower dose of cefotaxime is equally elfective (chapter $V$ ).

The present chapter offers a comparison of the financial costs of infection and infection prevention, which can easily be measured. However, an economic appraisal should not only take financial aspects into account, but also the fact that the aim of ICU treatment -to change the course of the patients disease for the better so that the patient is able to leave the ICU alive, in the best possible condition and in the shortest amount of time- was best met in group III.

\section{Financial costs}

\section{Antibiotic therapy}

In group I we more or less adhered to the previous antibiotic policy on our ward. In group II the use of antibiotics was restricted to those antibiotics not disturbing 
the anaerobic gastro-intestinal flora. The incidence of infection in both control groups did not differ significantly. However, the number of antibiotic courses prescribed per patient in group I was higher, as were the costs of antibiotic therapy. Although, due to the great spread of the antibiotic costs between patients within the same group, this last difference is not statistically significant, it is in agreement with the results of a recent study, in which the introduction of antibiotic formulary restrictions as such considerably reduced total antibiotic use, as well as the costs of antibiotic therapy [Woodward, 1987]. The reduction of the average costs of antibiotic therapy in group III as compared to both other groups can be attributed to the reduction of the respiratory tract infection rate. The reduction of the costs of antibiotic therapy more than outweighed the costs of the antibiotics that were used for SDD and systemic prophylaxis.

\section{Bacteriological cultures}

The overall costs of routinely performed bacteriological cultures in group III were lower than in both control groups. The decreased risk of lower respiratory tract infection might enable us to decrease the frequency of cultures of the tracheal aspirate from three times weekly to twice weekly, with consequent further reduction of the costs. This would have saved about two cultures of tracheal aspirate per patient, which, with an average cost of DFI 40 per culture, would result in a further reduction of the costs of about DFI 80 per patient.

SDD necessitates the introduction of surveillance cultures of oropharynx, stomach and rectum. These cultures are indispensable to monitor the effect of SDD and the possible development of resistance against the antibiotics used [Schimpff, 1981]. Since we did not observe the emergence of resistance against the antibiotics used for SDD, we consider it safe to perform surveillance cultures only once weekly in the future. This would reduce the costs of surveillance cultures to approximately half, estimated savings about DFI 400 per patient.

\section{Additional costs}

One should be aware that the costs of infection are not limited only to those of antibiotics and bacteriological cultures. Infection might also increase the need for other ancillary services such as chest $X$-rays, laboratory tests, respiratory therapy etc., and increase the use of drugs other than antibiotics and the use of disposable material [De Clercq, 1983]. Inversely, a reduction of the infection rate may result in a reduction of these costs. The reduction of the lower respiratory tract infection rate induced by the introduction of SDD might, for example, enable us, after about the fourth day of admission, to reduce the frequency of chest $X$-rays from once daily (costs DFl 53/day) to thrice weekly (average costs DFl 23/day). With a mean duration of stay 23 days, this would have saved DFI 570 per patient.

The three modifications suggested above, would have reduced the average costs of treatment in group III by DFI 1050 to DFI 1986 per patient, the lowest of all groups. 
Overall costs

Although the differences in duration of stay and consequent hospital charges fell short of statistical significance, we feel that these differences deserve consideration in the overall analysis: ICU-acquired respiratory tract infection thas often been shown to prolong $\mathbb{1 C U}$ and hosptall stay significantly $[$ Haley, 1980; Haley, 1981; De Clercq, 1983; Craig, 1984J and the lack of significance in our study seems to be due to the great spread in the duration of ICU-stay.

\section{Beneficial effects of SDD}

Reduction of the lower respiratory tract infection rate has beneficial effects on the heallh of patients which include the following:

(1) Decrease of infection-associated mortality.

In our - relatively small - study population infection related mortality was too low to permit any conclusions. However, Ledingham et al reported that the use of the PTA-regime in combination with a short course of systemic cefotaxime was associated with a reduction in mortality in patients staying at the ICU for seven days or more [Ledingham, 1988].

(2) Reduction in the use of toxic antibiotics.

The use of aminoglycosides, well known for their nephrotoxicity and ototoxicity [Schentag, 1982; Eisenberg, 1987] was required in 16 patients in group $(89 \%), 12$ patients in group II $(57 \%)$, but only in four of the patients receiving $\mathrm{SDD}(24 \%)$.

(3) Decrease of the incidence of residual symptoms.

Our knowledge about the harmful long-term effects of lower respiratory tract infection is still unsatisfactory. Lower respiratory tract infection might result in residual symptoms in the form of recurrent respiratory tract infection $\mid$ Fry. $1960 \mid$, in the loss of functioning lung tissue, or occasionally even the loss of a complete lung.

Until present, there have been no negative effects reported on the use of SDD in mechanically ventilated patients, even though this technique has now been used for more than two-and-a-hall years at one ICU [Stoutenbeek, 1987].

\section{Conclusion}

SDD, in combination with initial systemic antibiotic prophylaxis, prevents colonization of oropharynx and stomach with potentially pathogenic microorganisms and reduces the incidence of lower respiratory tract infection in mechanically ventulated pattients IStoutenbeek, 1984; Kerver, 1988; Ledingham, 19881. However, the PTA-regime, in combination with high dose cefotaxime, is about four 
times as expensive as the regime we have described Vollatrd, 19841. A cost. effectiveness analysis of the PTA-regime has never been performed. Although our analysis does not take into account all costs associated with lower respiratory tract infection or with the administration of SDD, we conclude that the regime studied is cost-effective in that it has great clinical benefits over the conventional antibiotic policy for no -or only a tew-extra costs [Doubilet. 1986].

The use of the regime of SDD consisting of nofloxacin, polymyxin E and amphotericin $B$ in combination with a short course of systemic. low dose, cefolaxime should be considered in every ICU for patients expected to require prolonged mechanical ventilation.

\section{References}

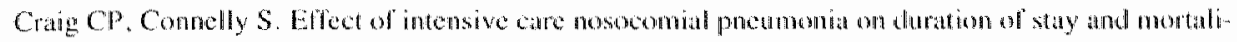
1y. Am J Infect Contr 1984: 12:233-8.

Cross AS, Roup B. Role of respiratory assistance devices in endemic nusocomial pheumoniat. An J Med 1980:70:681-5.

Dasseher FD. Frey P. Woflf G, Batamann PC, Suter P. Nosoconnial infections in intensive cane wards: a malcicenter prospective study. Intensive Cire Med 1982:8:5-9.

De Clereq H, De Decker GH. Alexander JP. Huyghens L. Cost evaluation of infections in intensive calre. Acta Anacsthesiologica Belgical 1988: 34:179-90.

Donowitz LG, Wenzel RP. Hoyt JW. High risk of hopital atequired inlection in the ICU pationt Crit Care Med 1982:10:355-7.

Doubilet P. Weinstein MC, McNeil BJ. Use and misuse of the temn "cost ellective" in medicine. N Engl J Med 1986: 314:253-6.

Drummond MF. Principles of economic appratsal in health care. 1 th ed. Oxlord: Oxlord medical publi. cations, $1980: 14$.

Eisenberg JM. Koffer H, Glick HA, et al. What is the cost of nephrotoxicity associated with antinoglycosides? Ann Int Med 1987; 107; 900-9.

Fry J. Fate of 424 patients with pneumonia and bronchitis. Brit Med J 1960; ii: $148.3-6$.

Halley RW, Schaberg DR, Von Allmen SD, McGowan JE. Estimating the extrat charges and profongation of hospiatization due to messocomial infections: a comparison of methods. J Infect Dis 1980: 14: $248-57$.

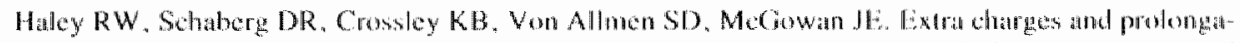

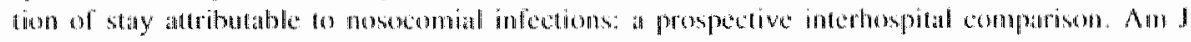
Med $1981: 70: 51-38$.

Kerwer AJH, Rommes JH. Meviswen-Verhage EAE, et all. Prevention of collunization and infection in writically ill patientw. Crit Care Med 1988; 16: 1087-93.

Knats WA. Draper EA. Wagner DP. Zimmerman IF. Apache II: A severity of discase clabsilicalion system. Crit Care Med 1985: 13:818-29.

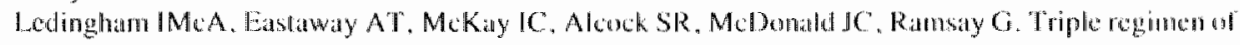
relective decontamination of the digestive tract, systemic cefolaxime. and microbiological aurveitlance for prevention of acquired intectom in intensive care. Lanced 1988; $1: 785 \% 90$.

Massartani RM. Hichulyer WJ. The intensive care unit. In. Bennet JW, Brachman PS, cas. Hospital infections. Boston: Litule, Brown and company, 1986:285.97.

Schentag 11, Cerril FB, Plaut ME. Clinicall and pharmacokinetic characteristics of aminoglycoside mephotoxicity in 201 aritically ill pattens. Antimicrob Agents Chemother 1082, $21,721.6$.

Schimpfe SC. Surveillance cultures. J Infect Dis 1981; $144: 81.4$.

Stoutenbeek ChP. Van Satene HKF, Miranda DR, Zathdstrat DF. The eflect of selective decontamimation of the digestive fract on colonization and infection rate in multiple tratumatients. Intensive Cate Med 1984: 10: 185-92. 
Sloutenbeck CP. Van Sacne HKF. Zandstra DF. The effect of nonabsorbable anibiotics on the emergence of resistant bacteria in patiens in an intensive anit. J Antimicrob Chemother 1987: 19:513 20.

Thorp JM. Richards WC. Telfer ABM. A survey of infection in an intensiwe care unit. Anaesiltesia $1079: 34: 643-50$.

Vollatard EJ, Muller NF, Baggerman C. Is SDD betadibat? Een farmaceutische benatdering. Ziekerehuishygience on Intehticpreventic 1984; 3:41-2.

Woodward RS. Medoff G. Smith MD. Gray IL. Antibiotic cosi sawings from formulary restrictions atndl physician monitoring in a medicato-school-affiliated hospital. Am J Med 1987; 83; 817-23. 


\section{Summary and general discussion}

\section{Introduction}

Lower respiratory tract infection is a major problem in mechanically ventilated patients. In patients requiring prolonged mechanical ventilation the incidence of respiratory tract infection may be as high as 60 percent, resulting in a considerable increase of morbidity, of the length and costs of hospitalization and probably also of mortality.

Colonization of the oropharynx and of the stomach with potentially pathogenic microorganisms plays a key role in the development of lower respiratory tract infection (chapter II):

-Early lower respiratory tract infection (occurring in the first five days after admission) is frequently caused by oropharyngeal commensal microorganisms (Hacmophilus influenzae. Streptococcus pneumoniae and Staphylococcus aureus), that reach the lower airways by aspiration at the onset of acute disease or at intubation. -Soon after the onset of disease, colonization of the oropharynx and of the stomach with high concentrations of Gram-negative bacilli occurs in almost all critically ill patients. Aspiration of oropharyngeal and gastric contents around the cuff of the endotracheal tube, which frequently takes place, spreads Gram-negative bacilli into the lower respiratory tract, where infection may result.

Since oropharyngeal and gastric contents are the principal source of microorganisms causing lower respiratory tract infection, a reasonable strategy of infection prevention would be the elimination of potentially pathogenic microorganisms from these sites.

Selective decontamination of the digestive tract is a novel method of infection prevention. It aims at the elimination of potentially pathogenic microorganisms from the digestive tract, at the same time leaving the autochthonous anaerobic flora intact. Parts of this anaerobic flora protect against colonization of the digestive tract with Gram-negative bacilli. This protective effect is called microbial colonization resistance (chapter I).

Selective decontamination has proved to be effective in the prevention of infections in neutropenic patients. The first studies in mechanically ventilated patients also showed a beneficial effect of selective decontamination on the infection rate. However, these first studies were not prospectively controlled; the infection rates were compared with those in historical control groups. Moreover, the regime of selective decontamination used in these studies contained tobramycin, which car- 
ries the risk of disturbance of microbial colonization resistance, as well as -especially in patients with impaired renal function- a small risk of toxicity by tobramycin resorption.

\section{Study design}

Our study provides a prospective, controlled assessment of the effect of a novel regime of selective decontamination on the lower respiratory tract infection rate in patients receiving prolonged (at least five days) mechanical ventilation.

On admission patients were randomly allocated to one of three groups. Patients in both control groups I $(n=18)$ and II $(n=2))$ did not receive antibiotic prophylaxis, antibiotics were administered only on clinical evidence of infection. In group I infections were treated with antibiotics known to disturb the microbial colonization resistance, whereas in group II the use of antibiotics was restricted to those that are known not to have such effect. The aim of this part of the study was to determine the influence of antibiotics from these different categories on the colorization and infection rate.

Patients in group III $(n=17)$ received a regime of selective decontamination from admission until extubation, in conjunction with a short course of systemic cefotaxime. Selective decontamination consisted of norfloxacin $50 \mathrm{mg}$, polymyx in E 200 $\mathrm{mg}$ and amphotericin B $500 \mathrm{mg}$, administered four times daily via the gastric tube. A sticky paste containing $2 \%$ concentrations of the same agents was applied to the buccal mucosa four times daily. Intravenous cefotaxime $(500 \mathrm{mg})$ was administered to patients in group III eight hourly during the first five days of admission.

\section{Results}

On admission the oropharynx was frequently colonized with commensal microorganisms and, less often, with Gram-negative bacilli. In both control groups this colonization persisted and often resulted in early lower respiratory tract infection. In group III all oropharyngeal commensals and Gram-negative bacilli were eradicated from the upper and lower respiratory tract and early lower respiratory tract infection was completely prevented.

Patients in both control groups frequently acquired new microorganisms - predominantly Gram-negative bacilli - in oropharynx and stomach. Eighty-three percent of the patients in group I and $90 \%$ of the patients in group $I I$ acquired at least one new species of microorganisms in their oropharynx during admission. New colonizations of the stomach occurred in $94 \%$ of the patients in group I and in $90 \%$ of the pattients in group II. In group III selective decontamination virtually prevented the acquisition of new microorganisms at both sites (chapter IV).

The administration of antibiotics that disturb the microbial colonization resistance 
(group I) caused a significant increase of the concentration of Gram-negative bacilli in oropharynx and stomach, whereas antibiotic therapy in group II did not affect the oropharyngeal or gastric concentration of Gram-negative bacilli. Although an increase in the oropharyngeal and gastric concentration of microorganisms increases the risk of lower respiratory tract infection, there was no significant difference in the respiratory tract infection rate between group I and group II. In group $I, 14$ patients $(78 \%)$ together acquired 25 lower respiratory tract infections, versus 13 patients $(62 \%)$ who acquired 22 infections in group II $(p=0.47)$. In both control groups, colonization of oropharynx and stomach played a pivotal role in the pathogenesis of lower respiratory tract infection: over $90 \%$ of the respiratory tract infections in these groups were preceded by colonization of orophar$y \mathrm{nx}$, stomach or both with the causative microorganism.

In the group of patients receiving selective decontamination and systemic cefotaxime, the incidence of lower respiratory tract infection was significantly lower than in both control groups: only one patient $(6 \%)$ in group 111 acquired lower respiratory tract infection $(p<0.001)$. This infection was not preceded by oropharyngeal or gastric colonization with the causative microorganism (chapter V).

Most lower respiratory tract infections in both groups were caused by Gram-negative bacilli. However, in the etiology of early respiratory tract infection the commensal flora of the oropharynx (Streptococcus pneumoniae, Staphylococcus aureus and especially Haemophilus influenzae) also played an important role.

The regime of selective decontamination and systemic antimicrobial prophylaxis used in this study decreased the costs of antibiotic therapy to such an extent that it more than outweighed the costs of the regime. Although the costs of routinely performed cultures were lowest in group III, the total costs of bacteriological investigations in this group were higher than in both other groups. This was entirely due to the costs of the surveillance cultures of oropharynx, stomach and rectum, which are necessary to monitor the effect of selective decontamination. Despite this, we found the application of our regime of selective decontamination in mechanically ventilated patients cost-effective in that it provides great benefits without - or with only few - extra costs (chapter VI).

\section{Discussion}

The use of antibiotics that disturb the autochthonous anaerobic flora and thus the microbial colonization resistance, increases the concentrations of Gram-negative bacilli in the oropharynx and in the stomach of critically ill patients. This increases the risk of lower respiratory tract infection. However, elimination of this risk (group II) only slightly reduced the incidence of lower respiratory tract infection. This might be explained by the fact that, in these critically ill patients, the physio- 
logical colonization resistance (swallowing, salivation, coughing, etc.) also is severely reduced, by disease itself as well as by endotracheal intubation and other medical interventions. In moderately ill patients the restriction of the use of antibiotics to those that do not affect the autochthonous anaerobic flora might be sufficient to prevent colonization and infection with Gram-negative bacilli. In mechanically ventilated patients it certainly is not, which necessitates the addition of other prophylactic measures.

Selective decontamination of the oropharynx and of the lower digestive tract (in combination with short-term systemic cefotaxime) was very effective both in eradicating already existing colonization and in preventing new colonization of the oropharynx and of the stomach of mechanically ventilated patients. Elimination of these major sources of microorganisms causing lower respiratory tract infection resulted in a highly significant decrease of the incidence of unit-acquired respiratory tract infection.

The addition of shori-term antibiotic prophylaxis to the regime for the first days after intubation is necessary because, at admission at the ICU, oropharyngeal microorganisms often have already gained access to the lower respiratory tract where they can not be reached by antibiotics that are topically applied to the higher airways.

An additional advantage of selective decontamination is that, if bowel movements are not impaired, the antibiotics applied to the stomach also decontaminate the lower digestive tract and the faeces. This eliminates a major source of endogenous infection, of endotoxaemia and of cross-infection. Furthermore, the elimination of Gram-negative bacilli from oropharynx and lower digestive tract eliminates two major sites of development of resistance to antibiotics.

\section{Conclusions}

The use of antibiotics which disturb the autochthonous anaerobic flora of oropharynx and lower digestive tract, gives rise to an increase in concentrations of Gramnegative bacilli in stomach and oropharynx of critically ill patients. The use of these antibiotics in hospitalized patients should be avoided if possible.

Selective decontamination with norfloxacin, polymyxin $\mathrm{E}$ and amphotericin B in combination with short-term systemic cefotaxime proved to be an effective, safe and cost-efficient strategy for the prevention of respiratory tract infection in mechanically ventilated patients. A regime of selective decontamination in association with an initial course of systemic antibiotic prophylaxis should be applied from an early stage in all patients requiring prolonged mechanical ventilation. 


\section{Samenvatting en discussie}

\section{Inleiding}

Infecties van de lagere luchtwegen vormen een groot probleem bij kunstmatig beademde patiënten. Bij patiënten die gedurende langere tijd moeten worden beademd, stijgt de incidentie van deze infecties tot boven de 60 procent. Lagere luchtweginfecties resulteren in een stijging van de morbiditeit, van opnameduur en -kosten en waarschijnlijk ook van de mortaliteit.

Kolonisatie van de oropharynx en van de maaginhoud met potenticel pathogene micro-organismen spelen een sleutelrol in de pathogenese van infecties van de lagere luchtwegen (Hoofdstuk II).

Voor zover infecties ontstaan gedurende de eerste dagen na opname, worden zij meestal veroorzaakt door micro-organismen die als commensaal in de oropharynx vóorkomen, te weten: Haemophilus influenzae, Streptococcus pneumoniae en Staphylococcus aureus. Deze micro-organismen bereiken de lagere luchtwegen door aspiratie, optredend tijdens of kort na het ontstaan van ziekte of trauma, of tijdens het intuberen.

Bij ernstig zieke patiënten raken oropharynx en maaginhoud meestal snel gekoloniseerd met Gram-negatieve bacillen, dikwijls in hoge concentraties. Door aspiratie van maag- en keelinhoud langs de manchet van de endotracheale tube -hetgeen frequent voorkomt- bereiken deze Gram-negatieve bacillen de lagere luchtwegen, waar zich vervolgens een infectie kan ontwikkelen.

Oropharynx en maag zijn dus de belangrijkste bronnen van verwekkers van lagere luchtweginfecties bij beademde patienten. Het ligt voor de hand te veronderstellen dat eliminatie van potentieel pathogene micro-organismen uit oropharynx en maag zal leiden tot een reductie van het aantal infecties van de lagere luchtwegen.

Selectieve decontaminatie van de tractus digestivus is een nieuwe methode van infectiepreventie, waarbij wordt gestreefd naar de eliminatie van (aerobe) potentieel pathogene micro-organismen uit de tractus digestivus. De anaerobe intestinale flora wordt hierbij intact gelaten. Deze anaerobe flora (of althans een deel daarvan) speelt een belangrijke rol bij de bescherming van de tractus digestivus tegen kolonisatie met Gram-negatieve bacillen. Dit beschermend effect wordt microbiële kolonisatieweerstand genoemd (Hoofdstuk II). 
Bij neutropenische patiënten bleek de toepassing van selectieve decontaminatie te resulteren in een sterke reductie van het aantal infecties. Ook de eerste onderzoeken naar het effect vam selectieve decontaminatie bij kunstmatig beademde patiënten tonen een vermindering van het aantal infecties. Echter, bij deze eerste onderzoeken ontbrak een prospectieve controle. De resultaten werden vergeleken met de incidentie van infecties in historische controlegroepen. Voorts bevatten vrijwel alle tot nu toe onderzochte regimes tobramycine. Dit is duur en kan bovendien - met name bij patiënten met gestoorde nierfunctic - leiden tot toxiciteit ten gevolge van tobramycine resorptie.

\section{Opzet van het onderzoek}

Dit proefschrift beschrijft een prospectief gerandomiseerd onderzoek naar het effect van een nieuw regime van selectieve decontaminatie op de incidentie van lagere luchtweginfecties bij patiënten die langdurig (gedurende tenminste vijf dagen) kunstmatig werden beademd.

Bij opname werden de patiënten willekeurig verdeeld over drie groepen. Patiënten in beide controle groepen I $(n=18)$ en II $(n=21)$ ontvingen geen antibiotische profylaxe; antibiotica werden uitsluitend voorgeschreven als er sprake was van een infectie. In groep I werden infecties behandeld met antibiotica die de anaerobe flora van de tractus digestivus (en dus de microbiële kolonisatieweerstand) verstoren, terwijl in groep II uitsluitend middelen werden gebruikt zonder invloed op de microbiële kolonisatieweerstand. Het doel van dit deel van de studie was, de verschillen in de invloed van antibiotica uit deze twee categorieën op de frequentie van kolonisatie en infectie te bepalen.

Bij patiënten in groep III $(n=17)$ werd van opname tot detubatie een regime van selectieve decontaminatie toegepast. Het regime bestond uit norfloxacin $50 \mathrm{mg}$, polymyxine E $200 \mathrm{mg}$ en amfotericine B $500 \mathrm{mg}$, vier mal daags toegediend via de maagsonde. Een mondpasta die dezelfde middelen bevatte (elk in een concentratie van $2 \%$ ) werd vier maal daags in de mond aangebracht. Patiënten in groep III kregen voorts systemische antibiotische profylaxe (cefotaxime 3 dd $500 \mathrm{mg}$ i. . ), maar dit alleen gedurende de eerste vijf dagen.

\section{Resultaten}

Bij opname was de oropharynx vaak gekoloniseerd met commensale micro-organismen en, zij het minder frequent, met Gram-negatieve bacillen. In beide controlegroepen bleef deze kolonisatie niet alleen bestaan, zij gaf bovendien frequent aanleiding tot infecties van de lagere luchtwegen (die zich vaak al manifesteerden gedurende de cerste dagen na opname). In groep III werden alle commensale micro-organismen en Gram-negatieve bacillen uit de oropharynx geëlimineerd en werd vroege infectie van de lagere luchtwegen volledig voorkómen. 
Patiënten in beide controlegroepen verwierven tijdens opname frequent nieuwe micro-organismen - vooral Gram-negatieve bacillen - in de oropharynx zowel als in de maag. Drieèntachtig procent van de patiênten in groep \ en $90 \%$ van de patiënten in groep II verwierven tenminste één nieuw micro-organisme in de oropharynx gedurende het verblijf op de intensive care. Nieuwe microbiële kolonisatie van de maaginhoud kwam voor bij $94 \%$ van de patiënten in groep I en bij $90 \%$ van de patiënten in groep II. In groep III voork wam selectieve decontaminatie de acquisitie van nieuwe micro-organismen in maag en oropharynx vrijwel volledig (Hoofdstuk IV).

Het toedienen van antibiotica (in groep I) die de microbiële kolonisatieweerstand verstoren, leidde tot een stijging van de concentratie Gram-negatieve bacillen in oropharynx en maag. Het gebruik van middelen zonder invloed op de kolonisatieweerstand in groep II leidde niet tot veranderingen in de concentraties Gram-negatieve bacillen. Desondanks was er geen significant verschil tussen groep I en II voor wat betreft de incidentie van infecties van de lagere luchtwegen: in groep I kregen 14 patiënten ( $78 \%$ ) tesamen 25 lagere luchtweginfecties, terwijl 13 patiënten $(62 \%)$ in groep II in totaal 22 infecties kregen.

De meeste infecties van de lagere luchtwegen in beide controlegroepen werden veroorzaakt door Gram-negatieve bacillen. In de etiologie van de wroege luchtweginfecties (optredend gedurende de eerste dagen van beademing), speelden micro-organismen die als commensaal in de oropharynx voorkomen eveneens een belangrijke rol.

In beide controlegroepen speelde kolonisatie van oropharynx en maaginhoud een sleutelrol in de pathogenese van infecties van de lagere luchtwegen: meer dan $90 \%$ van de luchtweginfecties in deze beide groepen werd voorafgegaan door kolonisatie van oropharynx, maaginhoud of beide met hetzelfde micro-organisme. De toepassing van selectieve decontaminatie in combinatie met systemisch cefotaxime leidde tot een significante reductie van de incidentie van lagere luchtweginfecties. Slechts één patiënt $(6 \%)$ in groep III kreeg een lagere luchtweginfectie tijdens opname. Deze infectie werd niet voorafgegaan door kolonisatie van matginhoud of oropharynx met het desbetreffende micro-organisme (Hoofdstuk V).

Het in deze studie gebruikte regime van selectieve decontaminatie in combinatie met systemische antibiotische profylaxe leidde tot een daling van de kosten van antibiotische therapie die meer dan opwoog tegen de kosten van het regime.

Hoewel de kosten van het gebruikelijke bacteriologisch onderzoek het lagsst waren in groep III, waren de totale kosten van bacteriologisch onderzoek in deze groep hoger dan in beide controlegroepen. Dit werd veroorzaakt door de kosten van de bewakingskweken, die noodzakelijk zijn om hel effect van selectieve decontaminatie te vervolgen. Aangezien deze kweken meestal negatief uitvallen, zouden de tarieven aangepast kunnen worden, zodat selectieve decontaminatic 
ook in dit opzicht voordeliger zou worden. Bovendien kan de frequentie van de bewakingsk weken worden gereduceerd.

\section{Discussie}

Het gebruik wan antibiotica die de autochtone anaerobe flora van de tractus digestivus - en dus de microbiële kolonisatieweerstand - verstoren, leidt bij ernstig zieke patiënten tot een stijging van de concentraties van Gram-negatieve bacillen in oropharynx en maag. Dit vergroot de kans op lagere luchtweginfecties. Toch leidde eliminatie van dit risico in groep II slechts tot een geringe reductie van de incidentie van lagere luchtweginfecties. De verklaring hiervoor is waarschijnlijk gelegen in het feit dat, bij deze ernstig zieke patiënten, de fysiologische kolonisatieweerstand (slikken, hoesten, speekselvloed etc.) ook verstoord is. Deze verstoring kan worden veroorzaakt door de ziekte, alsook door intubatie en ander medisch handelen.

Bij patiënten die minder ernstig ziek zijn kan verwacht worden dat beperking van het arsenaal antibiotica tot middelen die de kolonisatieweerstand niet verstoren zal leiden tot preventie van kolonisatie en infectie met Gram-negatieve bacillen. Bij de door ons onderzochte categorie patiënten was dit niet het geval, hetgeen verdergaande profylactische maatregelen noodzakelijk maakt.

Selectieve decontaminatie in combinatie met kortdurende systemische toediening van cefotaxime zorgde ervoor dat micro-organismen die de oropharynx en de lagere luchtwegen reeds koloniseerden werden geëlimineerd en voorkwam bovendien acquisitie van nieuwe micro-organismen in oropharynx en maag van beademde patiënten. Hiermede werden de twee belangrijkste bronnen van bacteriën die lagere luchtweginfecties veroorzaken geëlimineerd, hetgeen resulteerde in een significante reductie van de incidentie van op de intensive care verworven lagere luchtweginfecties.

Selectieve decontaminatie elimineert niet alleen Gram-negatieve bacillen uit het bovenste deel van de tractus digestivus, doch - bij intacte peristaltiek - ook uit het ondersle deel van de tractus digestivus en de faeces. De voordelen hiervan zijn: de eliminatie van een belangrijke bron van infectie en kruisinfectie, alsook van een bron van endotoxaemie. Verder verdwijnen met de eliminatie van Gram-negatieve bacillen uit oropharynx en het lagere deel van de tractus digestivus twee belangrijke plaatsen waar resistentie tegen antibiotica zich kan ontwikkelen.

\section{Conclusies}

Het gebruik van antibiotica die de kolonisatieweerstand verstoren leidt tot een stijging van de concentraties Gram-negatieve bacillen in oropharynx en maag van 
enstig zieke patiënten. Het gebruik van deze antibiotica dient bij gehospitaliseerde patiënten waar mogelijk te worden vermeden.

Selectieve decontaminatie met norfloxacin, polymyxine $\mathrm{E}$ en amfotericine B in combinatie met kortdurende systemische cefotaxime profylaxe bleek een veilige. effectieve en kostendekkende manier om lagere luchtweginfecties bij langdurig beademde patienten te voorkomen. Bij patiënten waarvan wordt verwacht dat zij langer dan enkele dagen kunstmatig zullen moeten worden beademd, is vanaf de start van de beademing, de toepassing van selectieve decontaminatie in combinatie met kortdurende systematische profylaxe geindiceerd. 



\section{Dankwoord}

Aan het eind van dit proefschrift wil ik iedereen die aan de totstandkoming ervan op welke wijze dan ook heeft bijgedragen hartelijk danken.

Enkele personen wil ik met name noemen:

Allereerst wijlen drs.H.B.Benraad, mijn oud-opleider, die mij anzette tot het verrichten van wetenschappelijk onderzoek.

Daarnaast mijn huidige opleider dr. Roy Go, voor de enthousiaste wijze waarop hij het onderzoek volgde en voor de moeite die hij zich getroostte om steeds weer het opleidingsschema aan te passen als mijn proefschrift weer meer tijd opeiste.

Roelof van Dalen, stafarts van de afdeling intensieve zorg van het St.Radboud Ziekenhuis, liet mij profiteren van zijn ervaring en nauwkeurigheid bij het opzetten van ons onderzoek en bij het vergaren en verwerken van de gegevens.

Dr.Henk Clasener, arts-microbioloog in het Canisius-Wilhelmina Ziekenhuis, was zeer behulpzaam bij het zoeken van literatuur. Daarnaast was zijn commentaar op de tekst van grote invloed op het uiteindelijke resultaat. Bovendien plaatste hij alle punten en komma"s in dit proefschrift.

Prof.dr.Cees van Boven, mijn promotor, dank ik voor de wijze waarop hij ons onderzoek, waarbij hij pas in een wat later stadium werd betrokken, meer diepgang gaf. Vooral wardeer ik dat hij hierbij de grens van wat mogelijk en onmogelijk was nooit uit het oog verloor. Ook zijn steun bij "de laatste loodjes" was voor mijerg belangrijk.

Hans Vollaard, ziekenhuisapotheker in het Canisius-Wilhelmina Ziekenhuis, op wiens ideeën het gebruikte schema voor SDD is gebaseerd, bracht mij steeds met veel enthousiasme op de hoogte van de nieuwste ontwikkelingen op het gebied van antibiotica en kolonisatieweerstand.

Ir. Henk van Lier, statisticus bij de Mathematisch Statistische Adviesafdeling van de Katholieke Universiteit Nijmegen, was vanaf een vroeg stadium bij ons onderzoek betrokken en gaf waardevolle adviezen, zowel op zijn vakgebied als ver daarbuiten.

Dr.Jan Festen, longarts op de afdeling pulmonologie van het St. Radboud Ziekenhuis, beoordeelde met veel geduld meer dan 1000 thoraxfoto's en beoordeclde "blind" of er al dan niet sprake was van een infeclie van de onderste luchtwegen. Door dit monnikkenwerk vergrootte hij de waarde van ons onderzoek emorm.

Prof.dr.Frans Rutten gaf wardevolle adviezen woor het hoofdstuk over de kosten. Prof dr.P.G. Knipschild en de overige leden van de beoordelingscommissie dank ik voor hun opmerkingen, die resulteerden in enkele belangrijke aanvullingen.

Stafleden en arts-assistenten van de afdeling intensieve zorg van het St. Radboud Ziekenhuis (Hoofd: Dr. Jules Gimbrère) wil ik danken voor het feit dat zij mij niet alleen in staat stelden op hun afdeling onderzoek to verrichten, matar hicr bovendien nog met hart en ziel aan meewerkten. 
Het verplegend personeel van de afdelingen $\mathrm{H} 20, \mathrm{H} 30, \mathrm{H} 31$ - 32 en $\mathrm{N} 12$ van het St.Radboud Ziekenhuis werkte met steeds groter wordend enthousiasme mee aan de uitvoering van het onderzoeksprotocol.

Staf en medewerkers van de laboratoria voor microbiologie van het St. Radboud Ziekenhuis en het Canisius-Wilhelmina Ziekenhuis dank ik hartelijk voor het verrichten van al het bacteriologisch onderzoek. In het bijzonder wil ik dr. Harry Muytjens en dr.Jan-Arend van Griethuysen danken voor de moeite die zij zich hebben getroost de samenwerking tussen beide laboratoria tot stand te brengen en vooral in stand te houden.

Suzy de Swart corrigeerde nauwgezet en met veel enthousiasme de engelse tekst. De figuur in hoofdstuk II werd vervaardigd door mijn vader, J.H.H.Aerdts, en Mw. Aria Meyer. De overige figuren door Jacques Mertens.

Edith Eyssen, secretaresse van de maatschap internisten van het Canisius-Wilhelmina Ziekenhuis, stond altijd klaar als ik secretariële hulp nodig had.

Dr. Rick van Saene, Senior Lecturer, Department of Microbiology, University of Liverpool, volgde ons onderzoek op enige afstand, doch met grote belangstelling en voorzag mij van literatuur en goede raad wanneer dat nodig was.

Mijn collega"s arts-assistenten interne geneeskunde in het Canisius-Withelmina Ziekenhuis dank ik voor de wijze waarop zij, vrijwel zonder morren, mijn werk overnamen als ik weer eens voor "mijn boekje" bezig was. Jullie collegialiteit en interesse was altijd bijzonder stimulerend.

Mijn opleiders, de leden van de interne maatschap in het Canisius-Wilhelmina Ziekenhuis, dank ik voor hun belangstelling en voor de gelegenheid die zij mij boden om, tijdens mijn opleiding, wetenschappelijk onderzoek te verrichten en te voltooien.

Zonder de medewerking van bovengenoemden zou dit proefschrift er nooit gekomen zijn.

Tenslotte wil ik Willemijn, Tim en vooral Piep bedanken voor hun steun en voor de offers die zij gebracht hebben voor het tot stand komen van dit boekje. Pas nu begrijp ik waarom proefschriften altijd aan wrouw en kinderen worden opgedragen. 


\section{Currilicum Vitae}

Name: $\quad$ Stanislaus Jacobus Antonius Aerdts

Born: $\quad$ May 27th 1956 in Venlo, The Netherlands.

1968-1974: Atheneum B, Rijksscholengemeenschap, Venlo.

1974-1981: Medical School, State University, Utrecht.

1981-1983: Resident in Surgery, Gynecology and Obstetrics, Hospital Salem, Ermelo, The Netherlands.

1983-1989: Resident in Internal Medicine, Canisius-Wilhelmina Hospital (Head: H.B.Benraad (deceased), successively dr.I.H.Go), Nijmegen, The Netherlands. 